\title{
خريطة الجدارات التدرييية الخاصة بالمهارات الحياتية \\ لدى أخصائي المعلومات يجامعة المنوفية: \\ دراسة للواقع وتخطيط للمستقيل
}

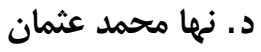 \\ أستاذ مساعد بقسم المكتبات والمعلومات \\ كلية الآداب -جامعة المنوفية \\ braanoha@yahoo.com
}

المستخلص:

تهدف هذه الدراسة إلى معرفة خريطة الجدارات التدريبية الخاصة بالمهارات الحياتية لدى أخصائي المعلومات بجامعة

المنوفية، حيث طبقت الدراسة على 175 أخصائي معلومات، وقد تم استخدام المنهج الميداني الوصفي التحليلي كونه أنسب

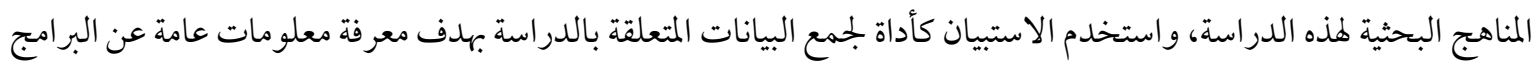
التدريبية التى حصلت عليها عينة الدراسة من قبل، وأهداف البرامج التدريبية التى حصلت عليها عينة الدراسة ومزاياها، ومدى بلئي الإفادة من البرامج التدريبة التى تم الخصول عليها، والاحتياجات التدريبية المستقبلية الخاصة بتنمية الموارد البشرية، وفى النهاية تم وضع خطة واقعية مستقبلية بناء على تحديد الاحتياجات التدريبية وخريطة الجدارات التدريبية لعينة الدراسة، ومن أهم نتائج الدراسة أن 163 أخصائي معلومات بنسبة 93.1٪ أقروا بأن الدورات التدريبية الخاصة بتنمية الموارد البشرية تسهم في رفع

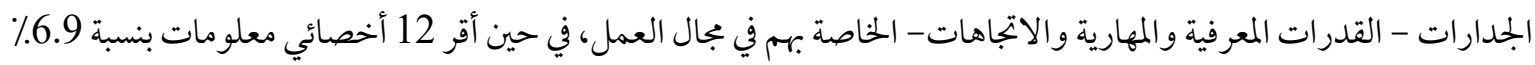
بأن الدورات التدريبية الخاصة بتنمية الموارد البشرية لا تسهم في رفع الجدارات - القدرات المعرفية والمهارية والاتجاهات- الخاصة

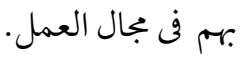

الكلمات المفتاحية: خريطة الجدارات التدريبية؛ المهارات الحياتية؛ الاحتياجات التدريبية؛ أخصائي المعلومات ؛ تنمية الموارد

البشرية ؛ البرنامج التدريبي.

تاريخ القبول: 04 أكتوبر 2020
تاريخ الاستلام: 04 سبتمبر 2020

المجلة العلمية للمكتبات والوثائق والمعلومات؛ مج 4، ع9 (يناير 2022) 
تحظى تنمية الموارد البشرية وتنمية وتطوير المهارات الحياتية بأهمية بالغة في العصر الحاضرو بخاصة في مراحل التطور

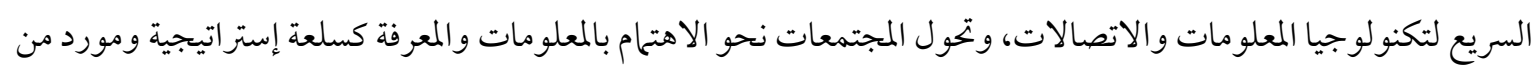
موارد الدخل القومي، فالموارد البشرية هي رأس المال الفكري الذي يعد أثمن أصول المؤسسات، والثروة المستدامة الوحيدة التي تبقى عندما تزول باقي الثروات. لا يمكن تصور مؤسسة متقدمة تعمل بكفاءة عالية ما لم تكن قد اهتمت بتدريب موظفيها وتحسين وزيادة كفاءتهم؛ وذلك لأن التدريب هو أحد المقومات الأساسية التي تساعد على تزويد الموظفين بالمعارف والمهارات والاتجاهات الإيجابية التي تسهم في رفع مستوى أدائهم الوظيفي، ومن ثَمَّ التأثير الجِيد على أداء المؤسسة. وقد شهدت السنوات الأخيرة اهتماما كبيرا بالتدريب والتأهيل في رفع كفاءة الموظفين من قبل مختلف المؤسسات ومختلف أنواع المكتبات، وأصبح من أساسيات تقديم الخدمات المعلوماتية وخدمة المستفيدين فى محيط أية مكتبة أو مؤسسة معلوماتية هو تنمية الموارد البشرية بهذا الكيان المتنامى؛ لمساعدته على تحقيق رسالة المكتبة وتقديم خدمات بأعلى مستوى من الكفاءة والفاعلية، وتحقيق التواصل الفعال مع المستفيدين؛ من أجل تقديم خدمة متميزة فى ظل ضغوط العمل والإحباطات المتنامية والصعوبات التى تواجه الجميع · وتأسيسًا على ما تقدم كان الر أي ضرورة أن تتناول هذ الدراسة موضوع الاحتياجات التدريبية الخاصة بالمهارات الحياتية لدى أخصائي المعلومات فى المكتبات الأكاديمية بجامعة المنوفية .

\section{مشكلة الدراسة:}

المورد البشري في المؤسسات وبخاصة المكتبات من أهم الموارد ؛فهو يمثل المحرك الأساس في عجلة التنمية المعرفية داخلها، ومن ثم تنمية هذا المورد البشري أصبح أمرا ملحا، فأخصائي المعلومات له دور حاسم في قيام المكتبة وبقائها ونموها و المساهمة في تطويرها وتحديد مكانتها في محيطها الذي يتميز بالتطور المستمر، ويخاصة مع التقدم التكنولوجي في شتى المجالات، ومن ثم يمكن حصر مشكلة الدراسة في التساؤلات الآتية:

- ما درجة إفادة أخصائي المعلومات في المكتبات الأكاديمية بجامعة المنوفية من البرامج التدريبية التى قدمت لهم

من قبل؟

ما المعوقات التى حالت دون الإفادة من البرامج التدريبية التى حصلت عليها عينة الدراسة من قبل ؟

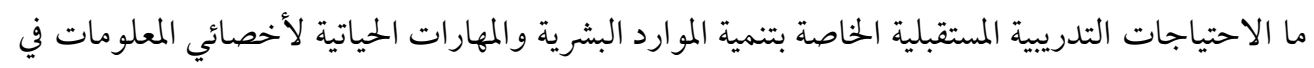

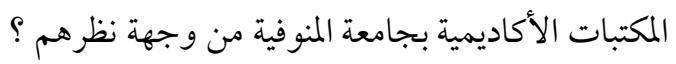

\section{أهميهية الدراسة ومبرارتها:}

تأتي أهمية هذه الدراسة - من وجهة نظر البحث- من أهمية التدريب الخاص بتنمية الموارد البشرية لأخصائي المعلومات

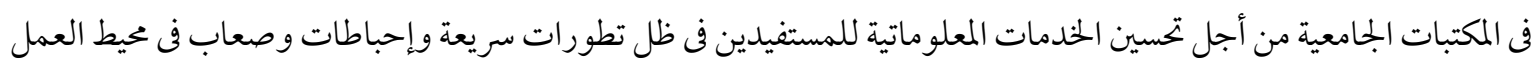


وخارجه، وكذلك مساعدة التدريب للمكتبات في تسويق خدماتها المقدمة للمستفيدين بشكل لائق، وتطبيق معايير الجودة

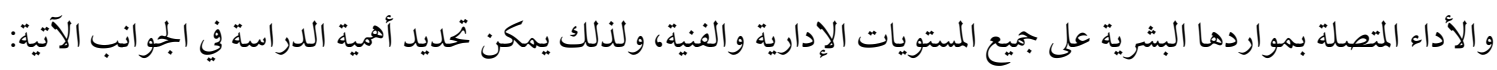
- الجانب النظري: يتمثل في إثراء الرصيد المعرفي الخاص بتخصص المكتبات والمعلومات بدراسة في بجال التدريب وتنمية

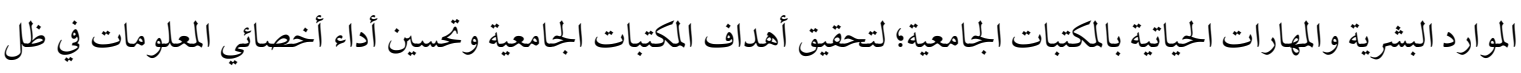

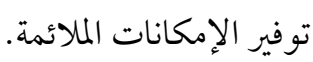

- الجانب التطبيقي: يكمن في إظهار مدى وعي أخصائي المعلومات بالمكتبات الجامعية بأهمية الخضوع إلى دورات تدريبية

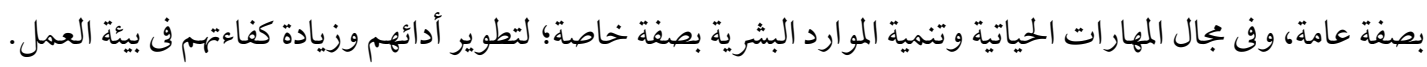

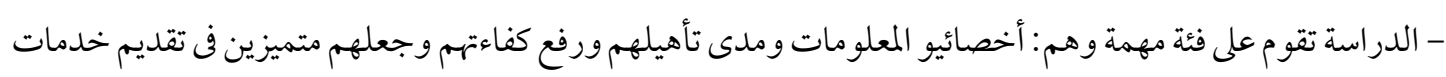
المعلو مات.

\section{أهداف الدراسة:}

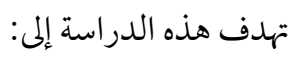

- استبطان مدى أهمية تحديد الاحتياجات التدريبية الخاصة بالمهارات الحياتية لدى أخصائي المعلومات في تقديم

$$
\text { خدمات متميزة لفئات المستفدين من المكتبات الأكاديمية. }
$$

- - متديد البرامج الندريبة التى حصل عليها أخصائي المعلومات في المكتبات الأكاديمية بجامعة المنوفية من

- - تحليل أهداف البرامج التدريبية التى حصل عليها أخصائي المعلومات في المكتبات الأكاديمية بجامعة المنوفية

$$
\text { ومز اياها. }
$$

دراسة مدى الإفادة من البرامج التدريبية التى حصل عليها أخصائي المعلومات في المكتبات الأكاديمية بجامعة

المنوفية.

- - - - ماستبطان الخطط التدريبية المكتوبة والمعلنة لتدريب وتطوير أخصائي المعلومات فى المكتبات الأكاديمية بجامعة

المنوفية.

- - متديد الاحتياجات الثدريبة المستقبلية الخاصة بأخصائي المعلومات في المكتبات الأكاديمية بجامعة المنوفية والخاصة بالمهارات الحياتية وبتنمية الموارد البشرية.

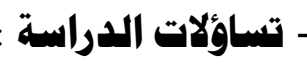

$$
\text { ولتحقيق الأهداف السابقة تحاول الدراسة الإجابة عن التساؤلات الآتية : }
$$

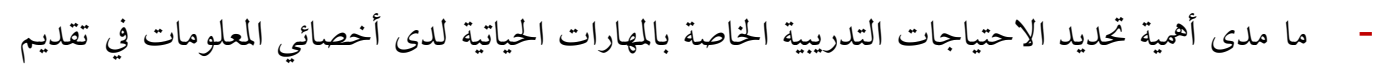

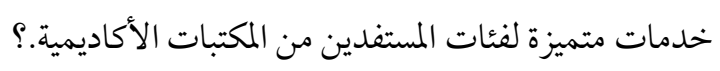

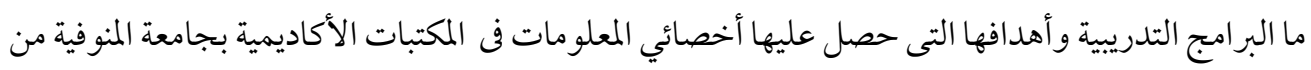


- ما مدى الإفادة من البرامج التدريبية التى حصل عليها أخصائي المعلومات فى المكتبات الأكاديمية بجامعة

المنوفية

- هل توجد خطط تدريبية وواضحة ومكتوبة لتدريب وتطوير أخصائي المعلومات في المكتبات الأكاديمية

بجامعة المنوفية

ما الاحتياجات التدريبية المستقبلية الخاصة بأخصائي المعلومات فى المكتبات الأكاديمية بجامعة المنوفية والخاصة

$$
\text { بالمهارات الحياتية وبتنمية الموارد البشرية؟ }
$$

\section{منهج الدراسة وأدواته:}

تم الاعتماد فى هذه الدراسة على المنهج الميدانى الوصفى التحليلى الذى يعد مناسبا لهذه الدراسة التى تهتم بتقصى الآراء، ومعرفة الاتجاهات، وذلك بهدف تحديد مشكلة الدراسة وتحليلها، ودارسة واقع ظاهرة معاصرة؛ وهي التعرف على الاحتياجات التدريبة الخاصة بالمهارات الحياتية لدى أخصائي المعلومات فى المكتبات الأكاديمية بجامعة المنوفية.

أدوات جمع البيانات:

تعد المقابلة من الوسائل المهمة للحصول على البيانات وتجميع المادة العلمية حول موضوع الدراسة، وقد استعانت البحث بالمقابلة المقنتة وهى (التى تحدد فيها الأسئلة من قبل وتوجه للمبحوث بالصياغة نفسها وبالترتيب نفسه) ، مع أخصائي المعلومات فى المكتبات الأكاديمية بجامعة المنوفية.

\section{الاستبيان :}

لأغر اض جمع المعلومات اللازمة للدراسة وتمشيا مع طبيعة البحث فقد تم استخدام أداة الاستبيان وتم توزيعه على عينة الدراسة، وقد تكون من 17 سؤالا تم توزيعها على خمسة محاور أساسية وهى: (المعلومات الشخصية، ومعلومات عامة عن البرامج التدريبية التى تم الحصول عليها من قبل، وأهداف البرامج التدريبية التى تم الحصول عليها ومزاياها، ومدى الإفادة من البرامج التدريبية التى تم الخصول عليها، والاحتياجات التدريبية المستقبلية الخاصة بتنمية الموارد البشرية). وقد تم استخدام (مقياس ليكرت الثلاثى) فى إعداد الاستبيان، وهو نمط يصلح في دراسة الآراء والاتجاهات ويطلب من المبحوث وضع علامة تمثل رأيه على واحدة من الاختيارات التالية: (موافق - غير متأكد - معارض)

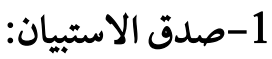

للتأكد من صدق الاستبيان والمحتوى وسلامة البناء وارتباطه بأغر اض الدراسة ومدى قدرته في قياس ما أعد من أجله فى الدراسة، تم إجراء التحكيم له عن طريق عرض الاستبيان على خمس أساتذة في تخصص المكتبات والمعلومات، وأستاذ فى 
تخصص علم الاجتماع(1)، لمعرفة رأيهم فيما إذا كان الاستبيان يقيس ما وضع من أجله، من حيث شمولية الأسئلة ووضو حها،

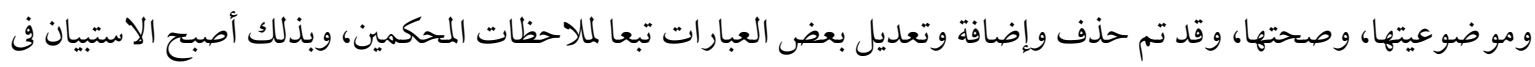
صورته النهائية صالحا لتحقيق أهداف الدراسة.

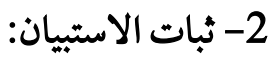

تم استخدام أسلوب إعادة الاختبار حيث تم جمع البيانات من عينة عشوائية تمثل مجتمع الدراسة، وعددها عشر

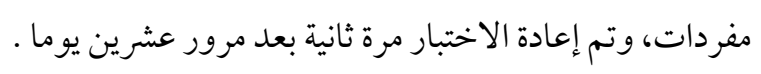

ومعادلنه = عدد الأخطاء x عدد المبحوثين x عدد الأسئلة

وبلغت نسبة معامل القدرة على الاسترجاع 0,82 وهذا يدل على ثبات الاستبيان.

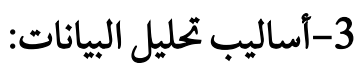

تم استخدام حزمة المجموعة الإحصائية للعلوم الاجتماعية ؛ (SPSS ) لعرض وتحليل بيانات الدارسة، وقد استُخدمت

النكرارات والنسب المئوية لعرض البيانات وتحليلها.

\section{4- المعالجة الإحصائية للبيانات:}

تم تفريخ الاستبيانات في جداول، ومعالجة البيانات إحصائيا باستخدام برنامج (SPSS) ويتميز هذا البرنامج بإمكانات

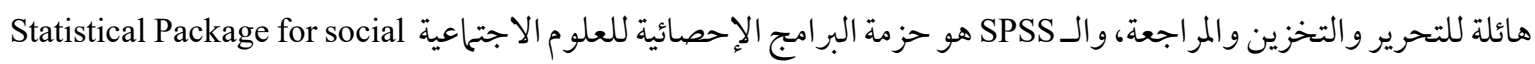

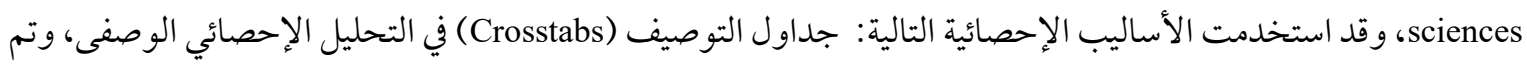

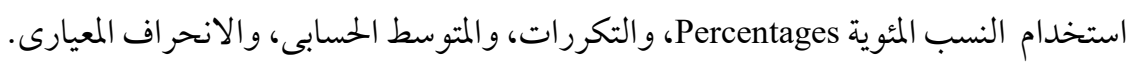

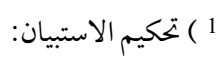

- الأستاذ الدكتور محمد أمحد باصقر (أستاذ علم المعلومات وعميد كلية العلوم الاجتاعية بجامعة أم القرى

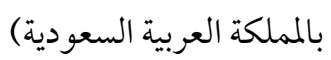

- الأستاذ الدكتور عبد الرشيد بن عبد العزيز حافظ (أستاذ علم المعلومات بجامعة الملك عبدالعزيز بجدة بالمملكة

$$
\text { العربية السعودية) }
$$

الأستاذ الدكتور أسامة القلش (أستاذ علم المكتبات والمعلومات بكلية الآداب جامعة القاهرة)

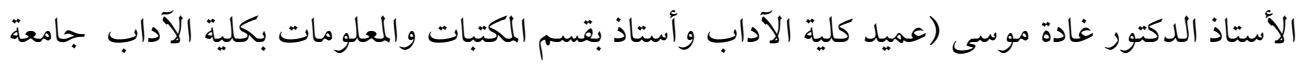

$$
\text { الإسكندرية) }
$$

والأستاذ الدكتور ميساء محروس (رئيس قسم المكتبات والمعلومات بكلية الآداب جامعة الإسكندرية).

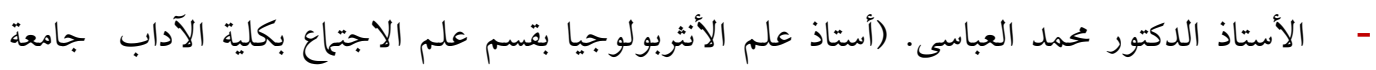

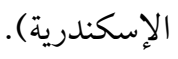




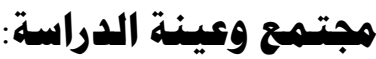

يتمثل مجتمع الدراسة في أخصائيي المعلومات في المكتبات الأكاديمية بجامعة المنوفية وقد بلغ عددهم 234 ما بين

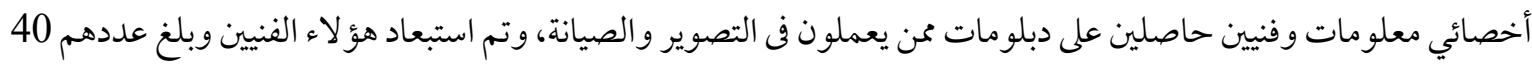

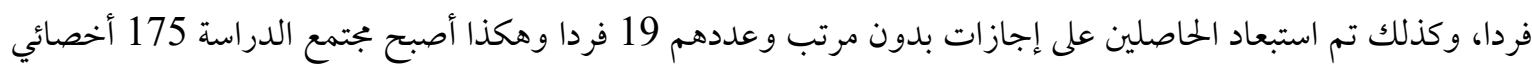

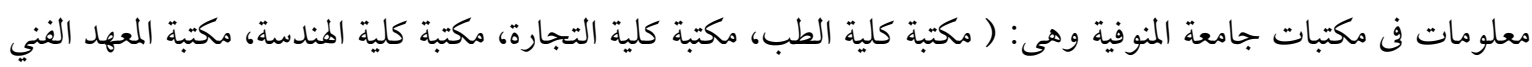

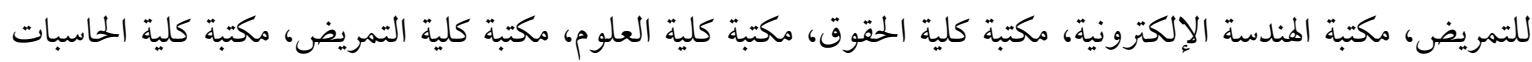

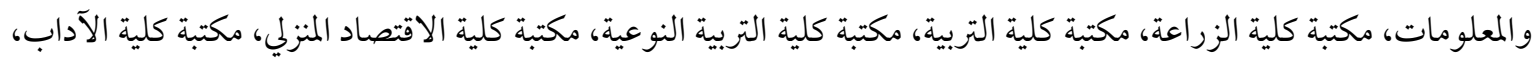

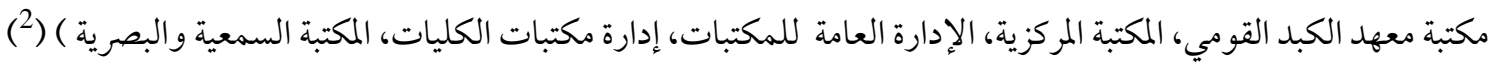
ويقصد بعينة الدراسة ججموعة الأفراد التى تجرى عليهم الدراسة وتنطبق عليهم خصائص العينة والتى تتطلبها الدراسة،

$$
\text { وتم اختيار عينة الدراسة بناء على الأسس الآتية : }
$$

1 - أسلوب العينة المسحية لمجتمع الدراسة؛ أي: لكل أخصائيي المعلومات في المكتبات المات الأكاديمية بجامعة المنوفية الماتية وعددها

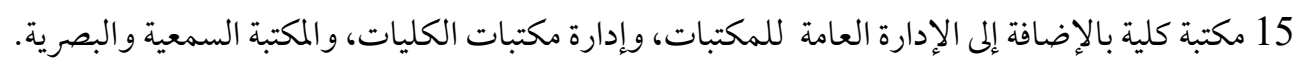

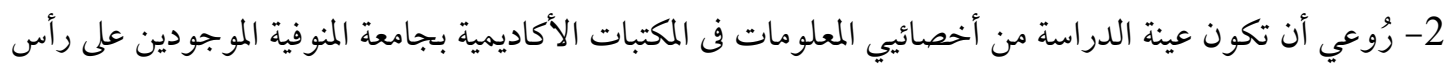

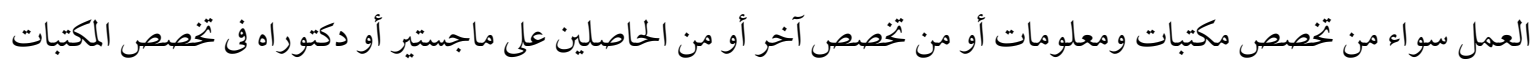
والمعلومات. 3- روعي أن تكون عينة الدراسة من أخصائيي المعلومات في المكتبات الأكاديمية بجامعة المنوفية والذين يعيشون في جميع

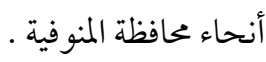

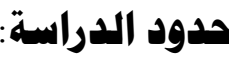

- الحدود الموضوعية: تشمل الدراسة الاحتياجات التدريبية الخاصة بالمهارات الحياتية لدى أخصائيي المعلومات فى

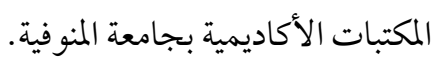
- الحدود المكانية: الدراسة تشمل أخصائيي المعلومات في المكتبات الأكاديمية بجامعة المنوفية.

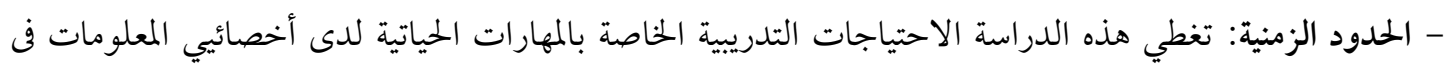

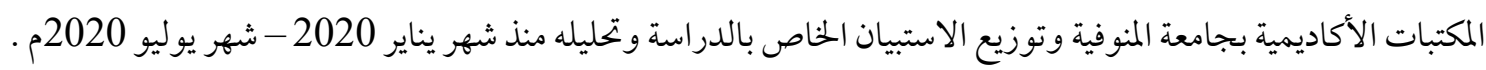

هصطات الدراسة: تنوعت وتعددت مصطلحات الدراسة، وكان من أبرزها ما يلى: 2 ) تم الاعتاد في تميع هذه الإحصائية على إحصائيات الإدارة العامة للمكتبات بجامعة المنوفية،وهذه الإحصائيات تغطى إلى شهر مارس2020م. 
- - مالمهارات الحياتية: وتعرف بأنها: "السلوكيات والمهارات الشخصية والاجتماعية اللازمة للأفراد للتعامل بثقة

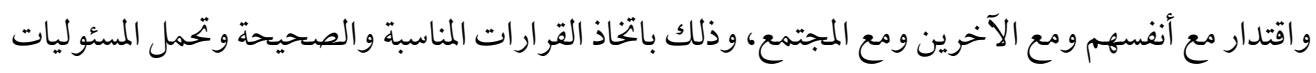

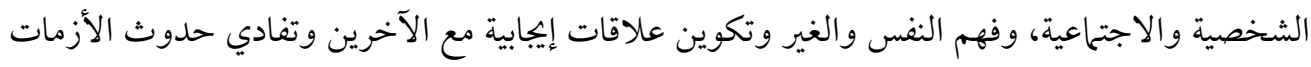
والقدرة على التفكير الابتكاري (المهارات الحياتية، 2015م). خريطة الجدارات : يقصد بها: "الإطار المرجعي للمقارنة بين المستوى الحلالي والمطلوب من جدات المبارية المارات الفرده،

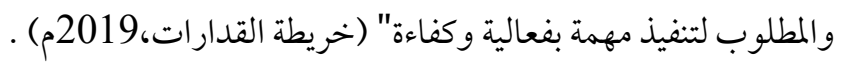

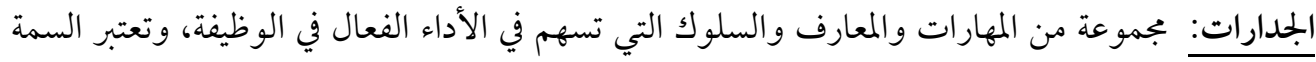

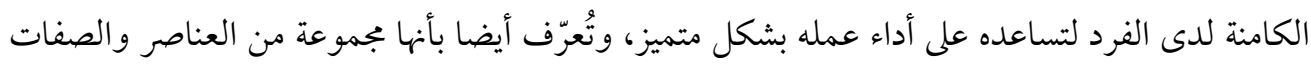

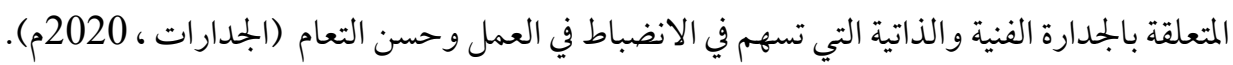

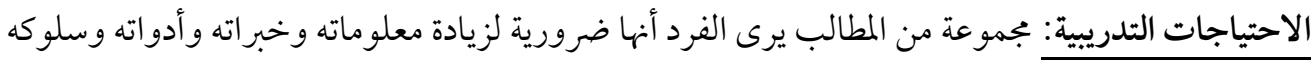

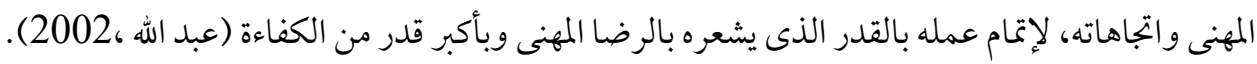

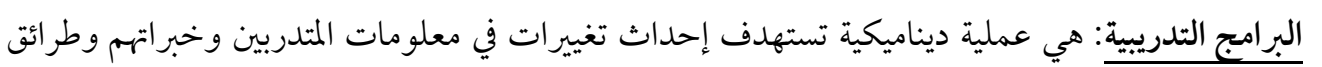

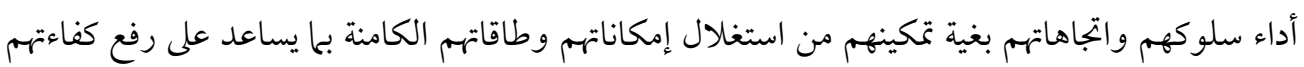

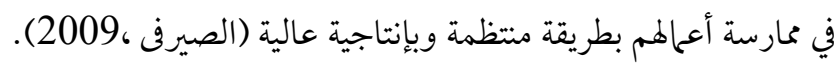

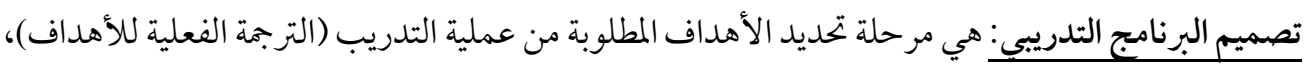

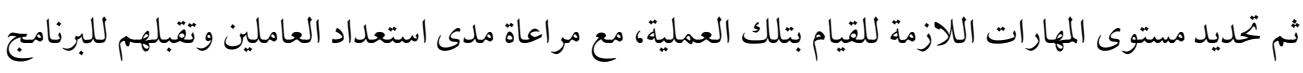

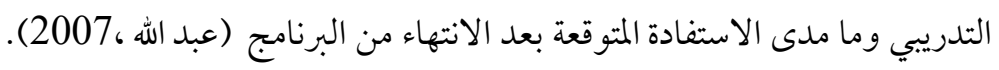
المثدربون: هم العناصر المستفيدة من التدريب والذين يجرى عليهم الثدريب.

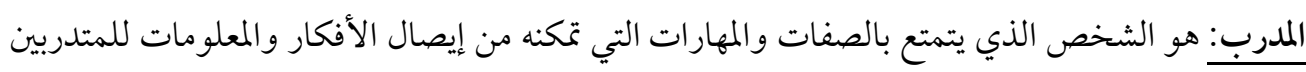

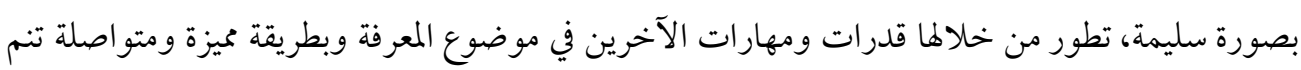
عن قدرات وخبرات يتمتع بها (بلال ، 2009).

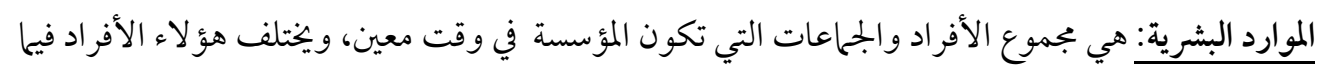

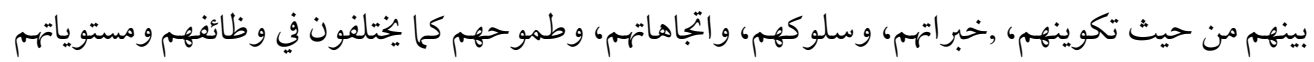

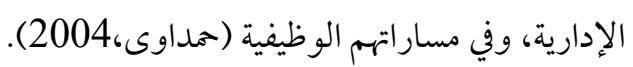

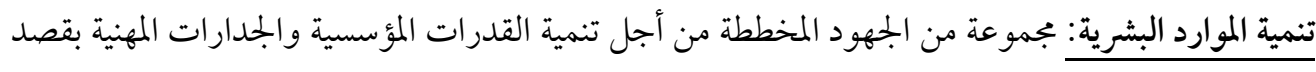

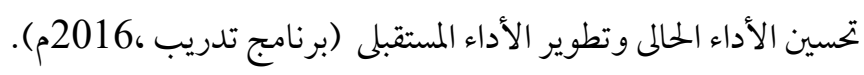

\section{الدراسات السابقة والمثيلة:}

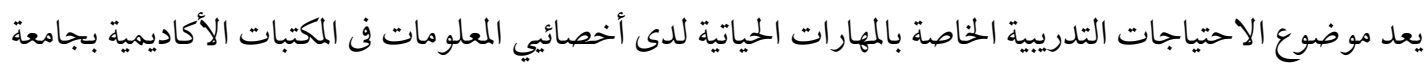

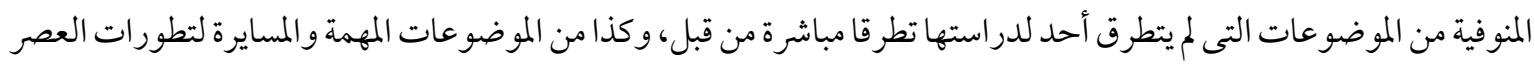

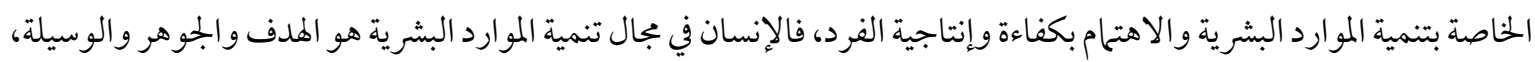


وسوف يتم استعراض الدراسات التى تم التوصل إليها ولها علاقة بجوانب الموضوع، وفق إطار تحليلى يحاول تحديد إطار كل

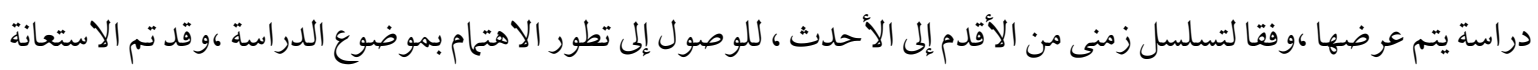

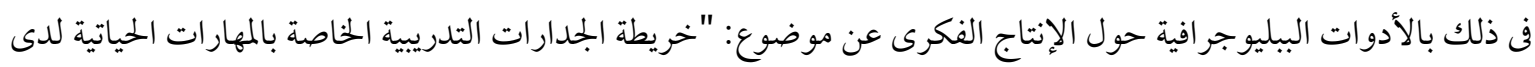

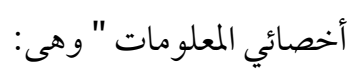
- - - مهرس اتحاد مكتبات الجامعات المصرية.

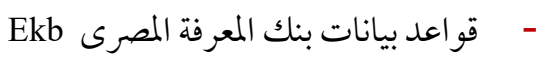

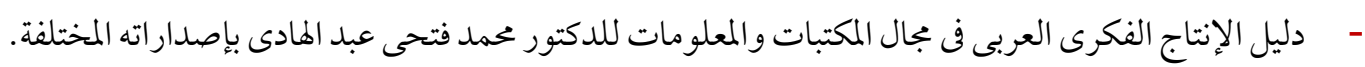

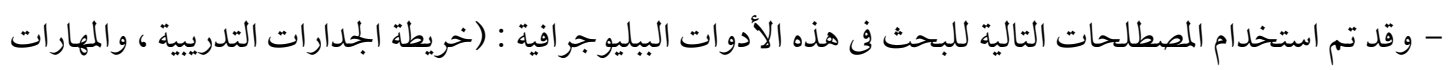

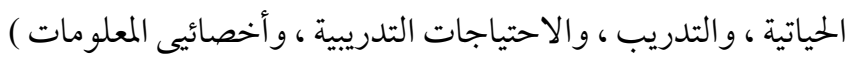

Training-. Training evaluation- Leadership- The job training needs Practices وفيما يلى سيتم استعر اض الدراسات السابقة والمثيلة التى تم التوصل لها :

أولا : الدراسات العربية:

هناك دراسة للباحث (الرويلي، 2000) تناولت أنواع وأهداف التدريب وهي: الأهداف التقليدية لتدريب الموظفين

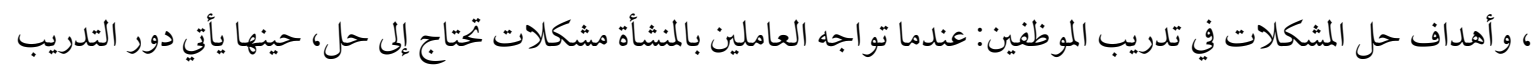

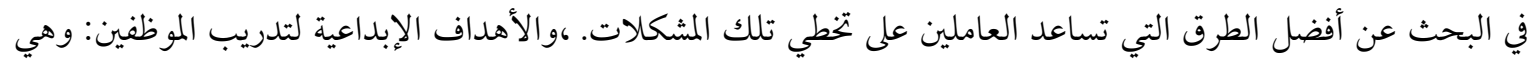

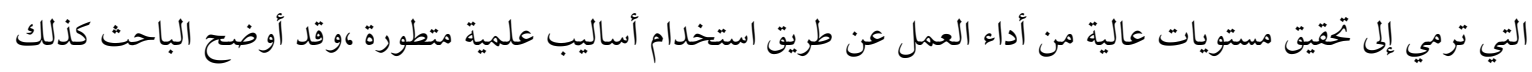
أهمية التدريب.

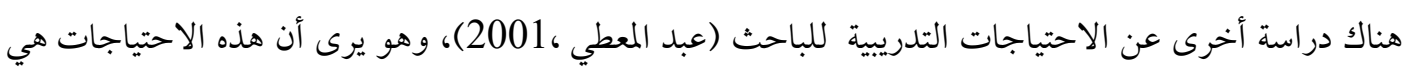

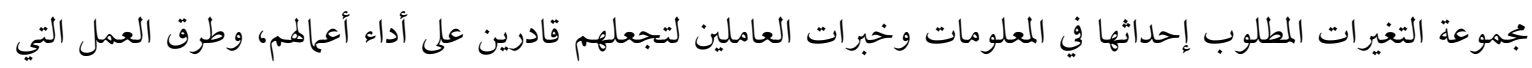

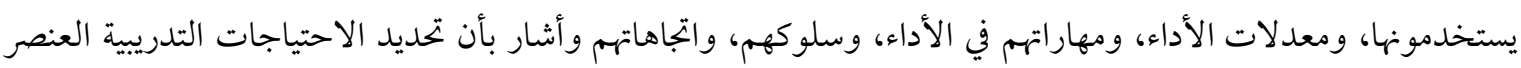

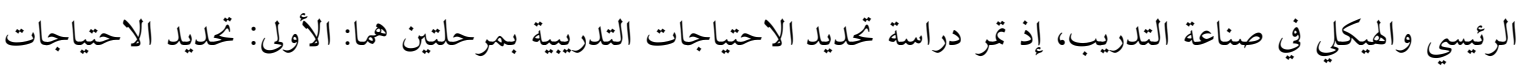

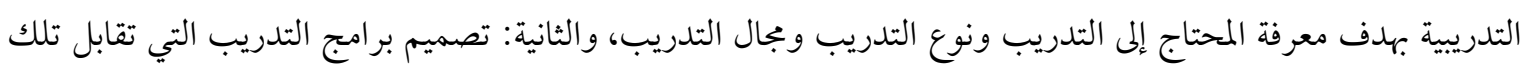

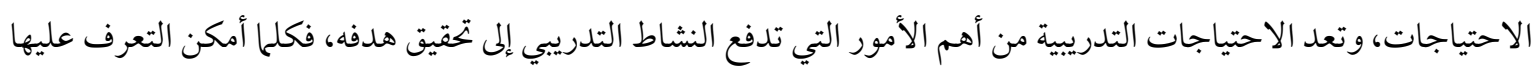

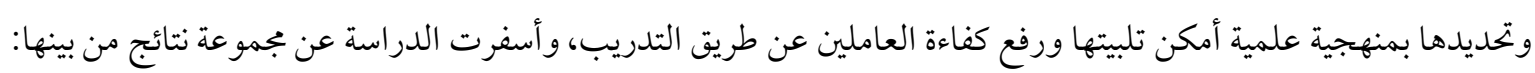

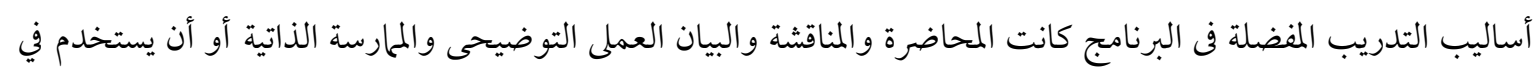
البرنامج مواد مطبوعة مزودة برسومات أو مشاهدة برامج تعلم ذاتي أو الجمعع بين كل الأساليب السابقة.

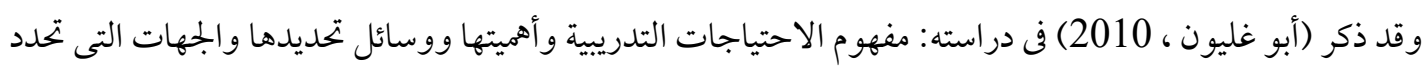

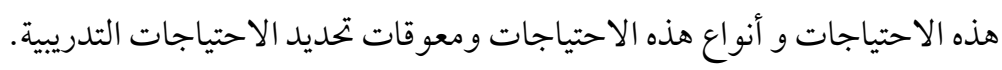




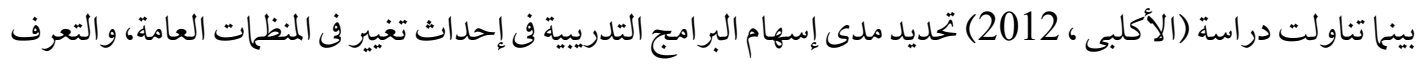

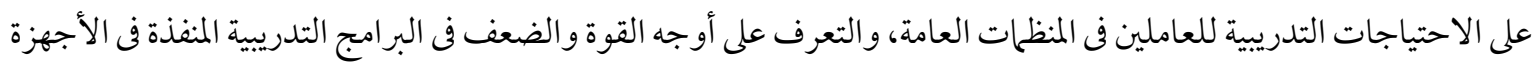
الحكومية. وتناولت دراسة (عمر ، 2013) دراسة أثر التدريب في تنمية الموارد البشرية في جامعة الإسكندرية كأحد أهم الجامعات المصرية، وأكثرها تأثيرا و إثراء للمجالات التعليمية المختلفة، وذلك من خلال بحث محاور العملية التدريبية بالجامعة والمتمثلة

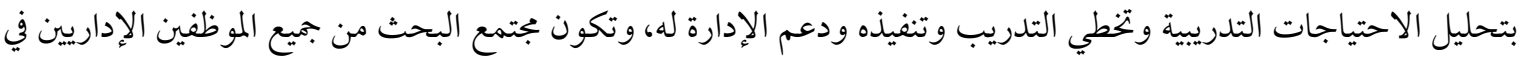

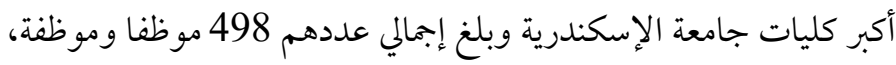

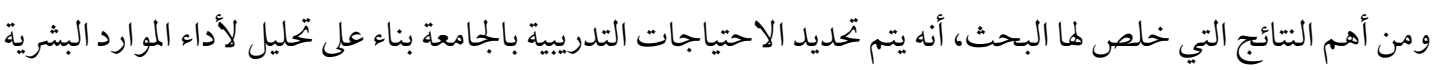

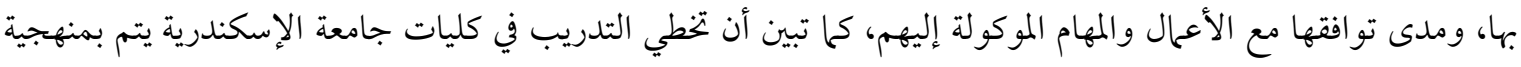

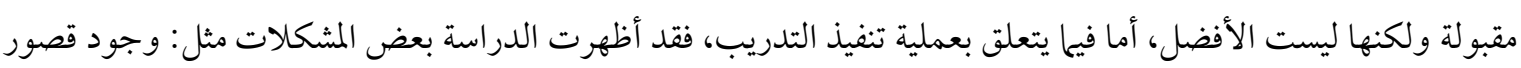

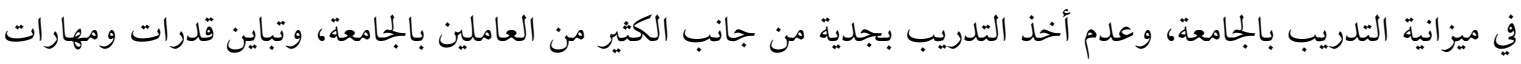

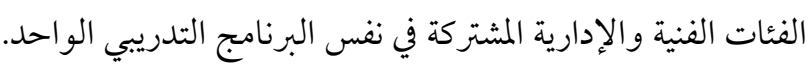
كما ذكرت (؟على ،2014) في رسالة الدكتوراه الخاصة بها أن هذه الدراسة تهدف إلى دراسة واقع تدريب العاملين في

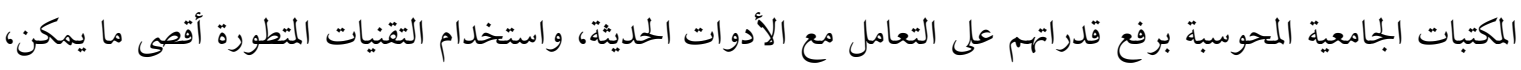

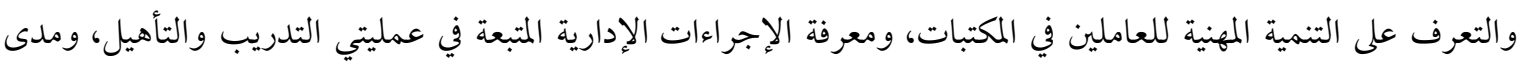
استخدام التقنيات المتطورة وتدريب العاملين عليها.

وقد ذكر كذلك (الحدراوى ،2015) في دراسته لمراحل تدريب الموارد البشرية ودورها في تحقيق الميزة الثنافسية المستدامة،

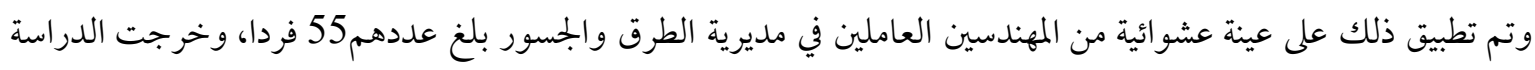

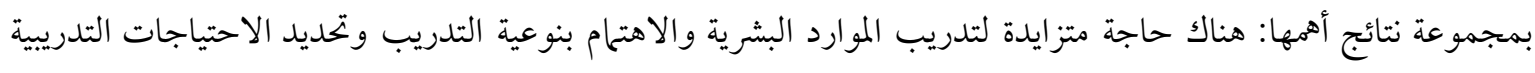
الفعلية، يزيد من مستوى كفاءة العاملين ومن ثم يمقق ميزة تنافسية مستدامة .

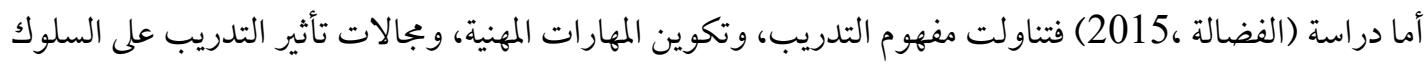

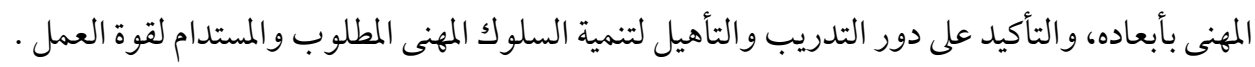

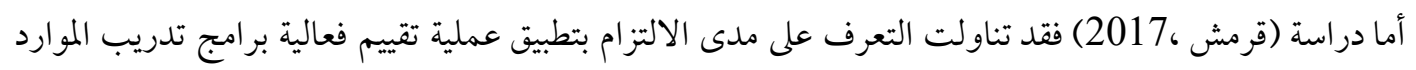

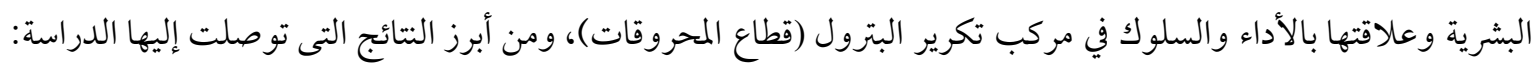

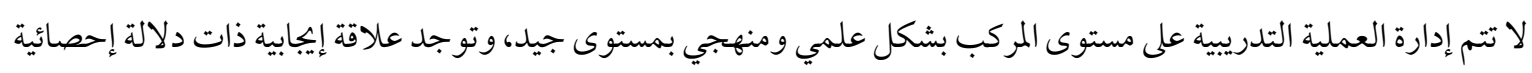

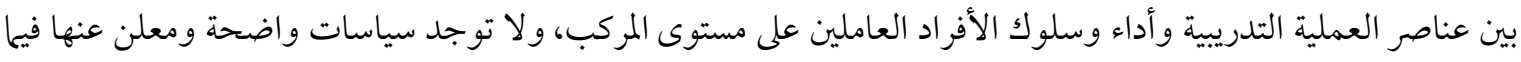

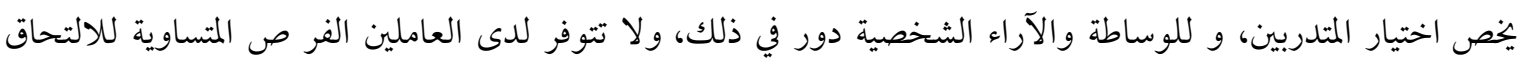

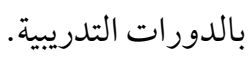


أما دراسة (الشعيبي 2020) فقد هدفت إلى التعرف على مستوى الاحتياجات التدريبية لأعضاء هيئة التدريس في جامعة أم القرى في بجال تكنولوجيا التعليم، وقد أجريت هذه الدراسة خلال العام الدراسي 2018/ 2019م، وتكونت أفراد عينة الدراسة من (350) عضوا من أعضاء هيئة التدريس بجامعة أم القرى.

أما دراسة (عبد الباسط ،2020 ) فقد هدفت إلى تحديد الاحتياجات التدريبية لدى طلاب كلية التربية الأساسية لأداء الخدمات المكتبية فى ضوء معايير الجودة الشاملة بدولة الكويت، وتم تصميم استبيان لتحديد الاحتياجات التدريبية، وتم تطبيقه على 100 طالب وطالبة بقسم علم المكتبات بكلية التربية الأساسية، وتم استخدام المنهج الوصفى التحليلى لبناء قائمة بالمهارات اللازمة لطلبة قسم المكتبات، و أظهرت نتائج الدراسة وجود درجة كبيرة من الاحتياج التدريبى لجميع المهارات المتضمنة، و مهارة الإعداد الببليوغرافى احتلت المرتبة الأولى، تليها المهارات الإدارية، ثم المهارات التكنولوجية، ثم المهار ات الشخصية اللازمة لتقديم

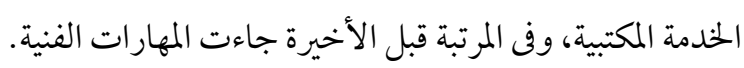
أما دراسة (هلابى 2020) فقد هدفت إلى التعرف على المقومات البشرية والمادية للبيئة الجامعية كما تراها طالبات الجامعة، وتحديد العلاقة بين البيئة الجامعية والمهارات الحياتية والكشف عن الاختلافات بين البيئة الجامعية والمهارات الحياتية وفقا لاختلاف التخصص الدراسي والمستوى الدراسي .واستخدمت الباحثة المنهج الوصفي الارتباطي، وأعدت استبانة خاصة الاصنة بالبيئة الجامعية تكونت من 19 محورًا، واستخدمت استبانة خاصة بالمهارات الحياتية وتكونت عينة الدراسة من 181 طالبة من طالبات جامعة طيبة على النحو التالي: (146 طالبة من طالبات التربية الخاصة، و (35 طالبة من طالبات التربية الفنية )، وتم معالجة البيانات إحصائيا وتم استخدام الانحراف المعياري - اختبار" ت- "التباين الأحادى تحليل - المتوسطات الحسابية، و أظهرت النتائج وجود علاقة ارتباطية ذات دلالة إحصائية بين متوسطي درجات الطالبات على استبانة البيئة الجامعية واستبانة المهارات الحياتية، وعدم وجود فروق ذات دلالة إحصائية تعزى لمتغير التخصص بين متوسط درجات الطالبات على استبانة البيئة الجامعية باستثناء محور المكتبة المركزية، ووجود فروق ذات دلالة إحصائية بين متوسط درود درودات طالبات الجامعة على استبانة البيئة.

\section{ثانيا : الدراسات الأجنبيسة:}

جاءت دراسة (Abdelgadir and Elbadri, 2001) لإلقاء نظرة شاملة حول ممارسات التدريب و أنشطته في 30 بنكا من البنوك البولندية، وتوصلت هذه الدراسة بأن العديد من البنوك عينة الدراسة تتجاهل عملية تحديد الاحتياجات التدريبية، ومن ثم تقوم بتطوير بر ابجها التدريبية بناءً على تقليد الآخرين، وهناك غياب لعملية تقييم نتائج البرامج التدريبية مما ينعكس لئسين سلبا على أداء الأفر اد العاملين فيها، مما قد يؤدي بدوره بإلى تقليل فاعلية وتنافسية هذه البنوك في ظل اقتصاديات اليوم القائمة على السوق الحر. أما دراسة ( 2002, AL - Athari and Zaira ) فأجريت على 77 منظمة في الكويت بفحص عملية تقييم التدريب و التحديات التي تواجهها، وقد توصلت هذه الدراسة إلى عدة نتائج أهمها : تقوم المنظلات بعملية التقييم أحيانًا وليس بشكل مستمر، و أكثر أدوات التقييم استخداما في عملية التقييم هي الاستبانة إضافة إلى النموذج الشائع والأكثر استخداما في عملية 
التقييم في المنظمات الكويتية هو نموذج ( كيركباترك )، و المستوى الذي يتم تقييمه في معظم المؤسسات الكويتية الحكومية وغير الحكومية هو مرحلة رد الفعل.

كما توصلت دراسة ( 2007, Renie) إلى تقديم دليل لتحسين تدريب الموظفين، والبرامج التحفيزية، والخطوة الأولى إدراك الموظفين لتحسين قدراتهم في المنظمة، وتوضح الدراسة للموظفين أن المعرفة التي اكتسبوها من الممكن أن تطبق فى عملهم

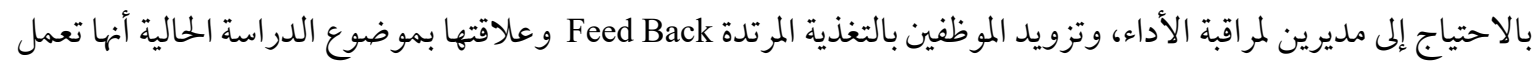
على تأكيد أهمية الموضوع قيد الدراسة في تحسين قدرات الموظفين ومراقبة أدائهم من خلال تقييم فاعلية العملية التدريبية. أما دراسة (Eze,2012) فقد تطرقت إلى برامج تدريب العاملين في المكتبات العامة في نيجيريا مع الإشارة بشكل خاص إلى مكتبة ولاية إينوغو والاحتياجات التدريبية للعاملين بالمكتبة، وبر امج التدريب، وكيفية استفادتهم من التدريب، والعو امل التي تعوق التدريب والسبل التي يمكن من خلالها تحسين تدريب الموظفين، وتم إعداد استبيان لعدد 80 فردا، وأظهرت النتائج أن

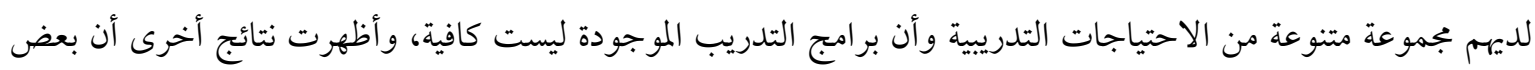
العو امل مثل: نقص التمويل، وعدد غير كاف من العاملين بالمكتبة تعيق التدريب. أما دراسة (Zhang , 2014) فكان الغرض منها؛ معرفة الاحتياجات التدريبية للعاملين في المكتبات الجامعية الست التابعة لمجلس ريجنتس (كبور)، استنادا إلى البيانات من الدراسات الميدانية والدراسات التجريبية وتم الاعتماد على الاستبيان لمعرفة وأساليب تقديم التدريب المفيدة، ومصادر التدريب والاحتياجات التدريبية. أما دراسة (2019, Erdem) فقد استخدمت سلسلة من بجموعات التركيز ومنهجية تشاركية للتحقيق في خبرات العمل واحتياجات ضباط المر اقبة الأتر اك ومديريهم، وتم توظيف جميع المشاركين في مكتب الإفراج المشروط والمر اقبة في إسطنبول بتركيا خلال بجموعات التركيز المتزامنة، وطبقت الدراسة على 57 فردا، ومن أهم نتائج الدراسة: احتياجهم خلال المرحلة الأولى لـ: التدريب لتعزيز المعرفة السريرية الأساسية ومهارات إجراء المقابلات، (ب) يحتاج إلى تحسين بيئة العمل المادية لـخدمات إعادة التأهيل، (ج) الحاجة إلى دعم مهني، (د) احتياجات أكثر وأدوات شاملة لتقييم المخاطر للتخطيط للإشر اف على المجرمين. التعقيب على الدراسات السابقة والمثيلة ومدى اختلاف الدراسة الحالية: ونستنتج من خلال العرض السابق للدراسات السابقة أنها ركزت على الاحتياجات التدريبية المهنية فى التخصصات المختلفة، كما ركزت دراسة واحدة على المهارات الحياتية كجزء من الاحتياجات التدريبية المهنية، أما الدراسة الحالية فهي تتناول تحديد الاحتياجات التدريبية غير المهنية أي: الخاصة بالمهارات الحياتية وتنمية الموارد البشرية لأخصائيي المعلومات بجامعة المنوفية، وكذلك تصميم برنامج تدريبيى لكي ينمي مهاراتهم الحياتية.

الجانب النظرى للدراسة:

أولا: تنمية الموارد البشرية :

يجتل موضوع تنمية الموارد البشرية أو ما يطلق عليه البعض بالاستثمار في الموارد البشرية، خطوط الصدارة في خطط وبر امج الدول والمنظات التي تنشد التنمية والتقدم، ولذلك فإن الأفراد هم محور التنمية، وقد ظهر مصطلح تنمية الموارد البشرية 
في بداية التسعينيات من القرن العشرين، بغرض تحسين القدرات البشرية من خلال التعليم والتدريب، ولذلك يتضمن هذا

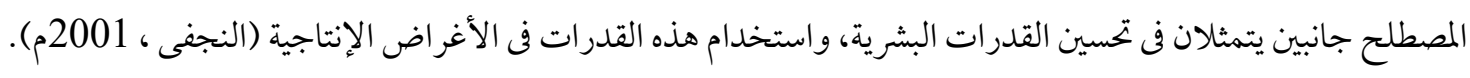

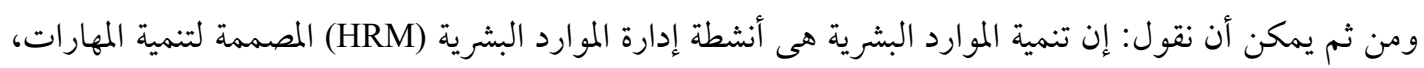

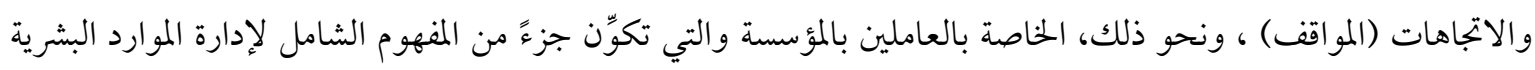

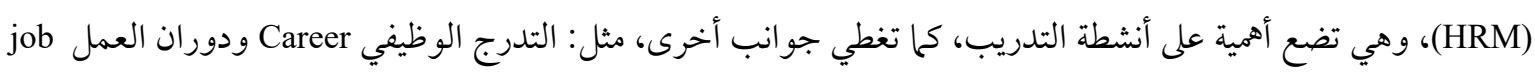
rotation

$$
\text { 1- الصعوبات التى تواجه تنمية الموارد البشرية : }
$$

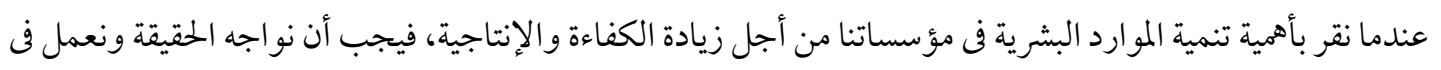

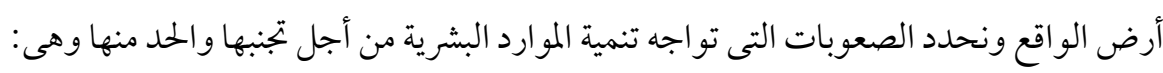

$$
\begin{aligned}
& \text { - عدم وضوح الرؤية تجاه منهجية البرامج التدريبية. }
\end{aligned}
$$

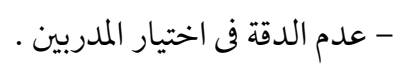

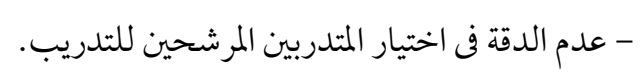

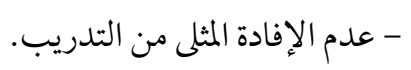

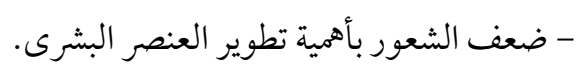

$$
\begin{aligned}
& \text { - عدم التحديد الدقيق للاحتياجات التدريبية. }
\end{aligned}
$$

وإذا كانت تنمية الموارد البشرية هي الهدف، فإن التدريب هو أهم الوسائل المستخدمة لتحقيق هذا الهدف.

ثانيا : التدريب وأهدافه وأهميته ومجالات تأثيره ونجاحه وفشله والمبادئ الأساسية للتدريب الفعًال:

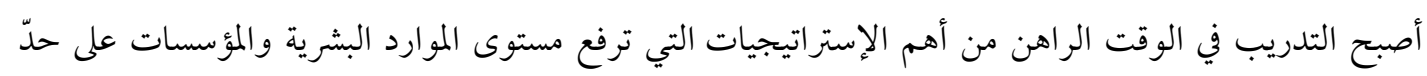

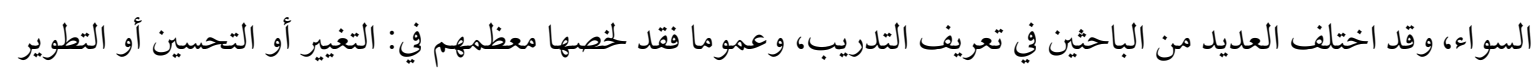

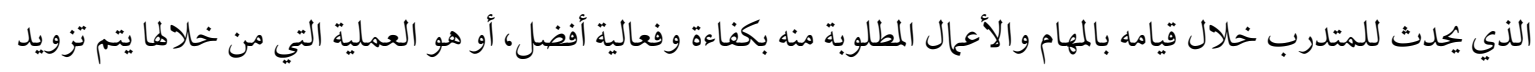
العاملين بالمعرفة و المهارة لأداء وتنفيذ عمل معين.

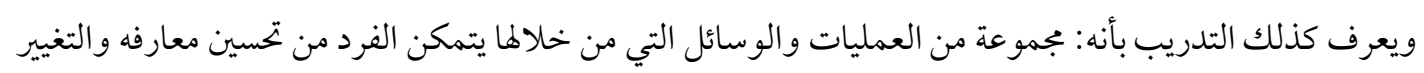

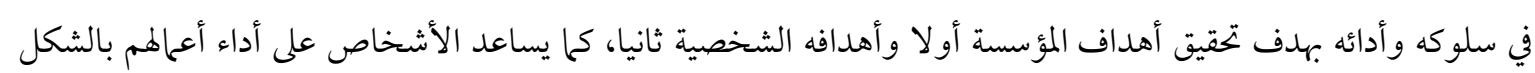

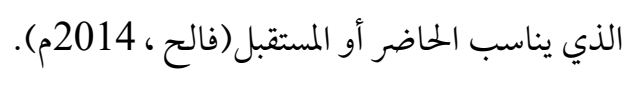

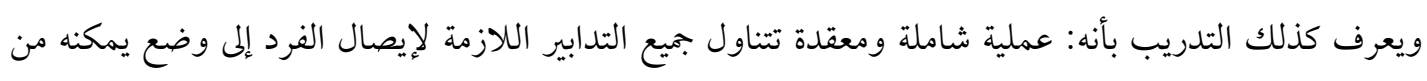

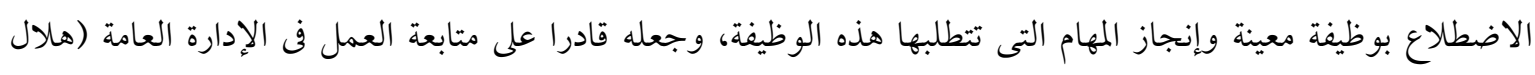


ويعرف كذلك التدريب بأنه: من أكثر الإستراتيجيات الإدارية المعترف بها فى بجال تنمية الموارد البشرية لتحسين أداء الفرد في تأدية الأعمال بكافة مستوياتها داخل المنشآت، وذلك للاعتبارات الإتبات التالية: - التدريب هو عملية منظمة؛ لأنه نشاط يقوم على أساس التخطيط والتنظيم، أي: اتباع منهجية علمية مبتعدا عن التهات انتهاج

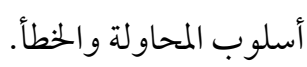
- اسستمر ارية عملية التدريب، بحيث تكون ملازمة للفرد منذ تعيينه حتى نهاية حياته العملية، و محوره الأساسى هو الفرد. - التدريب عملية هادفة: إذ إن التدريب هو وسيلة وليس غاية فى حد ذاته. - واقعية عملية التدريب: حيث تصمم البرامج التدريبية وفق احتياجات (حالية ومستقبلية) واقعية، وييب أن يكون تحديدها دقيقا. - التدريب عملية شاملة: يشمل التدريب فئات العاملين كافة، والموضوعات التى تقع ضمن دائرة اهتحام المؤسسة وأعمالها.

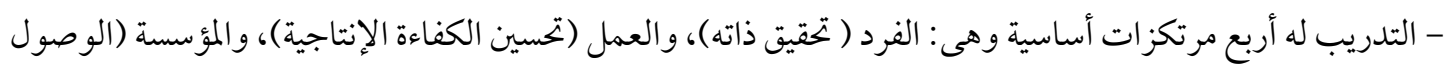

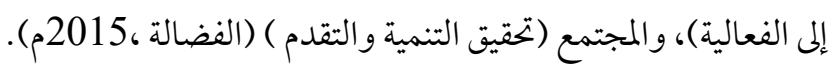

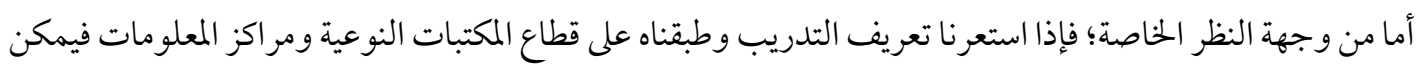

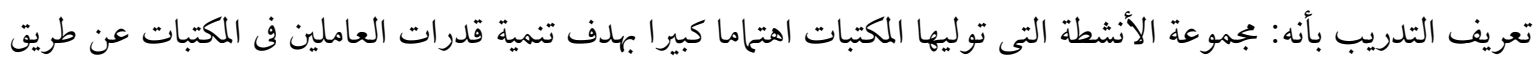

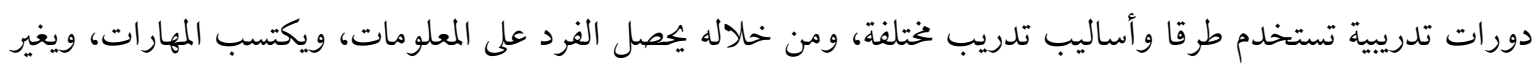
اتجاهاته لتحقيق استمر ارية مكان عمله (المكتبة) فى النمو والتفاعل مع التطور رات المستقبلية.

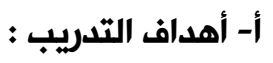

لأن التدريب حجر الزاوية في بجال تطوير كفاءة العاملين في شتى المجالات المختلفة، وفى كافة المؤسسات على اختلاف

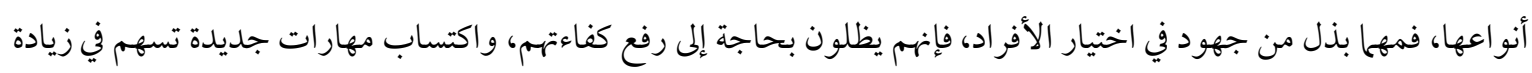

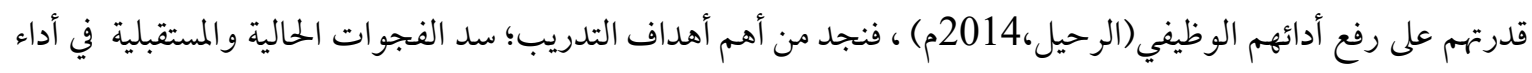

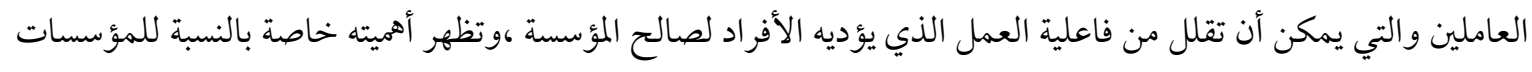

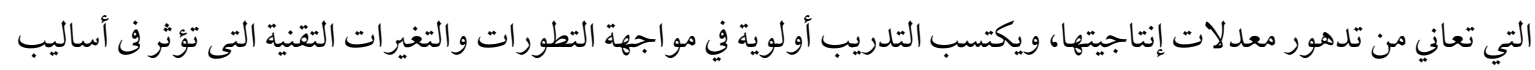

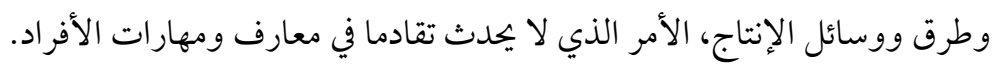

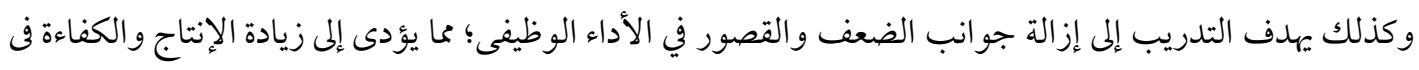

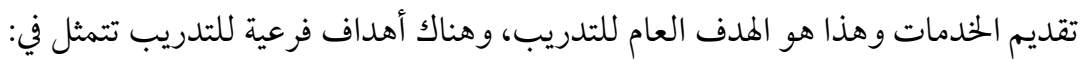

$$
\text { - إكساب المتدرب معلومات وخبرات جديدة. }
$$

- إكساب المتدرب أنماطا واتجاهات سلوكية جديدة لصاتح العمل.

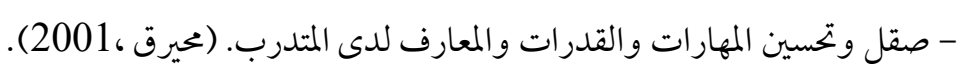
- زياد فرص الابتكار والإبداع في العمل ورفع الإنتاجية . 


$$
\text { - - يفتح المجال العلاقات الإنسانية في المؤسسة وتحسين نوع الإشراف على العمل. (شعلان ،2015م) . }
$$

- تعليم الموظفين المهارات، والمعارف الجديدة اللازمة لتأدية مهام المناصب التي رقوا إليها بالفعل، أو التي سيرقون

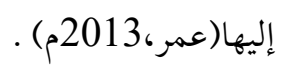

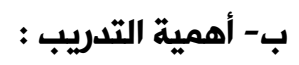

يعد التدريب ذا أهمية بالغة بالنسب للفرد والمؤسسة، فالتدريب يساعد على نقل المعارف وصقل المهارات والتوجيه

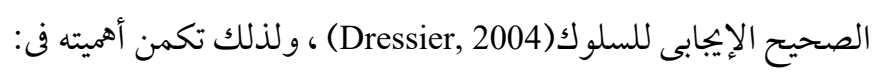
1- تنمية المعرفة والمعلومات وتنمية المهارات وتنمية السلوك والاتجاهات لدى القادة الإداريين. 2-التغير والاختلاف في دوافع الأفراد واتجاهاتهم، ومن ثم ما يقع من تطور في السلوك والحاجة إلى أفراد متعددي المهارات، مما يجعل التدريب يهدف إلى تعديل السلوك وتطويره على مدى فترة خدمة الفرد الوظيفية. 3-إنجاز وظيفي أفضل كما ونوعا أي: زيادة في الإنتاجية ومن ثم خفض في التكاليف(شعلان ،2015م).

\section{ج- مجالات تأثير التدريب:}

يعدُّ العنصر البشري من العناصر المهمة التي تحيا بها منظمات الأعمال، فهو المحرك الأساسي لجميع نشاطات المنظمة، ومصدر من المصادر المهمة لفاعليتها، وبخاصة عندما يتميز بنوعية مهارية ومعرفية وقدرات تتلاءم مع طبيعة الأعمال التي يارسها في المنظمة، وكلما أحسنت المنظمات استثمار مواردها البشرية التي تتحكم في بقية الموارد الأخرى، أصبحت أكثر قدرة على تحقيق أهدافها وبكفاءة أعلى، فلا يمكن لأية منظمة متطورة في التكنولوجيا و المعلومات ورأس المال إدارة هذه الموارد بكفاءة ما لم يكن لديها موارد بشرية تم اختيارها وتنميتها وتقييمها ومكافأتها بشكل جيد (Donald, 2011).

\section{د-نجاح وفشل التدريب:}

التدريب هو العملية التي تمكن الفرد من أداء عمله الحالي أو الجلديد، وذلك في حالة انتقال هذا الفرد من عمل إلى آخر، فحصول الفرد على الشهادة الجامعية لم يعد هدفا نهائيا، فربما لا يتلاءم المؤهل العلمي مع طبيعة وحاجات العمل الحالي هذا الفرد، مما يوجب حتمية التدريب أثناء العمل (توفيق،2009م) ، ولهذا نجد أن نجاح التدريب ليس بمجرد عقد دورة تدريبية، وإنما هو تنمية مهارات المتدربين أو زيادة معرفتهم في عملهم أو حياتهم، ومن ثم فإن عدم قدرة المتدربين على الإفادة من الدورة التدريبية يعد فشلا للدورة التدريبة، وإذا قامت المؤسسة بعقد دورات تدريبية للارتقاء بالجانب الإداري، ثم لم يستخدم المتدربون ما تعلموه من مهار ات في عملهم فإن الدورة التدريبية تكون قد فشلت، و هناك أسباب كثيرة لفشل الدورة التدريبية كلها: 1- الدورة التدريبية لا علاقة لها بالعمل: كثير من الدورات يعقد لمجرد استهلاك ميزانية التدريب دون الاهتمام باختيار

$$
\text { الدورات المناسبة ودراسة الاحتياجات التدريبية. }
$$


2- الدورة التدريبية نظرية جدا: قد يكون المدرب على دراية بالخلفية النظرية لموضوع التدريب، ولكنه ليس له خبرة عملية

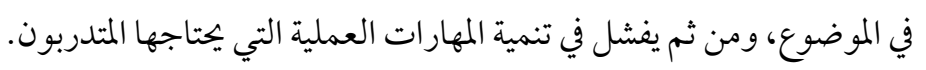

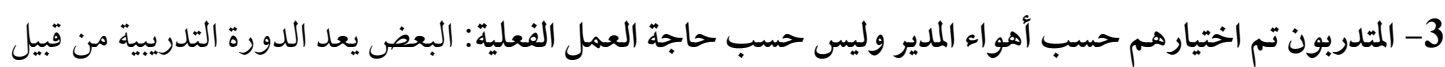

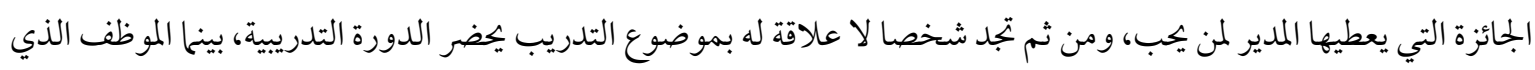

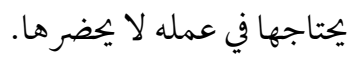

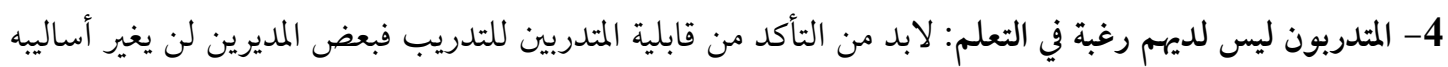
الإدارية ولو حضر مئات الدورات الإدارية؛ لأنه لا يظن أن نظريات الإدارة يمكن تطبيقها في عمله.

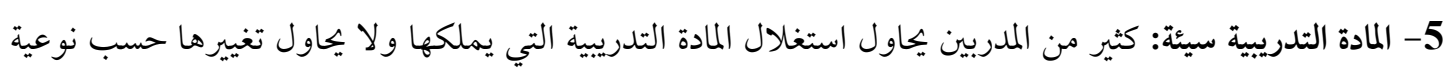

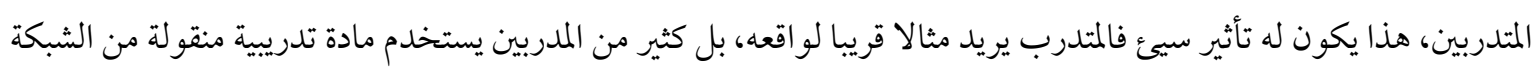

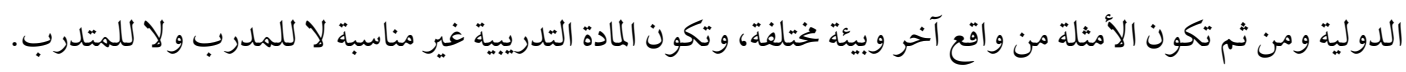

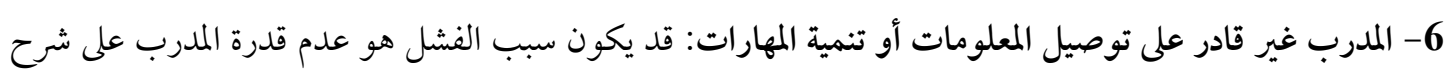
الموضوع واستخدام أساليب الثدريب. 7- المدرب ليس مهتما بتدريب المتدربين: يجب أن يكون المدرب حريصا على خروج المتدربين وقد اكتسبوا المهارات التي يمتاجونها. 8- بيئة العمل لا تساعد المتدربين على تطبيق ما تعلموه: هذه آفة حيث يكتسب المثدرب مهارات ومعارف جيدة ثم عند

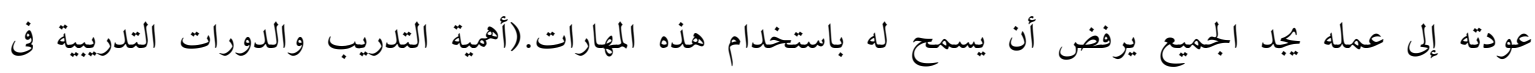

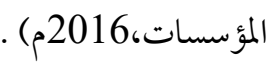

\section{هـ-المبادئ الأساسية للتدريب الفعًال:}

تمكنت الدراسات من تطوير مجموعة مبادئ أساسية للتدريب يمكن التأسيس عليها والاستعانة بها لإدارة العملية

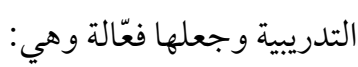

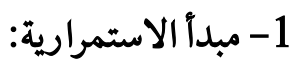

التدريب طبقًا لهذا المبدأ، لا يكو ن مجرد حل مؤقت، لمشكلة تواجه الإدارة ولا هو حل بديل، يمكن للإدارة اللجوء إليه

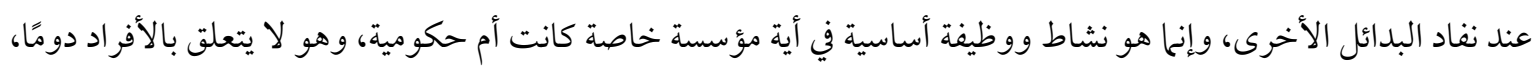

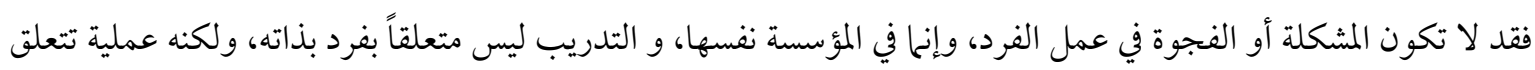
بالمؤسسة كلها وخططها المستقبلية؛ لذلك يجب أن تكون النظرة إلى التدريب: * من قبل الإدارة: هو وظيفة أساسية ومستمرة طول حياة المنظمة.

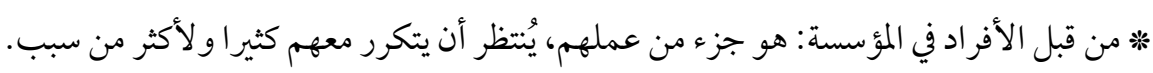

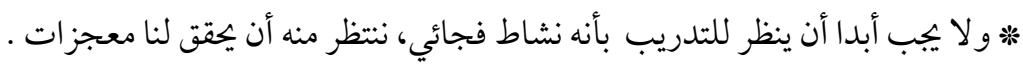




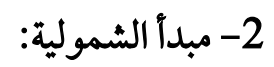

ثقافلا يقتصر الثدريب على العاملين الجدد؛ بل يشمل أيضًا الموظفين الحاليين أو القدامى، وذلك نظرًا للتغيرات المستمرة في بيئة الأعمال ومتطلباتها. * كما يشمل الثدريب جميع العاملين بمختلف الاختصاصات فنية كانت أم إدارية، ويشمل المستويات الوظيفية كافة العليا والوسطى والتنفيذية.

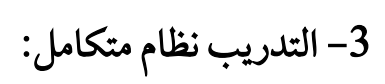
ويقصد به: التدريب شأنه شأن أي نظام، له مدخلات وخرجات وبجموعة من النشاطات التدريبة التي يتكون كل منها من بجموعة من العناصر المتكاملة والمترابطة.

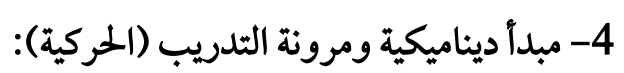

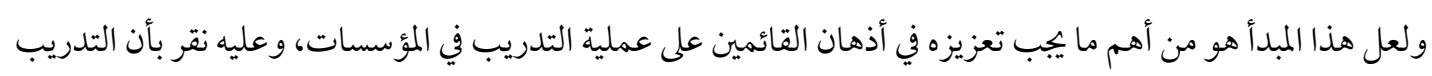

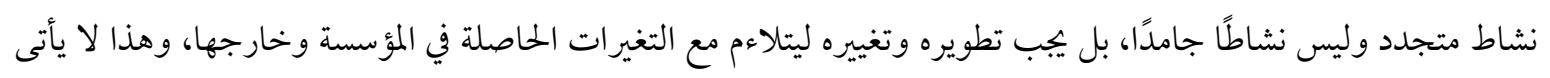

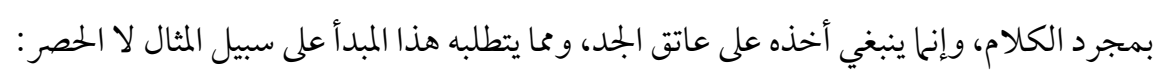
* تطوير مستمر لموضو عات البرامج التدريبية وأساليب التدريب وطرق تقويم النتائج.

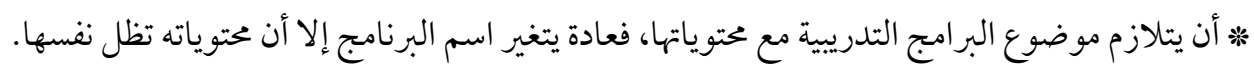

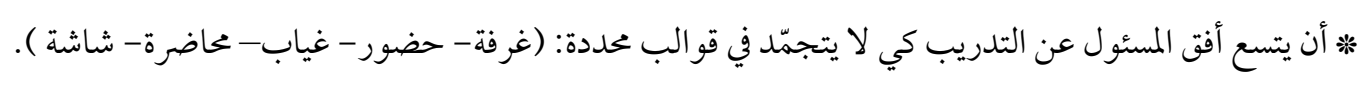

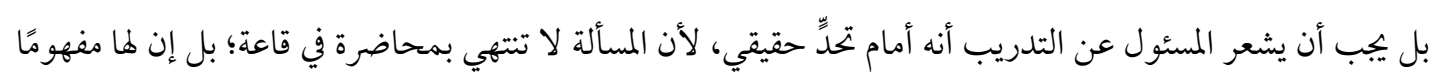

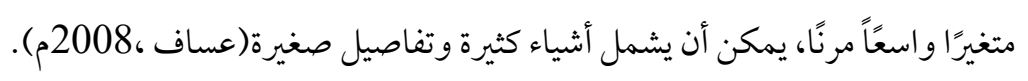

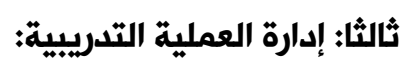

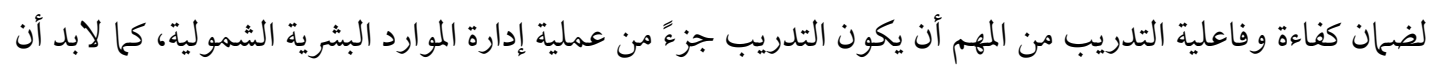

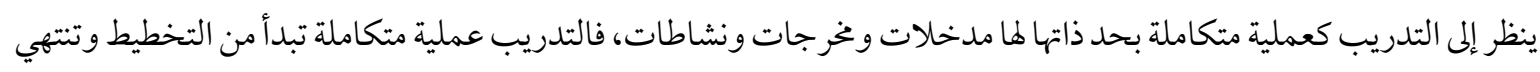

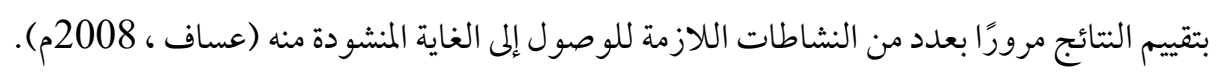

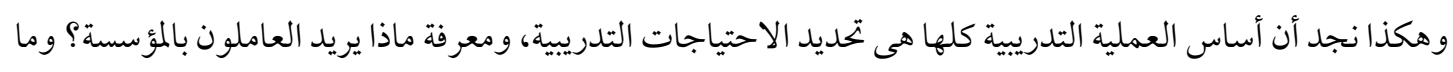
نقاط ضعفهم؟ لكى يقوم التدريب بتحسين هذه النقاط، والعمل على زيادة الكفاءة والإنتاجية.

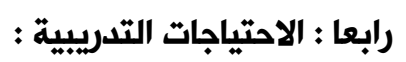

الاحتياجات التدريبية هى الضعف أو النقص الكيفى والكمى فى المعلومات العامة والخاصة والمهارات الفردية والجماعية

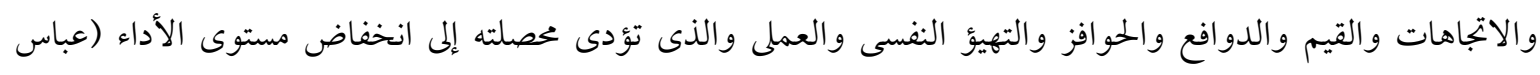

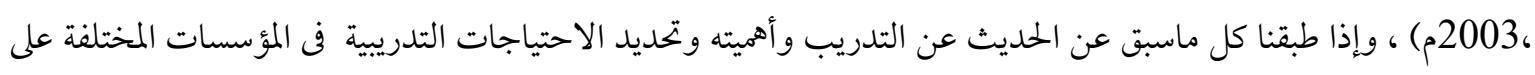




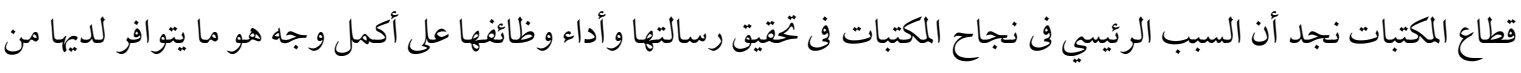
موارد بشرية مؤهلة ومدربة للنهوض بأعباء الخدمة المكتبية والمعلوماتية على الوجه الأكمل، ويها إن عصرنا الحاضر يتسم الماتِ

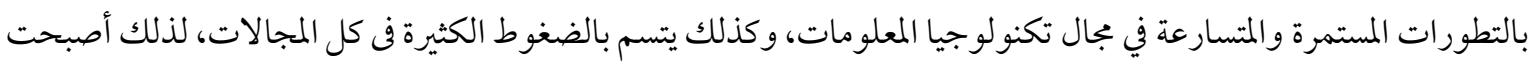

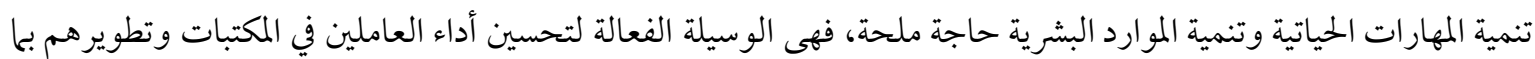
يتناسب مع كل متطلبات العمل والحياة.

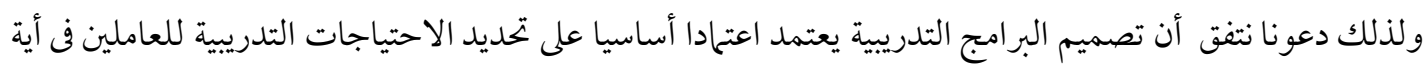

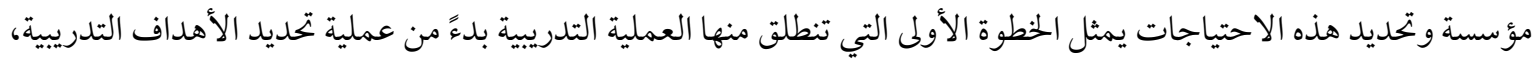

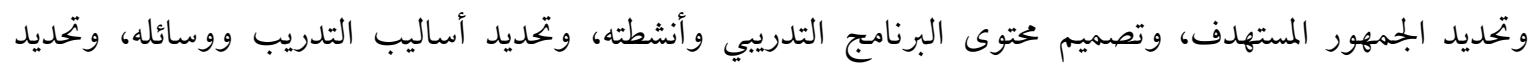

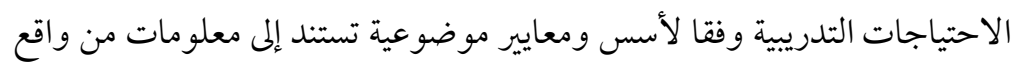
مشكلات العمل ومتطلبات التغيير وأهداف المؤسسة الحاضنة للتدريب وإمكاناتها المادية(الأكلبى،2012م). وكذلك نتفق بأن تحديد الاحتياجات التدريبية يجب أن يتم دوريا لكي نستطيع تحديد الدورات التهات التدريبية المناسبة، ولذلك فإن تحليل الاحتياجات التدريبية يتكون من ثلاثة أجزاء وهى :

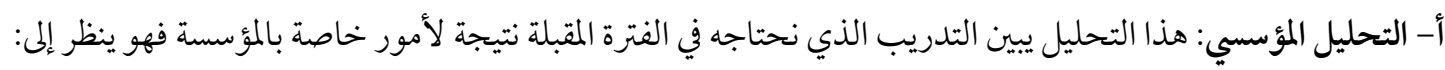

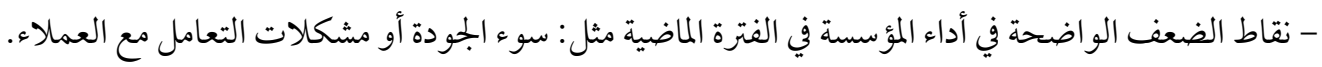
- أهداف المؤسسة على المدى القريب والبعيد. - التغيرات الخارجية مثل: تغيرات في القوانين أو الاقتصاد أو التكنولوجيا.

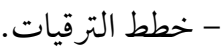
- الدورات الثدريبية الإلزامية بسبب لو ائح داخلية او قوانين محلية أو اشتراطات دولية. - الدورات التدريبية اللازمة لخلق جو مناسب للتدريب.

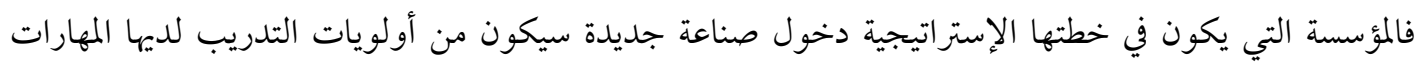
والمعارف المرتبطة بهذه الصناعة الجديدة، والمؤسسة التي تخطط لتطبيق نظام إداري جديد سيكون من أولويات التدريب لديها تدريب العاملين على هذا النظام الجديد و تأهيلهم للتغيير. ب-تحليل العمل :هذا التحليل يحدد المهارات والمعارف والقدرات المطلوبة لكل وظيفة أو مجموعة من الوظائف، ومصادر

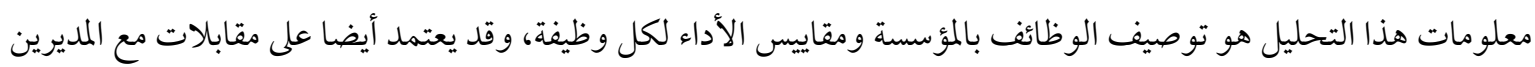
والموظفين وكذلك تحليل المشكلات السابقة في كل وظيفة.

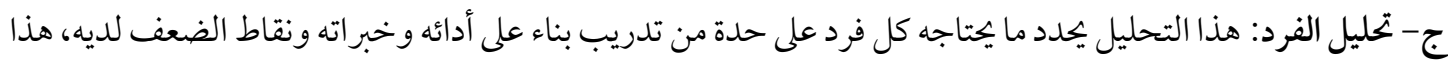

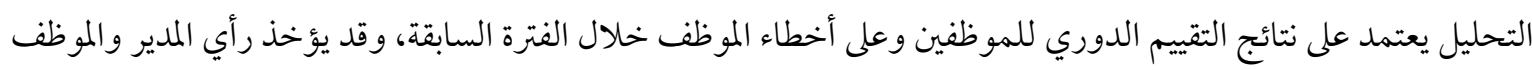

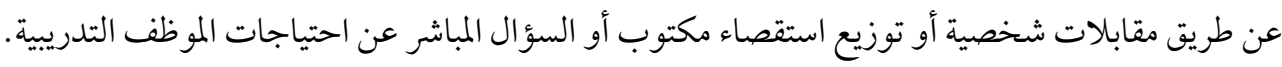


وبناء على هذه التحاليل الثلاثة فإننا سنتهي بعدد كبير من الدورات التدريبية، (أهمية التدريب والدورات التدريبية فى

$$
\text { المؤسسات ، 2016م). }
$$

كما يمكن تحديد بجموعة الوسائل أو الأدوات التي يجري الاعتماد عليها لتحديد الاحتياجات التدريبية وهى : 1 - بطاقات توصيف الوظائف.

$$
\text { 2- 2 - معايير الأداء المطلوبة لكل عمل. }
$$

3- طلبات الأفراد أنفسهم عن طريق استبيانات توزع عليهم لتحديد احتياجاتهم التدريبية.

$$
\text { 4- تقارير تقويم أداء العاملين. }
$$

$$
\text { 5- آراء الرؤساء المباشرين حول احتياجات موظفيهم. }
$$

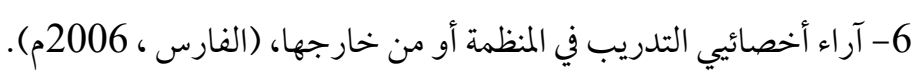

خامسا : المهارات الحياتية :

هي السلوكيات والمهارات الشخصية والاجتحاعية اللازمة للأفر اد للتعامل بثقة واقتدار مع أنفسهم ومع الآخرين ومع المجتمع، وذلك باتخاذ القرارات المناسبة والصحيحة وتحمُّل المسئوليات الشخصية والاجتماعية، وفهم النفس والغير وتكوين علاقات إيجابية مع الآخرين وتفادي حدوث الأزمات والقدرة على التفكير الابتكاري.

\section{آهمية اكتساب المهارات الحياتية :}

إنَّ الإنسان كائن اجتماعي بالطبع، لا يقوى على العيش بمعزل عن الآخرين، فإنه يحتاج إلى بجموعة من المهارات الحياتية التي تمكّنه من التو اصل مع الآخرين، و التفاعل معهم ، وتُعينه على تحقيق أهدافه بنجاح، وتكفل له حياة اجتماعية سعيدة، وبقدر

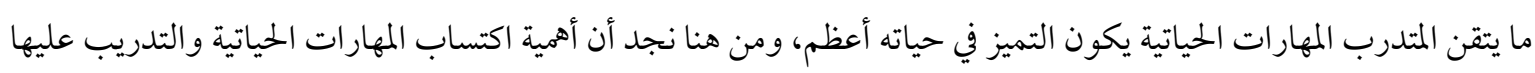
تكمن فى :

- مساعدة الفرد على حل مشكلاته الشخصية والاجتماعية والتعامل معها بوعي.

- إكساب الفرد الثقة بالنفس.

- إشعار الفرد بالر احة والسعادة حين ينفذ أعماله بإتقان.

- إكساب الفرد حب الآخرين، و احترامهم له، وتقديرهم لعمله.

- تمكِين الفرد من القيام بأعاله بنجاح.

- مساعدة الفرد على تطبيق ما يتعلمه عمليًّ (مهارات الحياة ، 2016م).

المهارات الحياتية وماتضمنه:

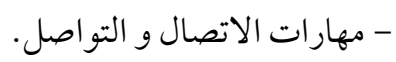

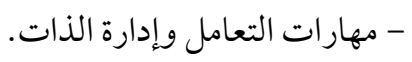




$$
\begin{aligned}
& \text { - مهارات التفاوض/ الرفض. } \\
& \text { - الذكاء العاطفي / الوجداني }
\end{aligned}
$$

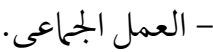

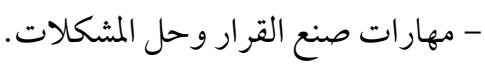

$$
\begin{aligned}
& \text { - مهارات التفكير الإبداعي والتفكير الناقد. } \\
& \text { - مهارات إدارة التعامل مع الضغوط، (تنمية المهارات الحياتية ، 2017م). }
\end{aligned}
$$

الدراسة التطبيقية (الميدانية):

بعد الحديث عن التدريب وأهدافه وأهميته وبجالات تأثيره ونجاحه وفشله والمبادئ الأساسية للتدريب الفعّال، وإدارة العملية التدريبية، والاحتياجات التدريبية، وتنمية الموارد البشرية، والمهارات الحياتية والجدارات الثندريبية، وإيرانا من المؤسسات

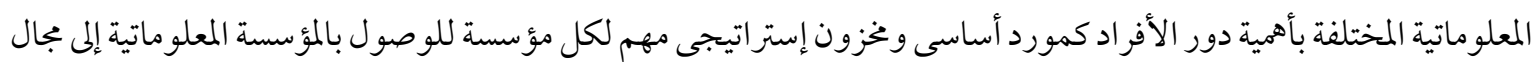

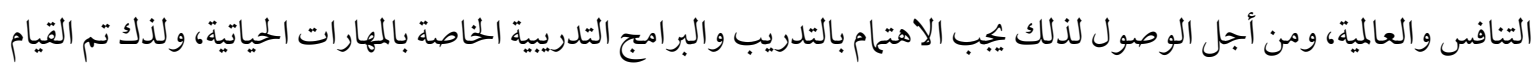

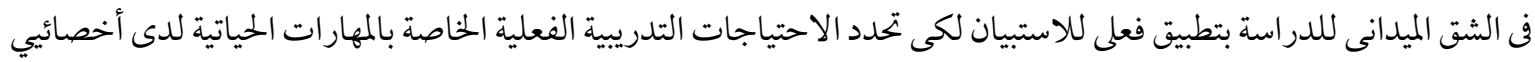

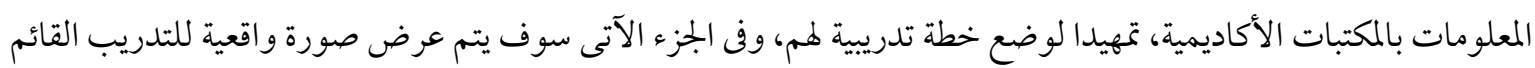

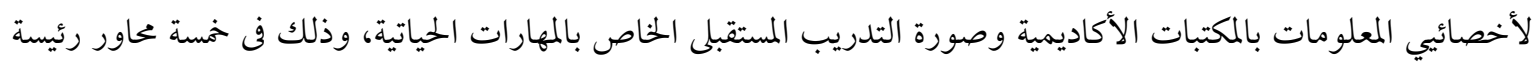

\section{أولا: المتغيرات الديموجرافية:}

من أسس تحديد الاحتياجات التدريبية الخاصة بالمهارات الحياتية لدى أخصائيي المعلومات فى المكتبات الأكاديمية

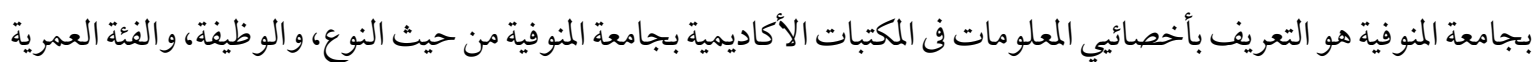

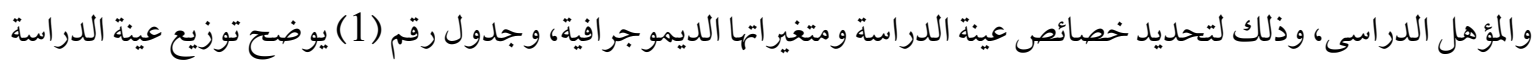

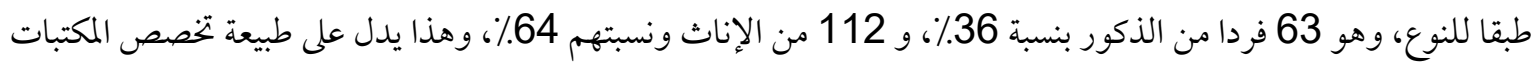

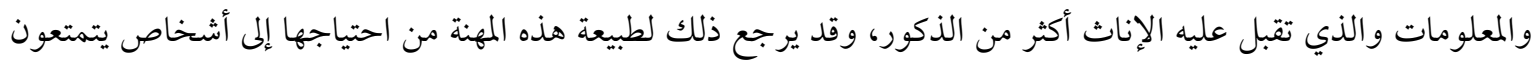

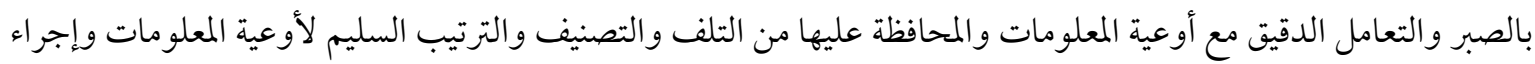

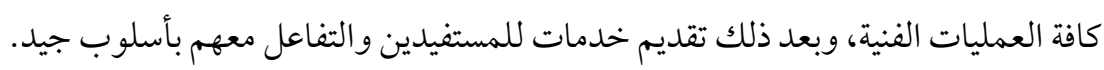

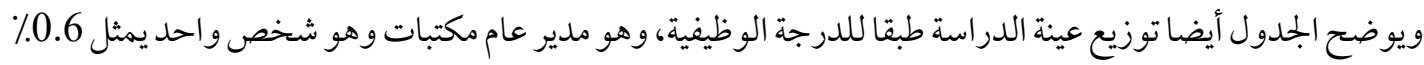

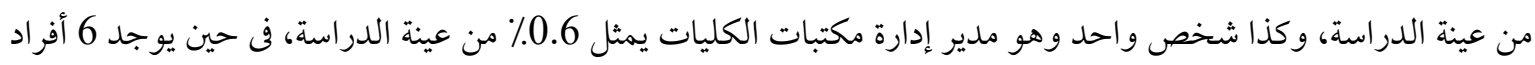

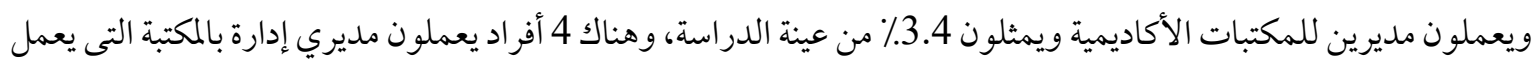

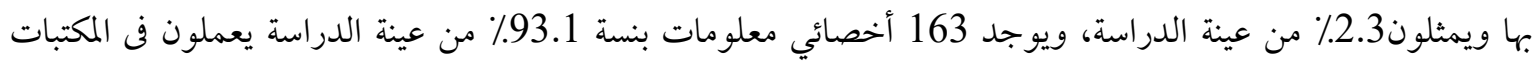

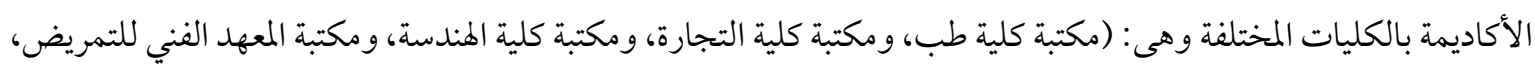


ومكتبة الهندسة الإلكترونية، ومكتبة كلية الحقوق، ومكتبة كلية العلوم، ومكتبة كلية التمريض، ومكتبة كلية الحاسبات و المعلومات، ومكتبة كلية الزراعة، ومكتبة كلية التربية، ومكتبة كلية التربية النوعية، ومكتبة كلية الاقتصاد المتزلي، ومكتبة كلية

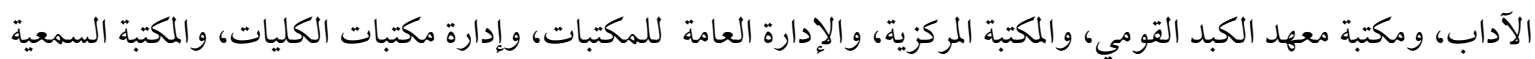

والبصرية).

الجدول رقم (1) توزيع عينة الدراسة طبقا للمتغيرات الديموجرافية

\begin{tabular}{|c|c|c|c|}
\hline النسبة المئوية & التكرارات & فئات المتغير & المتغير \\
\hline$\% 64$ & 112 & أنثى & \multirow{3}{*}{ النوع } \\
\hline$\% 36$ & 63 & ذكر & \\
\hline$\% 100$ & 175 & المجموع & \\
\hline$\% 0.6$ & 1 & مدير عام المكتبات & \multirow{6}{*}{ 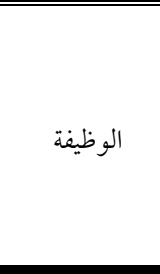 } \\
\hline$\% 0.6$ & 1 & مدير إدارة مكتبات الكليات & \\
\hline$\% 3.4$ & 6 & مدير مكتبة & \\
\hline$\% 2.3$ & 4 & مدير إدارة بالمكتبة & \\
\hline$\% 93.1$ & 163 & أخصائى معلومات & \\
\hline$\% 100$ & 175 & المجموع & \\
\hline$\% 110.3$ & 18 & $29-20$ & \multirow{7}{*}{ الفئة العمرية } \\
\hline$\% 44$ & 77 & $39-30$ & \\
\hline$\% 25.7$ & 45 & $49-40$ & \\
\hline$\% 20$ & 35 & $59-50$ & \\
\hline- & - & 69-60 & \\
\hline- & - & 70 فأكثر & \\
\hline$\% 100$ & 175 & المجموع & \\
\hline$\%$ \%94.9 & 166 & ليسانس أو بكالوريوس & \multirow{5}{*}{ المؤهل الدراسى } \\
\hline$\% 1.7$ & 3 & دبلومة & \\
\hline$\% 2.3$ & 4 & ماجستير & \\
\hline$\% 1.1$ & 2 & دكتوراة & \\
\hline$\% 100$ & 175 & المجموع & \\
\hline
\end{tabular}

وكذلك يوضح الجدول توزيع عينة الدراسة طبقا للفئة العمرية، حيث جاء فى المرتبة الأولى الفئة العمرية من30-39عاما بو اقع 44٪ وبلغ عددهم 77 فردا ، بينما جاء فى المرتبة الثانية الفئة العمرية من 40- 49 عاما بو اقع 25.7 25٪ وبلغ عددهم 45 فردا،

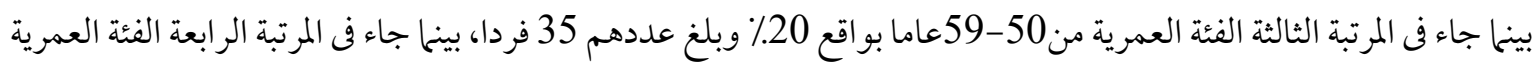
من20-29عاما بو اقع 10.3\% وبلغ عددهم 18 فردا. أما توزيع عينة الدراسة طبقا للمؤهل الدراسى، فقد جاء في المرتبة الأولى الحاصلون على ليسانس أو بكالوريوس بواقع 94.9٪ وبلغ عددهم 166 فردا منهم الحاصل على ليسانس مكتبات ومعلومات وكذلك ليسانس لغة إنجليزية، وليسانس علم اجتماع، وليسانس لغة عربية، وليسانس لغة ألمانية، وليسانس فلسفة، وليسانس لغة فرنسية، وليسانس جغرافيا، وليسانس علم نفس، وليسانس حقوق، وبكالوريوس اقتصاد منزلى، وبكالوريوس علوم بينما جاء فى المرتبة الثانية الحاصلون على ماجستير فى المكتبات و المعلومات بو اقع 2.3٪ وبلغ عددهم 4 أفر اد، بينما جاء فى المرتبة الثالثة الحاصلون على دبلومة فى المكتبات و المعلومات وبنات بو اقع 1.7٪ وبلغ عددهم 3 أفراد، بينما جاء فى المرتبة الرابعة الحاصلون على دكتوراه بو اقع 1.1\% وبلغ عددهم فردين . 


\section{ثانيا/ معلومات عامة عن البرامج التدريبية التى تم الحصول عليها من قبل:}

نظرا لطبيعة هذه الدراسة ، وطبيعة موضوع البحث وهو دراسة الاحتياجات التدريبية الخاصة بالمهارات الحياتية لدى

أخصائيي المعلومات فى المكتبات الأكاديمية بجامعة المنوفية، فإن معرفة الدورات التدريبية التى حصلوا عليها، وموضوعات دواتها، و الدورات التدريبية الخاصة بتنمية الموارد البشرية والمهارات الحياتية، وفى حالة إذا تم الخصول عليها، هل تحققت الإفادة منها أم لا ؟ كل ذلك يفيد بصورة كبيرة جدا ويثرى موضوع الدراسة.

1/2- حصول عينة الدراسة على برامج تدريبية أثناء العمل:

للتعرف على البرامج التدريبية التي حصل عليها أفراد الدراسة أثناء العمل، جاءت الردود كما في الجدول رقم (2)

الجدول رقم (2) حصول عينة الدراسة على برامج تدريبية أثناء العمل

\begin{tabular}{|c|c|c|}
\hline النسبة المئوية & 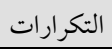 & حصول عينة الدراسة على برامج تدريبية أثناء العمل \\
\hline$\% 100$ & 175 & نعم \\
\hline- & - & ע \\
\hline$\% 100$ & 175 & 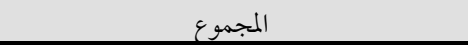 \\
\hline
\end{tabular}

يشير الجدول رقم (2) بأن عينة الدراسة كلها 175 أخصائي معلومات فى المكتبات الأكاديمية بجامعة المنوفية قد حصلوا على دورات تدريبية أثناء العمل، وهذا يدل على إيحان قطاع المكتبات الجامعية بأهمية التدريب في تطوير وتنمية العاملين بها من أجل الجل الكفاءة والفاعلية في العمل حيث تبنت الإدارة في كثير من المؤسسات والمنظمات العالمية اليوم مبدأ الاهتحام بالبشر كأحد المؤثرات القوية التي تكسبها ميزة تنافسية، وبخاصة مع دخول القرن الحادي والعشرين الذي يركز على( ( اقتصاد المعرفة))، معتبرًا أنَّا الأفراد ذوي المعرفة والمهارات هم القوة الدافعة لبقاء واستمرار المؤسسات .

\section{2/2 موضوعات البرامج التدريبية التى حصلت عليها عينة الدراسة :}

للتعرف على موضوعات البرامج التدريبية التى حصلت عليها عينة الدراسة، تم سؤالهم عن ذلك، وجاءت الردود على

$$
\text { نحو ما هو مبين بالجدول رقم (3) و الشكل رقم (1) }
$$

\section{الجدول رقم (3) موضوعات البرامج التدريبية التى حصلت عليها عينة الدراسة}

\begin{tabular}{|c|c|c|}
\hline النسبة المئوية & 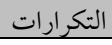 & موضوعات البرامجج التدريبية التى حصلت عليها عينة الدراسة \\
\hline$\% 100$ & 175 & بر امجج تدريبية خاصة بتخصص مكتبات ومعلومات \\
\hline$\% 11.4$ & 20 & برامج تدريبية خاصة بتنمية الموارد البشرية والمهارات الحياتية \\
\hline$\% 10.3$ & 18 & بر برامج أخرى \\
\hline
\end{tabular}




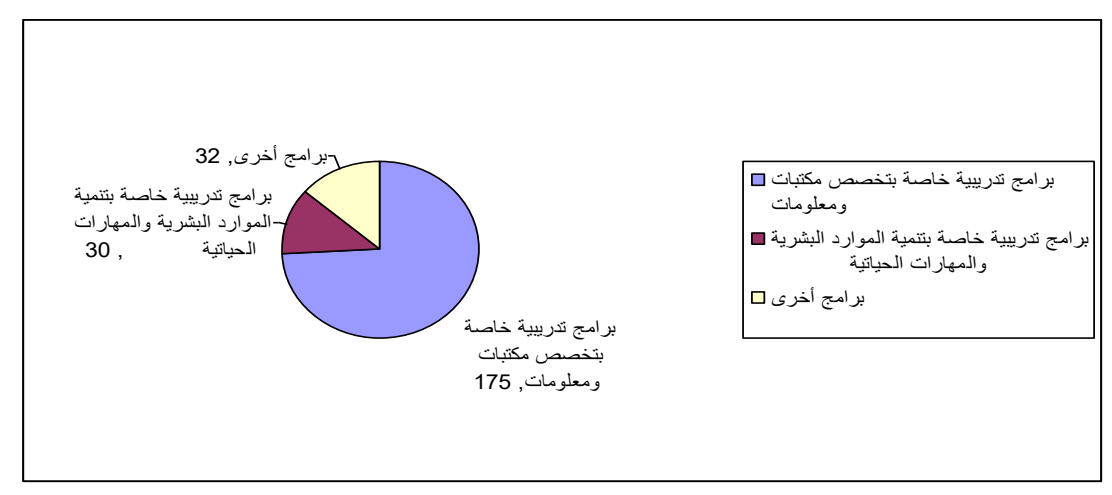

الشكل رقم (1) موضوعات البرامج التدريبية التى حصلت عليها عينة الدراسة

يشير الجدول رقم (3) والشكل رقم (1) إلى البرامج التدريبية الخاصة بتخصص مكتبات ومعلومات هى أساس موضوعات البرامج التدريبية التى حصلت عليها عينة الدراسة، حيث أشار 175 أخصائي معلومات فى المكتبات الأكاديمية بجامعة المنوفية بنسبة 100٪ إلى ذلك، فى حين أشار 20 أخصائي معلومات بنسبة 11.4\% إلى البرامج التدريبية الخاصة بتنمية الموارد البشرية والمهارات الحياتية من ضمن موضوعات البرامج التدريبية التى حصلوا عليها أثناء عملهم، فى حين أشار 18 أخصائي معلومات بنسبة 10.3٪ أنهم حصلوا على برامج تدريبية أخرى، وهى: دورات عن استخدام بنك المعرفة المصرى، وعن فئن

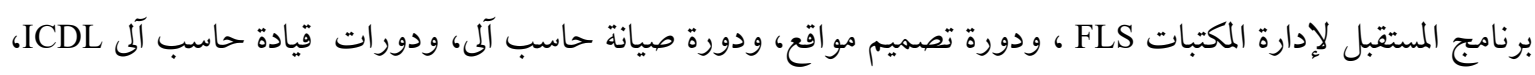
ودورات فى تعلم اللغة الإنجليزية. ونستنج من ذلك أن الاهتحام الأعظم للمسئولين عن المكتبات الأكاديمية بجامعة المنوفية في تنمية وإعداد الكوادر البشرية هو التنمية المهنية، وليس هناك أي إدر اك لأهمية دورات تنمية الموارد البشرية والمهارات الحياتية فى كونها تُساعد الأشخاص على اتخاذ قراراتٍ مدروسة بعناية، والتو اصل بفعالية مع الآخرين، وتنمية مهارات التأقلم مع الظروف المحيطةِ، وإدارة الذات التي تؤدي إلى التقدّم والنجاح والتعامل مع الآخرين بإيجابية، وتفادي الوقوع في الأزمات، والتغلّب عليها عند حدوثها، وإدارة

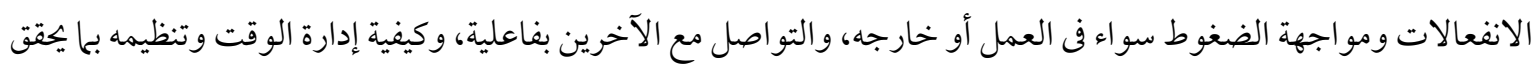
أعلى درجات الكفاءة والإنتاجية .

\section{3/2- مجالات دورات تنمية الموارد البشرية والمهارات الحياتية التى حصل عليها أفراد الدراسة من قبل:}

للتعرف على الدورات الخاصة بتنمية الموارد البشرية والمهارات الحياتية التى حصلت عليها عينة الدراسة من قبل تم سؤالهم عن ذلك، وجاءت النتائج كما يلى: إن 20 أخصائي معلومات قد حصلوا على دورات فى مهارات الاتصال الفعال، وتنمية المهارات القيادية والإشرافية للعاملين، وإدارة الأزمات، وتنمية مهارات العاملين فى مجال التفكير الابتكارى، وإدارة الضغوط دهات

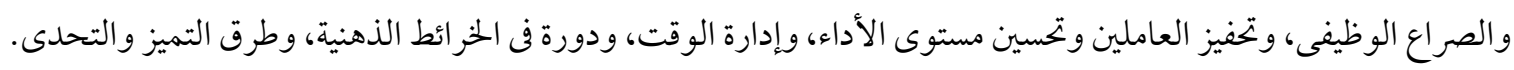


4/2- مدى تحقق الإفادة من دورات تنمية الموارد البشرية والمهارات الحياتية التى حصلت عليها عينة الدراسة من

قبل فى عملهم:

للتعرف على تحقق الإفادة من عدمها من دورات تنمية الموارد البشرية والمهارات الحياتية التى حصلت عليها عينة الدراسة

من قبل فى عملهم تم سؤ الهم عن ذلك، وجاءت الردود على نحو ما هو مبين بالجدول رقم (4) .

الجدول رقم (4) مدى تحقق الإفادة من دورات تنمية الموارد البشرية والمهارات الحياتية

التى حصلت عليها عينة الدراسة من قبل فى عملهم

\begin{tabular}{|c|c|c|}
\hline النسبة المئوية & التكرارات & مدى تحقق الإفادة من دورات تنمية الموارد البشرية والمهارات الحياتية التى حصل عليها عينة الدراسة من قبل \\
\hline$\% 90$ & 18 & نعم \\
\hline$\% 10$ & 2 & V \\
\hline$\% 100$ & 20 & المجموع \\
\hline
\end{tabular}

يشير الجمدول رقم (4) إلى 18 فردا من 20 أخصائي معلومات الذين حصلوا على دورات خاصة بتنمية الموارد البشرية

و المهارات الحياتية حققوا بنسبة 90٪ الإفادة من دورات تنمية الموارد البشرية والمهارات الحياتية التى حصلوا عليها من قبل فى

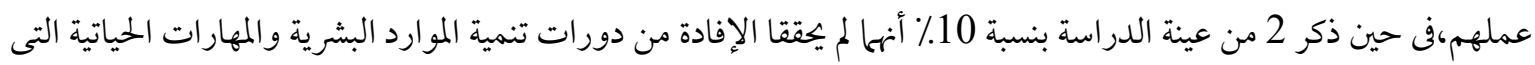
حصلا عليها من قبل فى عملهم.

وقد جاء سؤ ال مو جه لعدد 18 أخصائي معلومات من حققو الإفادة من دورات تنمية الموارد البشرية والمهارات الحياتية التى حصلوا عليها من قبل فى عملهم، عن ذكر ثلاثة نقاط من أوجه الإفادة من هذه الدورات فجاءت الإجابات كما يلى: (طرق التعامل مع الآخرين، والعمل تحت الضغوط المختلفة والتغلب عليها، ومعرفة لغة الجسد، وطرق ومهار ات الاتصال مع الآخرين،

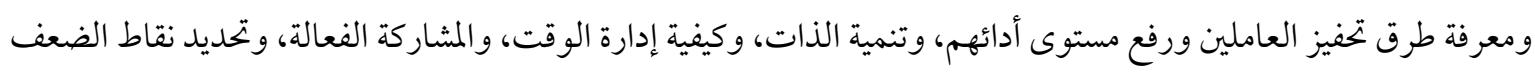
و القصور و الإفادة من نقاط القوة.

\section{ثالثا / أهداف البرامج التدريبية التى تم الحصول عليها ومزاياها:}

نظرا لطبيعة هذه الدراسة، وطبيعة موضوع البحث وهو دراسة الاحتياجات التدريبية الخاصة بالمهارات الحياتية لدى أخصائيي المعلومات فى المكتبات الأكاديمية بجامعة المنوفية، فإن معرفة الأهداف المعلنة للبرامج التدريبية التى تعدها المكتبات الأكاديمية بجامعة المنوفية لأخصائيي المعلومات بها، وهل ترتبط هذه الأهداف بالاحتياجات المتغيرة للعمل فى المكتبات الأكاديمية ؟ وما المزايا التى يتم الحصول عليها بعد حصول عينة الدراسة على البرامج التدريبية فى المكتبات الأكاديمية؟ سيفيد بصورة كبيرة

$$
\text { جدا ويثرى موضوع الدراسة. }
$$

1/3- الأهداف المعلنة للبرامج التدريبية التى تضعها جهة العمل لعينة الدراسة بها:

للتعرف على الأهداف المعلنة للبرامج التدريبية التى تضعها جهة العمل لعينة الدراسة بها، تم سؤال عينة الدراسة عن

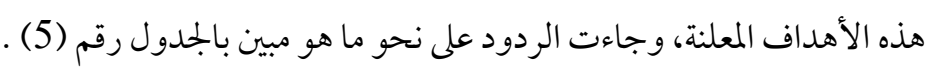


الجدول رقم (5)الأهداف المعلنة للبرامج التدريبية التى تضعها جهة العمل لعينة الدراسة بها

\begin{tabular}{|c|c|c|}
\hline 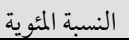 & 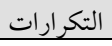 & الأهداف المعلنة للبرامج التدريبية التى تضعها جهة العمل لعينة الدراسة بها \\
\hline$\% 89.8$ & 123 & - تطوير المعارف والمهارات وتغيير الاتجاهات للعاملين بها \\
\hline$\% 73$ & 100 & - التطوير المستمر للعاملين بها \\
\hline$\% 33.6$ & 46 & - مواكبة المستجدات في محيط العمل \\
\hline- & 89.7 & المتوسط حسابى \\
\hline- & 32.3 & الانحر اف معياري \\
\hline
\end{tabular}

يشير الجمول رقم (5) بمتوسط حسابى 89.7 ، و انحراف معيارى 32.3 لـ 123 أخصائي معلومات بالمكتبات الأكاديمية بنسبة 89.8٪ أقروا بأن تطوير المعارف والمهارات وتغيير الاتجاهات للعاملين بها من الأهداف الأولى المعلنة للبرامج التدريبية التى تضعها جهة العمل لهم، وجاء فى المرتبة الثانية هدف التطوير المستمر للعاملين بها والتى أقرها 100 أخصائي معلومات بنسبة 73٪ ، فى حين جاء هدف مواكبة المستجدات فى محيط العمل فى المرتبة الثالثة بنسبة 33.6٪، و وأقر ذلك 46 أخصائي معلومات بالمكتبات الأكاديمية. وهذا يتفق مع تعريف التدريب بأنه: زيادة المعرفة والقدرات والمهارات للقوى العاملة القادرة على العمل في جميع

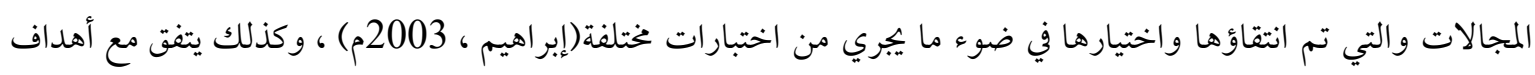
التدريب وهى إكساب المتدرب أنماطا واتجاهات سلوكية جديدة لصالح العمل، وصقل وتحسين المهارات والقدرات والمعارف لدى المتدرب(محيرق، 2001م) أي: تنمية الأفراد في كل شيء - المهارات - تنمية الإدارة - الاتصالات- العلاقات الإنسانية -

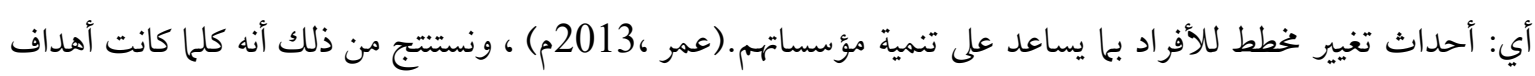
البرامج التدريبة معلنة فى أماكن العمل دل ذلك على وجود خطة تدريبية سليمة قائمة على احتياجات تدريبية فعلية وفقا لأساليب

منهجية صحيحة.

2/3- مدى ارتباط الأهداف المعلنة للتدريب فى جهة عمل عينة الدراسة بالاحتياجات المتغيرة للعمل:

للتعرف على مدى ارتباط الأهداف المعلنة للتدريب فى جهة عمل عينة الدراسة بالاحتياجات المتغيرة للعمل ،تم سؤال

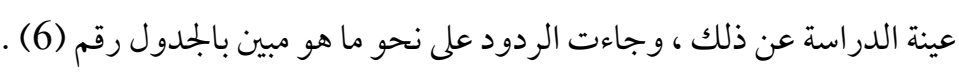

الجدول رقم (6) مدى ارتباط الأهداف المعلنة للتدريب فى جمة عمل عينة الدراسة بالاحتياجات المتفيرة للعمل

\begin{tabular}{|c|c|c|}
\hline النسبة المئوية & التكرارات & مدى ارتباط الأهداف المعلنة للتدريب في جهة عمل عينة الدراسة بالاحتياجات المتغبرة للعمل \\
\hline$\% 81.7$ & 143 & y \\
\hline$\% 18.3$ & 32 & نعم \\
\hline$\% 100$ & 175 & المجموع المو \\
\hline
\end{tabular}

يوضح الجدول رقم (6) مدى ارتباط الأهداف المعلنة للتدريب فى جهة عمل عينة الدراسة بالاحتياجات المتغيرة للعمل

، فنجد أن 143 أخصائي معلو مات ونسبتهم 81.7 ٪ يقرون بأنه لا يوجد ارتباط بين الأهداف والاحتياجات المتغيرة للعمل، بينما 32 أخصائي معلومات ونسبتهم 18.3٪ يقرون بوجود ارتباط بين الأهداف والاحتياجات المتغيرة للعمل. 
ونستنتج من ذلك أن هناك فجوة كبيرة بين الاحتياجات المتغيرة للعمل وبين الأهداف المعلنة للتدريب، لأن التدريب

بكل برابجه يجب أن يكون بناء على تحديد احتياجات تدريبية واقعية وفقا لاحتياجات سوق العمل ووفقا للمتغيرات المتلاحقة في

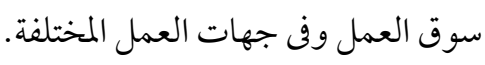

3/3- المزايا التى تحصل عليها عينة الدراسة بعد الحصول على البرامج التدريبية فى جهة العمل: للتعرف على المزايا التى تحصل عليها عينة الدراسة بعد الحصول على البرامج التدريبية فى جهة العمل، تم سؤاهم عن

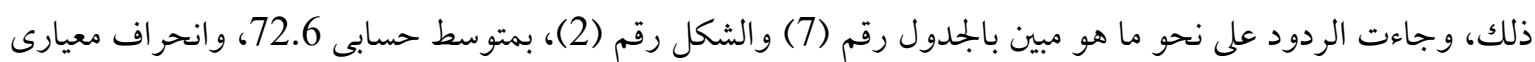
34.1 أن 145 أخصائي معلومات ونسبتهم 82.9٪ يقرون بأن جعلهم أكثر معرفة ومهارة عن باقى الزملاء هى من دمث أولى المزايا التى يحصلون عليها بعد الخصول على البرامج التدريبية فى جهة العمل.

الجدول رقم (7) المزايا التى يحصل عليها عينة الدراسة بعد الحصول على البرامج التدرييية فى جهة العمل

\begin{tabular}{|c|c|c|}
\hline النسبة المئوية & 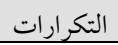 & المز ايا التى تحصل عليها عينة الدراسة بعد الحصول على البرامج التدريبية في جهة العمل \\
\hline$\% 82.9$ & 145 & تجعلنى أكثر معرفة ومهارة عن باقى الزملاء \\
\hline$\% 56.6$ & 99 & زيادة الدقة في انجاز المهام \\
\hline$\% 35.4$ & 62 & تفيدنى عند الترقى \\
\hline$\% 32.6$ & 57 & ابتكار أساليب جديدة في العمل \\
\hline$\% 31.4$ & 55 & تقليل الهدر في وقت العمل \\
\hline$\% 26.9$ & 47 & تنمية قدرات الإبداع والابتكار \\
\hline$\% 24.6$ & 43 & مزايا مادية \\
\hline- & 72.6 & المتوسط حسابي \\
\hline- & 34.1 & الانحر اف معيارى \\
\hline
\end{tabular}

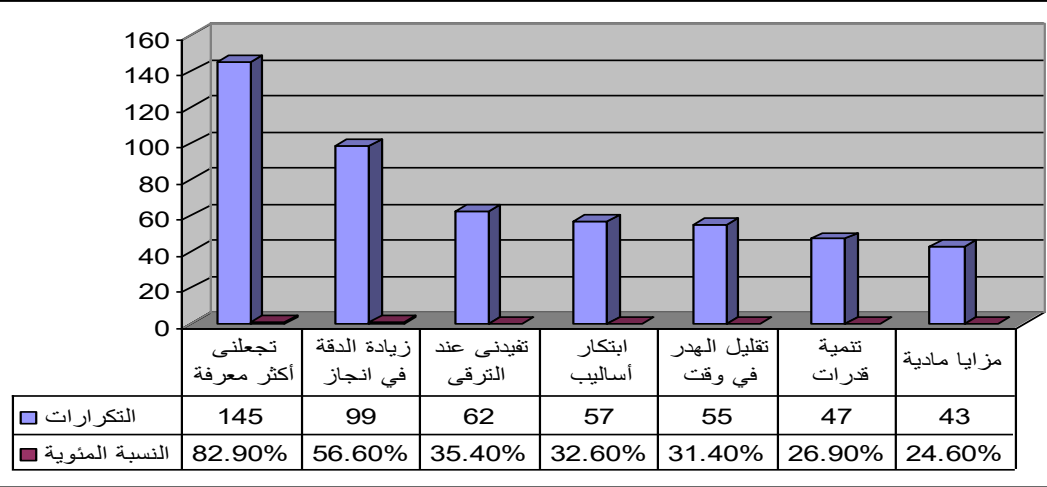

الشكل رقم (2) المزايا التى يحصل عليها عينة الدراسة بعد الحصول على البرامج التدريبية فى جهة العمل

ويأتى فى المرتبة الثانية ميزة زيادة الدقة فى إنجاز المهام وقد أقر بها 99 أخصائي معلومات بنسبة 56.6٪، في حين أقر 62

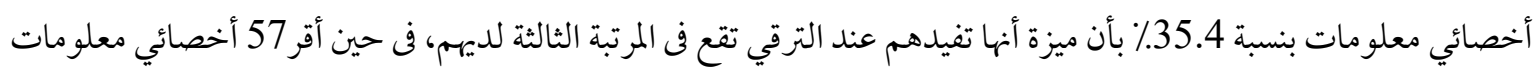
بنسبة 62.6٪ بأن ميزة ابتكار أساليب جديدة في العمل تقع فى المرتبة الرابعة لديهه، فى حين جاء في المرتبة الخامسة ميزة تقليل

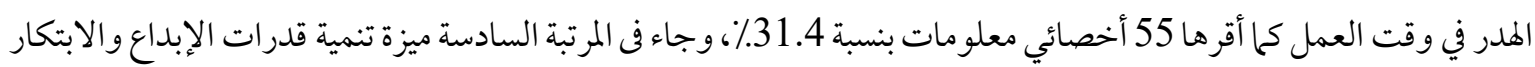


كما أقرها 47 أخصائي معلو مات بنسبة 26.9٪، وجاءت الميزة المادية فى المرتبة الأخيرة وقد أقرها 43 أخصائي معلومات بنسبة $\% 24.6$

ونستتج من ذلك أن ترتيب هذه الميزات كما أقرها أخصائيو المعلومات تتفق مع تعريف (عبد الرحمن توفيق) بأن التدريب

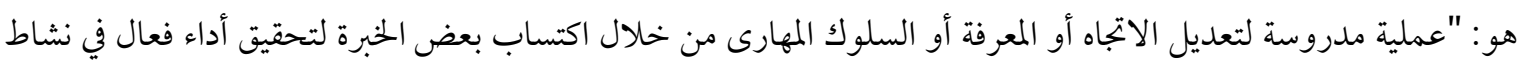
واحد أو بجموعة من الأنشطة ويتمثل الهدف من هذه العملية في المواقف الخاصة بالعمل في تنمية قدرات الأفراد وفي تلبية احتياجات الأشخاص العاملين في المؤسسة في الوقت الحاضر وفي المستقبل(توفيق ،2011م)." فالتدريب عبارة عن أسلوب منظم يتم بواسطته زيادة معرفة الفرد ومهار اته وقدر اته وذلك من أجل هدف محدد (2003, Dale).

\section{رابعا/ مدى الإفادة من البرامج التدريبية التى حصلت عليها عينة الدراسة:}

نظر الطبيعة هذه الدراسة ، وطبيعة موضوع البحث وهو دراسة الاحتياجات التدريبية الخاصة بالمهارات الحياتية لدى أخصائيي المعلومات فى المكتبات الأكاديمية بجامعة المنوفية فيجب أن نتطرق إلى معرفة مدى الإفادة من البرامج التدريبية التى تم

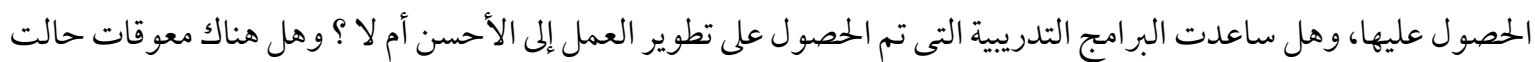

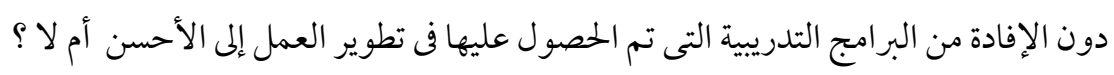

1/4- مدى إفادة عينة الدراسة من البرامج التدريبية التى تم الحصول عليها: للتعرف على مدى إفادة عينة الدراسة من البرامج التدريبية التى تم الحصول عليها، تم سؤالهم عن ذلك، وجاءت الردود على نحو ما هو مبين بالجدول رقم (8) .

الجدول رقم (8) مدى إفادة عينة الدراسة من البرامج التدريبية التى تم الحصول عليها

\begin{tabular}{|c|c|c|}
\hline 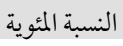 & 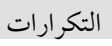 & مدى إفادة عينة الدراسة من البرامجج التدريبية التى تم الحصول عليها \\
\hline$\% 14.3$ & 25 & متناز (100) \\
\hline$\% 46.9$ & 82 & جيد جدا (75/\%) \\
\hline$\% 38.9$ & 68 & جيد (50\%-75\%) \\
\hline- & - & ضعيف (25\% - 50\%) \\
\hline- & - & ضعيف جدا ( أقل من 25\% - 0\%) \\
\hline- & - & - لا أستفيد منها على الإطلاق \\
\hline$\% 100$ & 175 & المجموع \\
\hline
\end{tabular}

يشير الجدول رقم (8) إلى مدى إفادة عينة الدراسة من البرامج التدريبية التى تم الحصول عليها هو جيد جدا (75٪) حيث أشار 82 أخصائي معلومات بنسبة 46.9٪ إلى ذلك، فى حين أشار 68 أخصائي معلومات بنسبة 38.9٪ لمدى إفادة عينة الدراسة من البرامج التدريبية التى تم الحصول عليها هو جيد (50\%- 75٪) فى حين أشار 25 أخصائي معلومات بنسبة 38.9٪ إلى مدى إفادة عينة الدراسة من البرامج التدريبية التى تم الحصول عليها هو ممتاز (100٪) . ونستنتج من ذلك أن أكثر نسبة إفادة من من تطبيق واتس آب من البرامج التدريبية التى تم الحصول عليها هو جيد جدا (75\%)، و أقلها هو ممتاز بنسبة (100\%)، وهذا يدل على استفادة عينة الدراسة بدرجة كبيرة من البرامج التدريبية التى تم الخصول عليها، ولكن هناك بعض القصور أدى إلى عدم الوصول إلى نسبة100٪٪، ويجب أن يعمل المسئولون عن المكتبات الأكاديمية 
بجامعة المنوفية على ارتفاع الفائدة من التدريب والعمل على تحديد الاحتياجات التدريبية لأخصائيي المعلومات الفعلية لتحقيق أقصى درجة إفادة مكنة من البرامج التدريبية .

2/4- مدى مساعدة البرامج التدريبية التى حصلت عليها عينة الدراسة على تطوير العمل إلى الأحسن: للتعرف على مدى مساعدة البرامج التدريبية التى حصلت عليها عينة الدراسة على تطوير العمل إلى الأحسن، تم سؤالهم

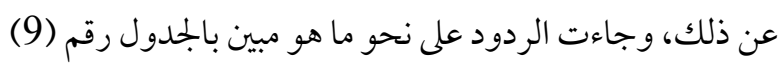

الجدول رقم (9) مدى مساعدة البرامج التدريبية التى حصلت عليها عينة الدراسة على تطوير العمل إلى الأحسن

\begin{tabular}{|c|c|c|}
\hline 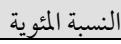 & 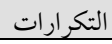 & ية التى حصلت عليها عينة الدراسة على تطوير العمل إلى الأحسن \\
\hline$\%$.76.6 & 134 & نعم \\
\hline$\% .23 .4$ & 41 & $\mathrm{y}$ \\
\hline$\% 100$ & 175 & 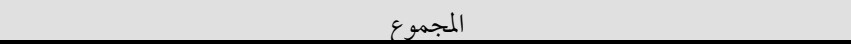 \\
\hline
\end{tabular}

أشار الجدول رقم (9) لنسبة كبيرة من عينة الدراسة بواقع 76.6٪ وبلغ عددهم 134 أخصائي معلومات أقروا بأن

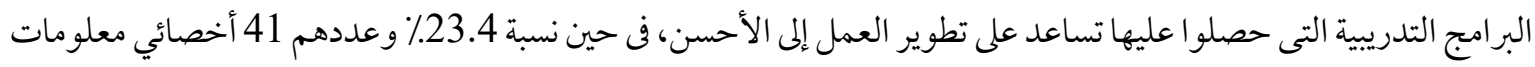

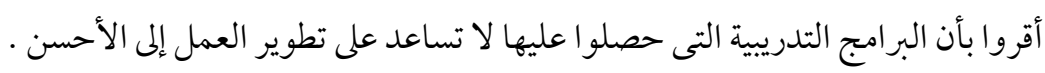

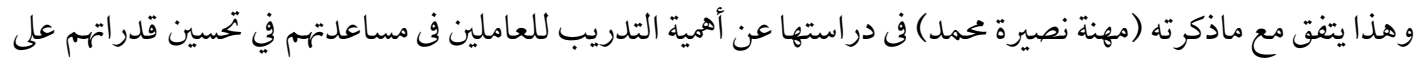

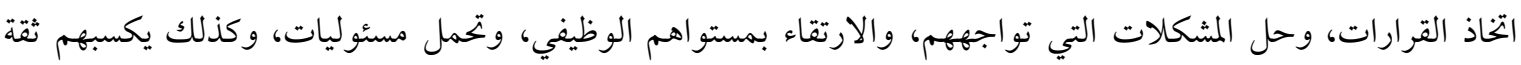

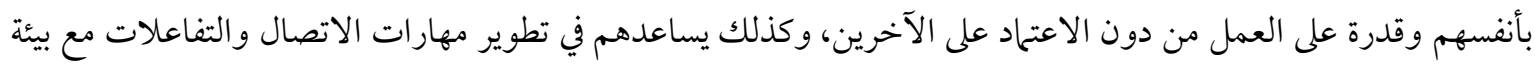
العمل بها يجقق الأداء الفاعل، وينمي التدريب لديهم أيضا المرونة والقدرة على التكيف في حياتهم العملية. (محمد، ،2014م).

3/4- معوقات الإفادة من البرامج التدريبية التى حصلت عليها عينة الدراسة فى تطوير العمل إلى الأحسن: للتعرف على المعوقات التى حالت دون الإفادة من البرامج التدريبية التى حصلت عليها عينة الدراسة فى تطوير العمل

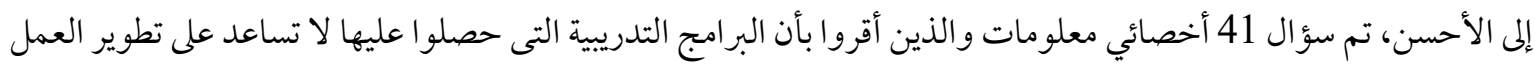

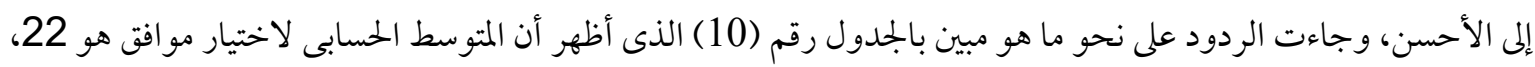

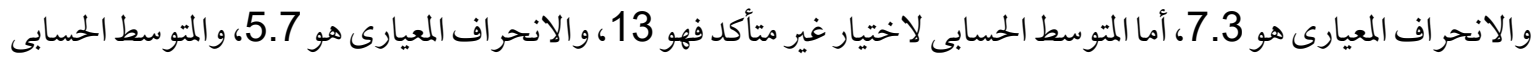
لاختيار معارض هو 6، والانحراف المعيارى هو 1.6.

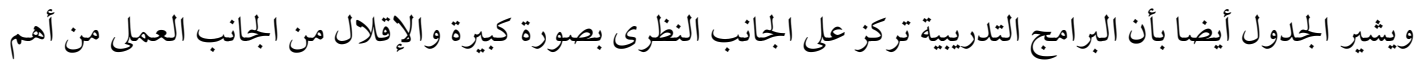

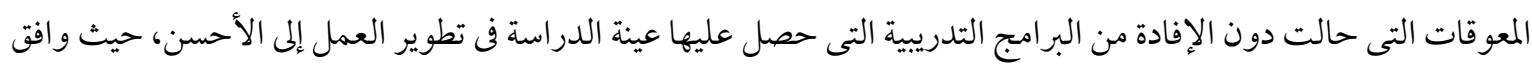

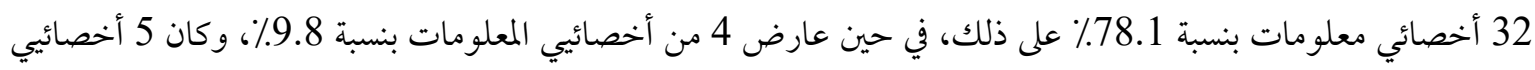

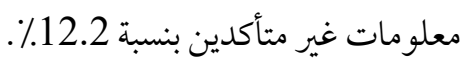


الجدول رقم (10) المعوقات التى حالت دون الإفادة من البرامج التدريبية التى حصلت عليها عينة الدراسة فى تطوير العمل إلى الأحسن

\begin{tabular}{|c|c|c|c|c|c|c|c|c|}
\hline \multicolumn{8}{|c|}{ الإختيارات } & \multirow{2}{*}{ 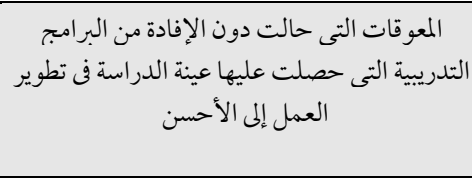 } \\
\hline 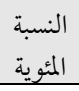 & المجموع & $\%$ & معارض & $\%$ & غير متأكد & $\%$ & موافق & \\
\hline$\% 100$ & 41 & 9.8 & 4 & 12.2 & 5 & 78.1 & 32 & - بصورة البرامج التدريبية تركز على الجانب النظرى الإقلال من الجانب العملى \\
\hline$\% 100$ & 41 & 14.6 & 6 & 39.1 & 16 & 46.3 & 19 & - نظام العمل لا يساعد على تطبيق ما تم التدريب \\
\hline$\% 100$ & 41 & 19.5 & 8 & 43.9 & 18 & 36.9 & 15 & - محاربة الزملاء فى العمل للتغيير \\
\hline- & - & - & 6 & - & 13 & - & 22 & المتوسط حسابي \\
\hline - & - & - & 1.6 & - & 5.7 & - & 7.3 & الانحراف المعيارى \\
\hline
\end{tabular}

كما أشار 19 أخصائي معلومات بنسبة 46.3\% إلى نظام العمل لا يساعد على تطبيق ما تم التدريب عليه من أهم المعوقات التى حالت دون الإفادة من البرامج التدريبية التى حصلت عليها عينة الدراسة فى تطوير العمل إلى الأحسن، في حين عارض 6 أخصائيي معلومات بنسبة 14.6٪، وكان 16 أخصائي معلومات غير متأكدين بنسبة 39.1٪ كما أشار 15 أخصائي معلومات بنسبة 36.9٪ إلى محاربة الزملاء فى العمل للتغيير من أهم المعوقات التى حالت دون الإفادة من البرامج التدريبية التى حصلت عليها عينة الدراسة فى تطوير العمل إلى الأحسن ، في حين عارض 8 أخصائيي معلومات بنسبة 19.5\%، وكان 18 أخصائي معلومات غير متأكدين بنسبة 43.9٪. ونستنتج من ذلك أنَّ من أهم المعوقات التى حالت دون الإفادة من البرامج التدريبية التى حصلت عليها عينة الدراسة فى تطوير العمل إلى الأحسن هو تركيز البرامج التدريبية على الجانب النظرى بصورة كبيرة والإقلال من الجانب العملى، وهذا يتفق مع أهم أسباب فشل البرامج التدريبة وهو: الدورة التدريبية نظرية جدا فقد يكون المدرب على دراية بالخلفية النظرية لموضوع

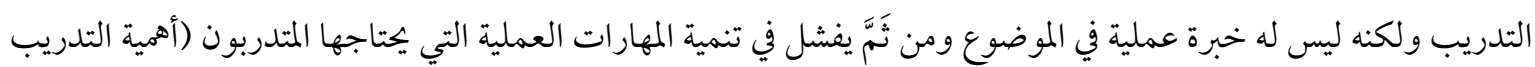
والدورات التدريبية فى المؤسسات،2016م) .

\section{خامسا/ الاحتياجات التدريبية المستقبلية الخاصة بتنمية الموارد البشرية :}

في هذه الجزئية من الدراسة سنتطرق إلى تحديد الاحتياجات التدريبية الخاصة بتنمية الموارد البشرية بجهة العمل، والطرق

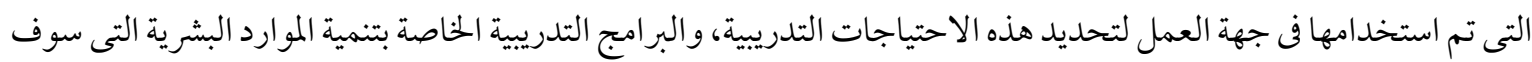
يتم إعداد دورات تدريبية فيها، والطرق والأساليب التدريبية التى تفضلها عينة الدراسة في الدورات التدريبية الخاصة بتنمية الموارد البشرية التى يريدون الحصول عليها، و الصفات التى يجب أن يتمتع بها مدرب تنمية الموارد البشرية لكى تتحقق الفائدة القصوى بتئي من التدريب، و الطرق التى يرغيها عينة الدراسة لتقييم أدائهم أثناء الحصول على الدورات التدريبية الخاصة بتنمية الموارد البشرية. 
1/5-1/إسهام الدورات التدريبية الخاصة بتنمية الموارد البشرية فى رفع الجدارات (القدرات المعرفية والمهارية والاتجاهات) الخاصة بعينة الدراسة فى مجال العمل:

للتعرف على وجهة نظر عينة الدراسة فى إسهام الدورات التدريبية الخاصة بتنمية الموارد البشرية فى رفع الجدارات: (القدر ات المعرفية والمهارية والاتجاهات) الخاصة بعينة الدراسة في مجال العمل تم سؤ الهم عن ذلك، وجاءت الردود على نحو ما هو مبين بالجدول رقم (11).

الجدول رقم (11) إسهام الدورات التدريبية الخاصة بتنمية الموارد البشرية فى رفع الجدارات: (القدرات المعرفية والمهارية والاتجاهات) الخاصة بعينة الدراسة فى مجال العمل

\begin{tabular}{|c|c|c|}
\hline النسبة المئوية & التكرارات & إسهام الدورات التدريبية الخاصة بتنمية الموارد البشرية فى رفع الجمدارات (القدرات المعرفية والمهارية والإتجاهات) \\
\hline$\% 93.1$ & 163 & نعم \\
\hline$\% 6.9$ & 12 & ل \\
\hline$\% 100$ & 175 & المججموع \\
\hline
\end{tabular}

يشير الجدول رقم (11) إلى 163 أخصائي معلومات بنسبة 93.1٪ أقروا بأن الدورات التدريبية الخاصة بتنمية الموارد البشرية تسهم فى رفع الجدارات: (القدرات المعرفية والمهارية والاتجاهات) الخاصة لمم فى بجال العمل، في حين أقر 12 أخصائي معلومات بنسبة 6.9٪ أقروا بأن الدورات التدريبية الخاصة بتنمية الموارد البشرية لا تسهم فى رفع الجلدارات: (القدرات المعرفية و المهارية والاتجاهات) الخاصة لهم فى مجال العمل.

ونستنتج من ذلك أن 93.1٪ من عينة الدراسة لديهم وعي بأهمية دورات تنمية الموارد البشرية بأنها تكسبهم معارف ومهارات وتغير اتجاهاتهم، فالتدريب يجب أن يغطي ما يحتاج إليه المتدرب من معلومات تساعده مباشرة في أداء وظيفته،

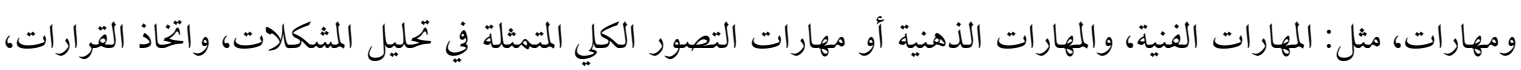
و التخطيط الإستراتيجي، وإدارة الاجتماعات، والمهارات الإنسانية ، واتجاهات إيجابية من خلال تأييد سياسة المنظمة، والدفاع عنها والتعاون مع الزملاء والرؤساء، وتنمية روح العمل الجماعي(سلطان ،2009م) ،والشعور بالمسئولية بكل ما له علاقة

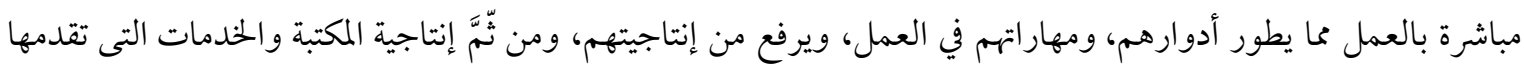

2/5- البرامج التدريبية الخاصة بتنمية الموارد البشرية التى ترغب عينة الدراسة فى إعداد دورات تدريبية فيها وتصسين جداراتهم :

للتعرف على البرامج التدريبية الخاصة بتنمية الموارد البشرية التى ترغب عينة الدراسة فى إعداد دورات تدريبية فيها وتحسين جداراتهم تم سؤالهم عن ذلك، وجاءت الردود على نحو ما هو مبين بالجدول رقم (12). يوضح الجدول رقم (12) البرامج التدريبية الخاصة بتنمية الموارد البشرية التى ترغب عينة الدراسة فى إعداد دورات

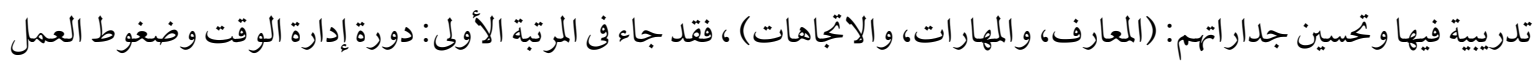
داخل البيئة الداخلية والخارجية للمكتبات الأكاديمية بواقع 88\% وبلغ عددهم 154 أخصائي معلومات منهم 112 أخصائي 
معلومات بنسبة 72.7٪ يريدون هذه الدورة لمدة ثلاثة أيام، و28 أخصائي معلومات بنسبة 18.2٪ يريدون هذه الدورة لمدة يوم

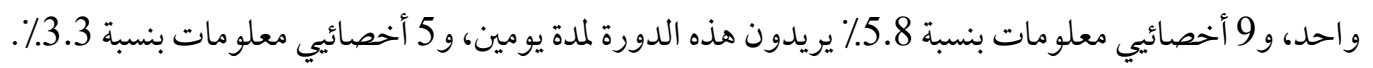

\section{الجدول رقم (12) البرامج التدريبية الخاصة بتنمية الموارد البشرية التى ترغب عينة الدراسة فى إعداد دورات تدريبية فيها وتحسين جداراتهم}

\begin{tabular}{|c|c|c|c|c|c|c|c|c|c|c|}
\hline \multicolumn{8}{|c|}{ الفترة الزمنية } & \multirow[t]{3}{*}{$\%$} & \multirow{3}{*}{ التكرارات } & \multirow{3}{*}{ اسم البرنامج التدريبى } \\
\hline \multicolumn{2}{|c|}{ أربعة أيام لمدة } & \multicolumn{2}{|c|}{ ثلاثة أيام لمدة 18} & \multicolumn{2}{|c|}{ يومان لمدة 12 ساعة } & \multicolumn{2}{|c|}{ يوم واحد لمدة 6} & & & \\
\hline$\%$ & التكرارات & $\%$ & التكرارا & $\%$ & التكرارات & $\%$ & التكرارات & & & \\
\hline 3.3 & 5 & 72.7 & 112 & 5.8 & 9 & 18.2 & 28 & 88 & 154 & 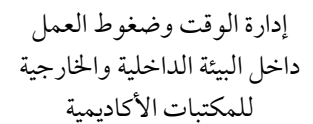 \\
\hline 80.3 & 98 & 19.7 & 24 & & & & & 69.7 & 122 & الخدمات المكتبية للمستفيديد الإبداعى تقديم \\
\hline 39.3 & 44 & 51.8 & 58 & 8.9 & 10 & & & 64 & 112 & 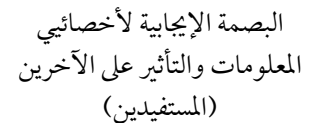 \\
\hline \multirow[t]{2}{*}{17.3} & 19 & 69.1 & 76 & 13.6 & 15 & & & 62.9 & 110 & منهجية التغير وتطوير الذات عند أخصائي المعلومات \\
\hline & & 16.5 & 18 & 22.9 & 25 & 60.6 & 66 & 62.3 & 109 & 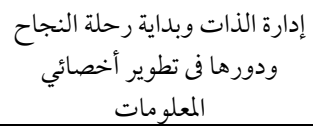 \\
\hline 69.5 & 75 & 6.5 & 7 & 8.3 & 9 & 15.7 & 17 & 61.7 & 108 & المهارات الحياتية ودورها فلى جودة الخدمات المعلوماتية \\
\hline 24.8 & 26 & & & & & 75.2 & 79 & 60 & 105 & مفاتيح السعادة عند أخصائيي \\
\hline 4 & 4 & 86.1 & 87 & 9.9 & 10 & & & 57.7 & 101 & 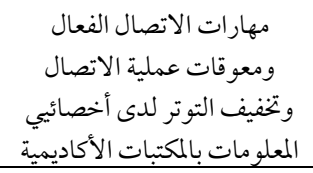 \\
\hline 76.7 & 76 & 10.1 & 10 & 8.1 & 8 & 5.1 & 5 & 56.6 & 99 & 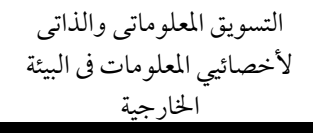 \\
\hline
\end{tabular}

وجاء فى المرتبة الثانية: دورة التفكير الإبداعى فى تقديم الخدمات المكتبية للمستفيدين بواقع 69.7 ٪ وبلغ عددهم 122 أخصائي معلومات منهم 98 أخصائي معلومات بنسبة 80.3 ٪ يريدون هذه الدورة لمدة أربعة أيام، و24 أخصائي معلومات بنسبة 19.7\% يريدون هذه الدورة لمدة ثلاثة أيام. وجاء في المرتبة الثالثة: دورة البصمة الإيجابية لأخصائيي المعلومات والتأثير على الآخرين(المستفيدين) بو اقع 64 ٪ وبلغ عددهم 112 أخصائي معلو مات منهم 58 أخصائي معلومات بنسبة 51.8 ٪ يريدون هذه الدورة لمدة ثلاثة أيام، و44 أخصائي

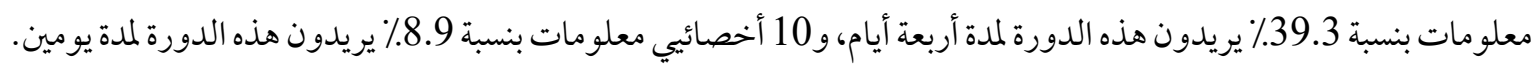




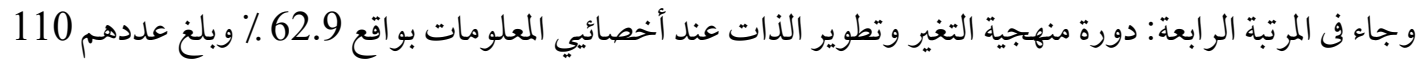

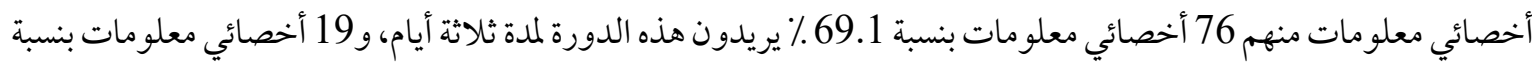

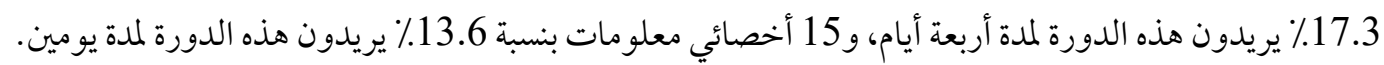

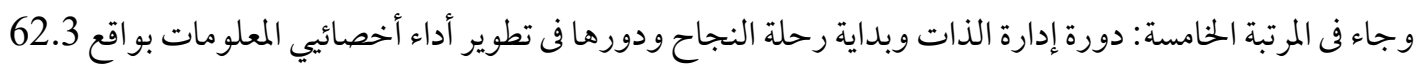

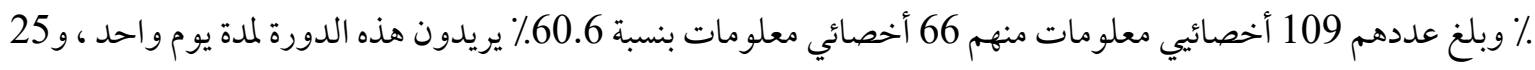

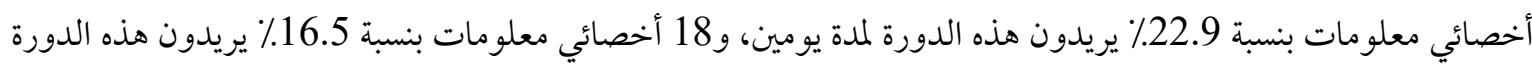
لمدة ثلاثة أيام.

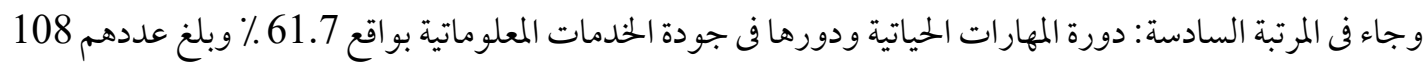

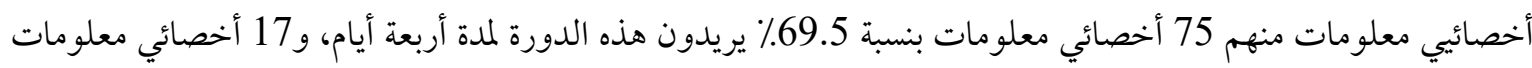

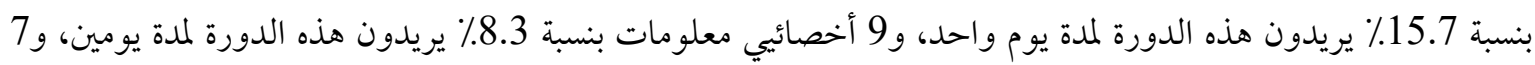

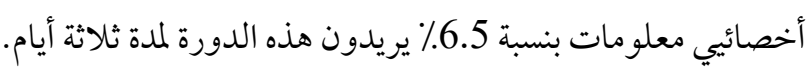

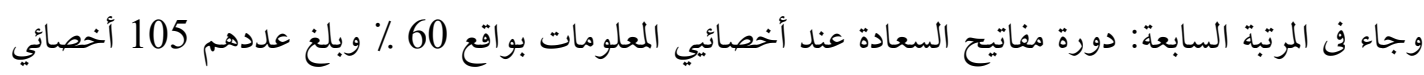

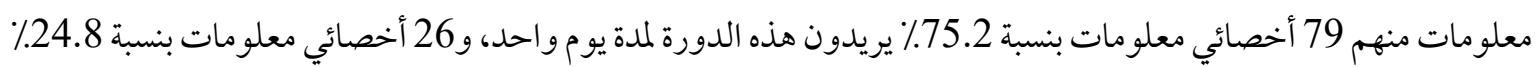

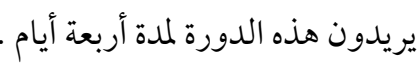
وجاء في المرتبة الثامنة: دورة مهارات الاتصال الفعال ومعوقات عملية الاتصال وتخفيف التوتر لدى أخصائيي

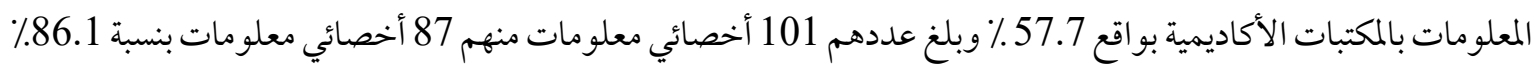

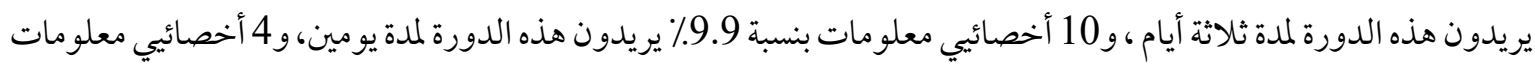

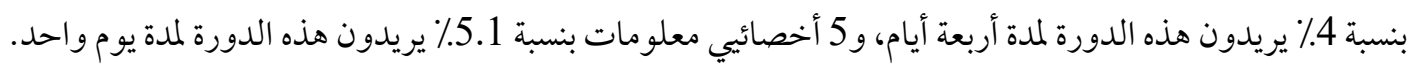

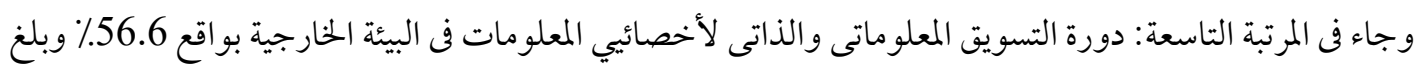

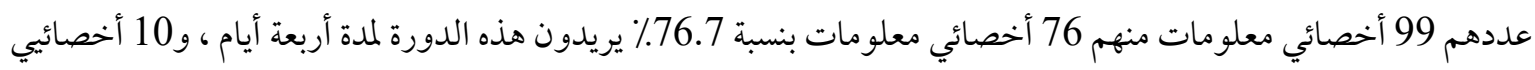

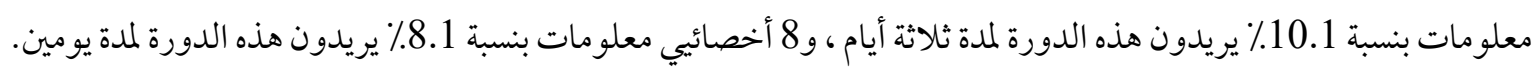

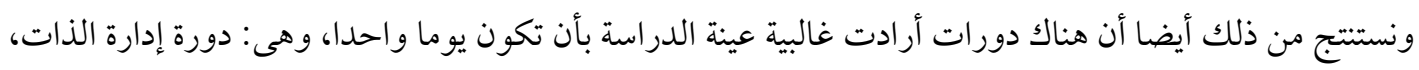

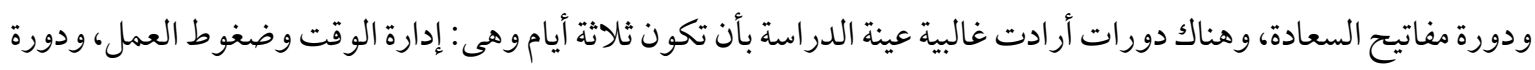

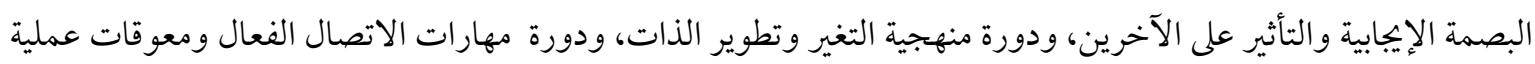

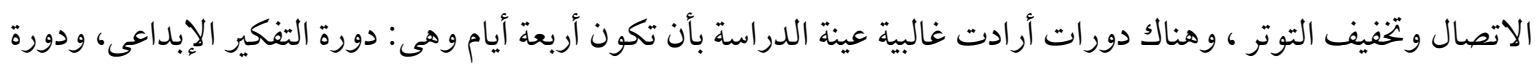
المهارات الحياتية، ودورة التسويق المعلوماتى والذاتى. 


\section{3/5- الطرق والأساليب التدريبية التى تفضلها عينة الدراسة فى الدورات التدريبية الخاصة بتنمية الموارد البشرية التى يرغبون فى الحصول عليها:}

للتعرف على الطرق والأساليب التدريبية التى تفضلها عينة الدراسة فى الدورات التدريبية الخاصة بتنمية الموارد البشرية التى يرغبون فى الحصول عليها وتحسين الجدارات لديهم، تم سؤالهم عن ذلك، وجاءت الردود على نحو ما هو مبين بالجدول رقم (13). بمتوسط حسابى لاختيار موافق هو 105، والانحر اف المعيارى هو 33.5، أما المتوسط الحسابى لاختيار غير متأكد فهو

38.8، والانحراف المعيارى هو 19.1، والمتوسط الحسابى لاختيار معارض هو 31.2 ، والانحر اف المعيارى هو 16.8. وكذلك يشير الجدول إلى جماعات النقاش أفضل الطرق والأساليب التدريبية التى تفضلها عينة الدراسة فى الدورات التدريبية الخاصة بتنمية الموارد البشرية التى يرغبون في الحصول عليها، حيث وافق 151 أخصائي معلومات بنسبة 86.3٪ على إنى

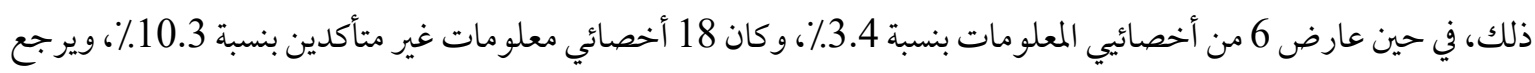
ذلك لأنه أسلوب تدريبي يتم فيه طرح موضوع ما من قبل المدرب، وتتم مناقشته بشكل تشاركي مع المشاركين و الوصول إلى مئل استنتاجات ومقترحات تغني هذا الموضوع، عند إجراء المناقشات يتم استخدام نوعين من الأسئلة: الأسئلة المفتوحة، والأسئلة المغلقة (دليل المدرب،2014م).

\section{الجدول رقم (13) الطرق والأساليب التدريبية التى تفضلها عينة الدراسة}

فى الدورات التدريبية الخاصة بتنمية الموارد البشرية التى يرغبون فى الحصول عليها

\begin{tabular}{|c|c|c|c|c|c|c|c|c|}
\hline \multicolumn{8}{|c|}{ الاختيارات } & \multirow{2}{*}{ 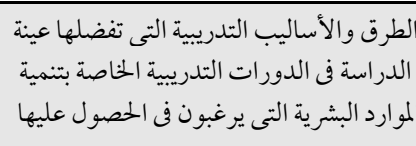 } \\
\hline النسبة المئوية & المجموع & $\%$ & معارض & $\%$ & غير متأكد & $\%$ & موافق & \\
\hline$\% 100$ & 175 & 3.4 & 6 & 10.3 & 18 & 86.3 & 151 & - - جماعات النقاش \\
\hline$\% 100$ & 175 & 4 & 7 & 13.1 & 23 & 82.9 & 145 & - - ورش العمل \\
\hline$\% 100$ & 175 & 11.4 & 20 & 9.1 & 16 & 79.4 & 139 & - العصف الذهنى \\
\hline$\% 100$ & 175 & 6.9 & 12 & 17.1 & 30 & 76 & 133 & - - دراسة الحالة \\
\hline$\% 100$ & 175 & 16 & 28 & 13.1 & 23 & 70.9 & 124 & - المحاضرات \\
\hline$\% 100$ & 175 & 22.9 & 40 & 18.9 & 33 & 58.3 & 102 & - فكر ثم شارك ثم ناقش( TPS) \\
\hline$\% 100$ & 175 & 25.7 & 45 & 23.4 & 41 & 50.9 & 89 & - التحدث عن قصة \\
\hline$\% 100$ & 175 & 25.1 & 44 & 28 & 49 & 46.9 & 82 & - لعب الأدوار \\
\hline$\% 100$ & 175 & 21.1 & 37 & 37.1 & 65 & 41.7 & 73 & - التكليفات \\
\hline$\% 100$ & 175 & 32 & 56 & 29.7 & 52 & 38.3 & 67 & - المحاكاة \\
\hline$\% 100$ & 175 & 27.4 & 48 & 44 & 77 & 28.6 & 50 & - المناظرة \\
\hline - & - & - & 31.2 & - & 38.8 & - & 105 & المتو سط الحسابي \\
\hline - & - & - & 16.8 & - & 19.1 & - & 33.5 & الانحراف المعيارى \\
\hline
\end{tabular}

كما أشار 145 أخصائي معلومات بنسبة 82.9٪ إلى ورش العمل ثانى أفضل الطرق والأساليب التدريبية التى تفضلها عينة الدراسة في الدورات التدريبية الخاصة بتنمية الموارد البشرية التى يرغبون في الحصول عليها ، في حين عارض 7 أخصائيي معلومات بنسبة 4\%، و كان 23 أخصائي معلومات غير متأكدين بنسبة 13.1٪ كما أشار 139 أخصائي معلومات بنسبة 79.4٪ إلى العصف الذهنى ثالث أفضل الطرق والأساليب التدريبية التى تفضلها عينة الدراسة في الدورات التدريبة الخاصة بتنمية الموارد البشرية التى يرغبون في الحصول عليها ، في حين عارض 20 
أخصائي معلومات بنسبة 11.4٪، وكان 16 أخصائي معلومات غير متأكدين بنسبة 9.1\%، ويرجع ذلك لأن هذا الأسلوب

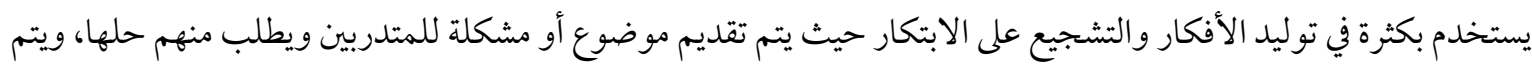

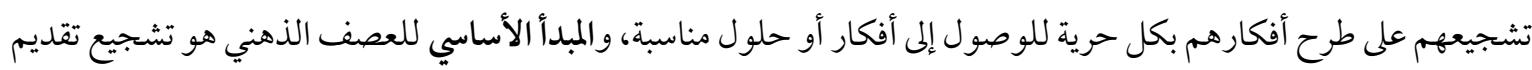

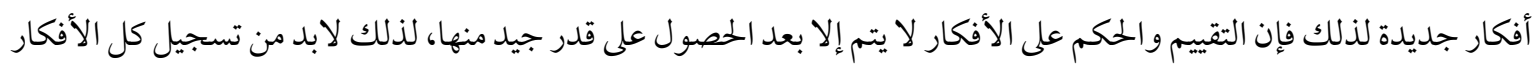

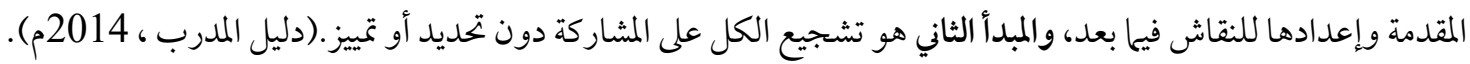

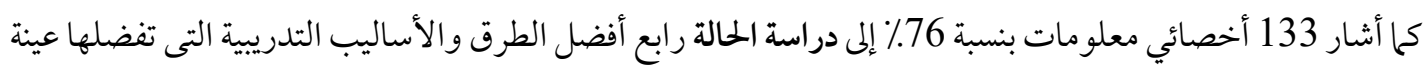

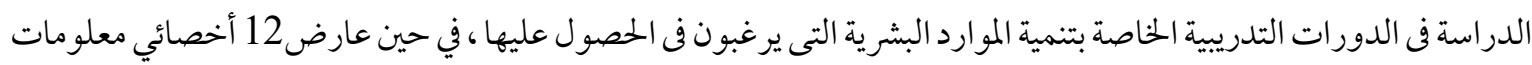

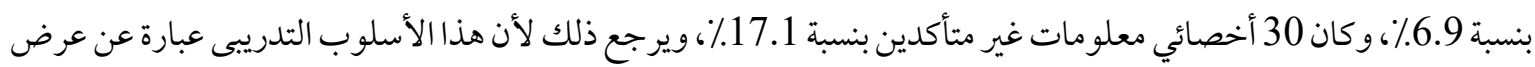

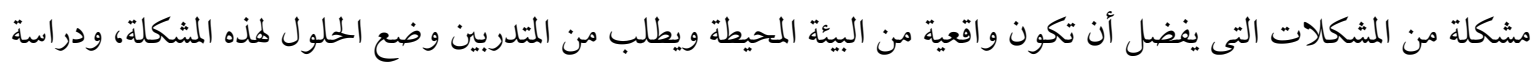

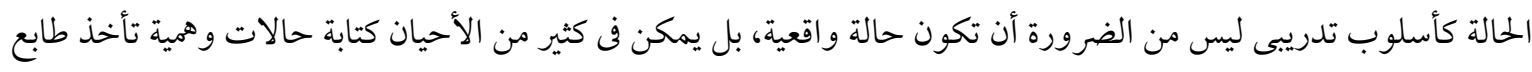

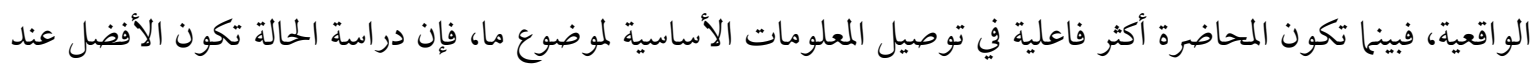

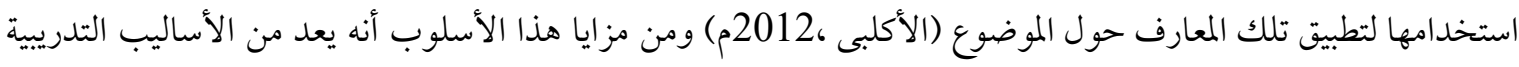

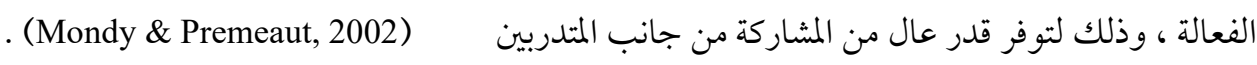
كما أشار 124 أخصائي معلومات بنسبة 70.9٪ إلى المحاضرات خامس أفضل الطرق والأساليب التدريبية التى تفضلها

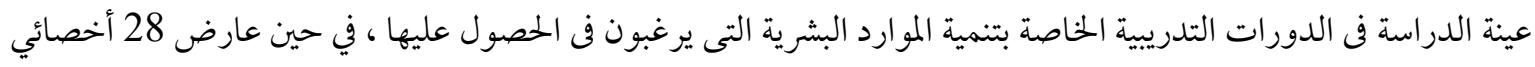

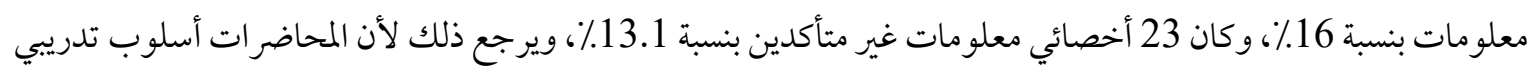

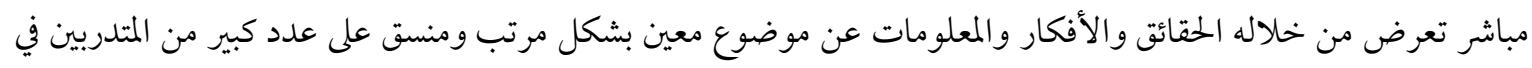

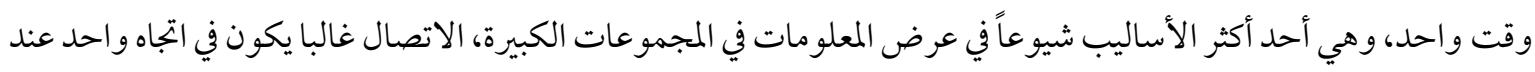

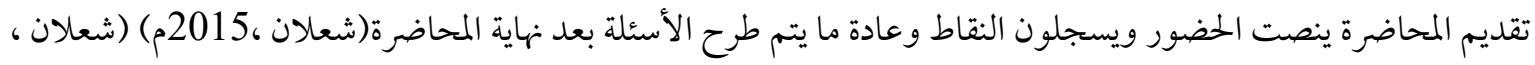

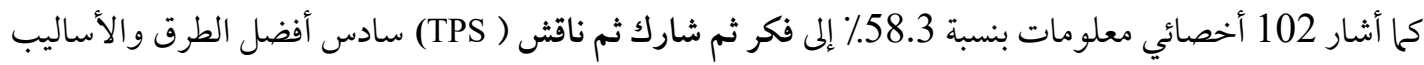

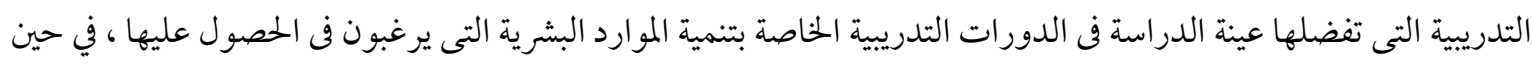

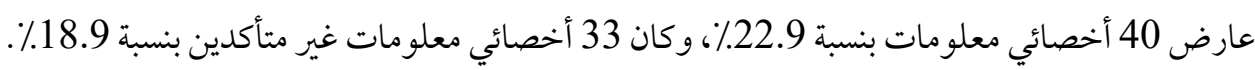

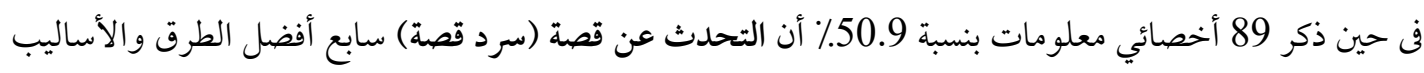

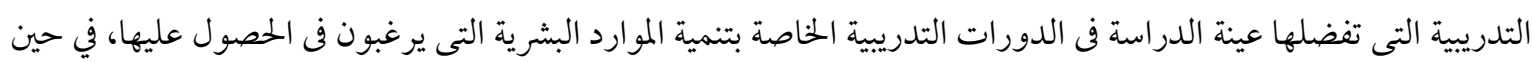

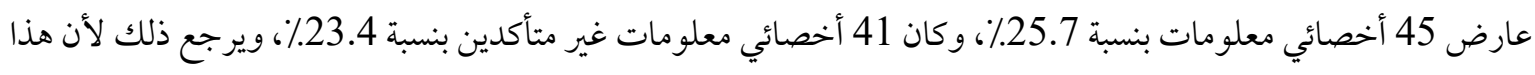

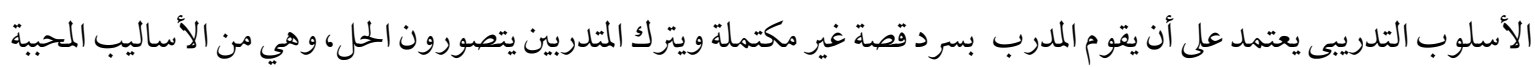

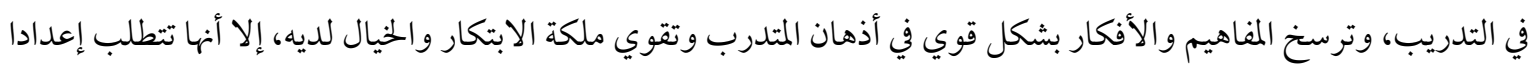

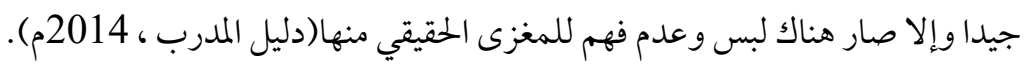


فى حين ذكر 82 أخصائي معلو مات بنسبة 46.9٪ أن لعب الأدوار ثامن أفضل الطرق والأساليب التدريبية التى تفضلها عينة الدراسة فى الدورات التدريبية الخاصة بتنمية الموارد البشرية التى يرغبون فى الحصول عليها ، في حين عارض 44 حأخسئي أخصائي معلو مات بنسبة 25.1٪، و كان 49 أخصائي معلومات غير متأكدين بنسبة 28٪، ويرجع ذلك لأن هذا الأسلوب التدريبي يقوم فيه المتدربون بأداء وضع افتراضي أو حقيقي أمام الحضور ويتم إعطاء المتدربين الخلفية الضرورية وبعض الأفكار حول كيفية تنظيم أدوارهم ولكن ليس هناك حوار أو نص محدد بل يتم توليد ذلك أثناء لعب الأدوار، وبعد نهاية العرض يقوم المشاهدون و المشاركون معاً بمناقشة الأمر، فمعظم الناس معتادون على فكرة لعب الأدوار من موقع سلبي (مشاهدة العروض على التليفزيون)، ومن ثم فإن مشاركتهم في لعب الأدوار خلال التدريب يوضح اهتماماتهم، ويحث مشاركتهم الوجدانية وكذلك يطور تلقائيتهم ومهار اتهم

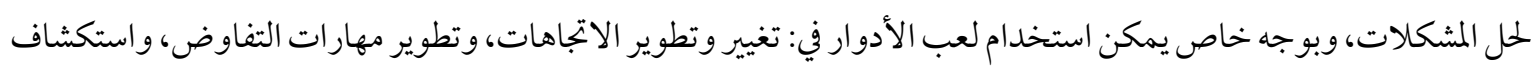
العلاقات الإنسانية الضعيفة، وإظهار الجو انب الاجتحاعية والسياسية للأوضاع، وتعزيز التعلم من خلال العمل وارتكاب الأبطاء (توفيق ، 2006م).

فى حين ذكر 73 أخصائي معلومات بنسبة 41.7٪ أن التكليفات تاسع أفضل الطرق والأساليب التدريبية التى تفضلها

عينة الدراسة في الدورات التدريبة الخاصة بتنمية الموارد البشرية التى يرغبون في الحصول عليها، في حين عارض 37 أخصائي

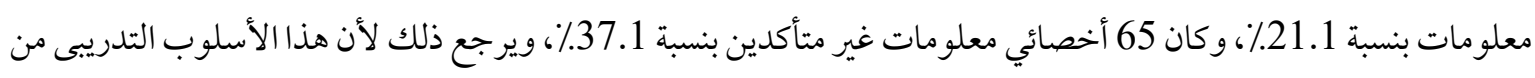
الأساليب الأكثر شيوعا حيث إنها من الأنشطة خارج قاعة التدريب وتستخدم التكليفات بهدف تعزيز التعلم الفردي، وإثراء

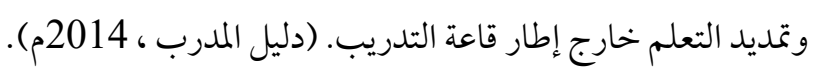
فى حين ذكر 67 أخصائي معلومات بنسبة 38.3٪ أن المحاكاة من الطرق والأساليب التدريبية التى تفضلها عينة الدراسة

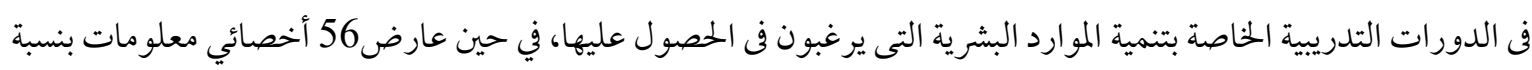

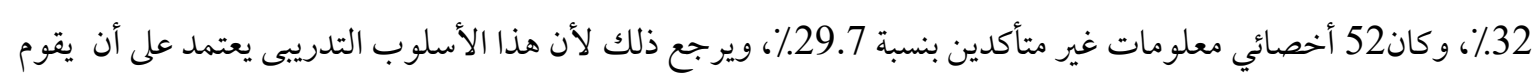

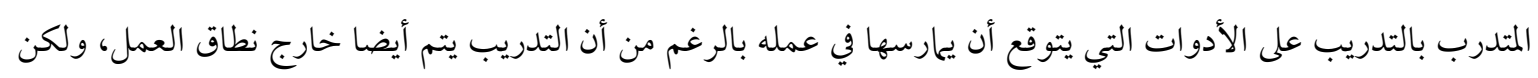
يتم خلق أو محاكاة الظروف التي سوف يعمل في ظلها الفرد، وتتميز هذه الطريقة بإمكانية تحقيق المزايا المترتبة على التدريب أثناء العمل بالإضافة إلى تقليل المخاطر المترتبة على إمكانية الممارسة الفعلية لبعض الوظائف، ويترتب على ذلك ما يلي : زيادة درجة

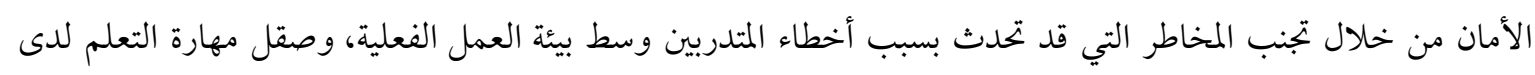

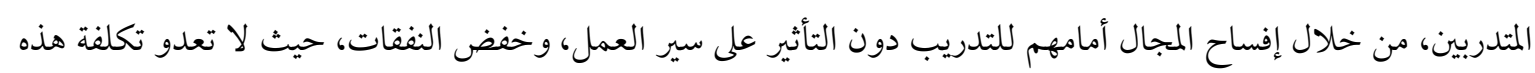
الطريقة إلا أن تكون مبالغ قليلة تشمل تكاليف الصيانة وإصلاح المعدات التي قد تتلف بسبب أخطاء المتدربين(محمد ، 2014م). فى حين ذكر 50 أخصائي معلومات بنسبة 28.6٪ أن المناظرة من الطرق والأساليب التدريبية التى تفضلها عينة الدراسة في الدورات التدريبة الخاصة بتنمية الموارد البشرية التى يرغبون في الحصول عليها ، في حين عارض 48 أخصائي معلومات بنسبة 27.4\%، وكان 77 أخصائي معلومات غير متأكدين بنسبة 44٪. 
4/5- الطرق التى ترغبها عينة الدراسة لتقييم أدائها أثناء الحصول على الدورات التدريبية الخاصة بتنمية الموارد

البشرية:

للتعرف على الطرق التى ترغبها عينة الدراسة لتقييم أدائها أثناء الحصول على الدورات التدريبية الخاصة بتنمية الموارد

البشرية تم سؤالهم عن ذلك، وجاءت الردود على نحو ما هو مبين بالجدول رقم (14) بمتوسط حسابى 111، وانحراف

معيارى28.1، الطرق التى ترغبها عينة الدراسة لتقييم أدائها أثناء الخصول على الدورات التدريبية الخاصة بتنمية الموارد البشرية ، فنجد أن 144 أخصائي معلومات ونسبتهم 82.3٪ يقرون أن التكليفات والأبحاث من أهم الطرق التى ترغبها عينة الدراسة

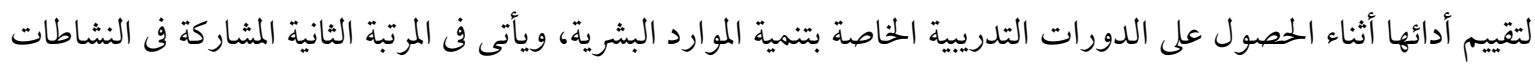

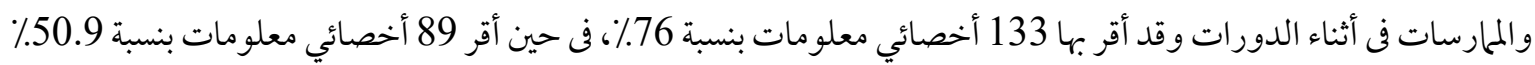

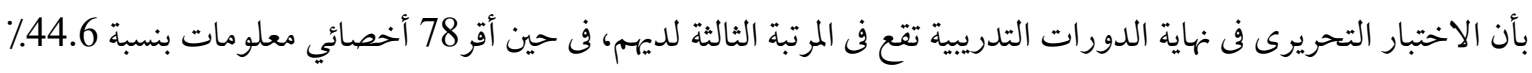
بأن الاختبار الشفهى يقع فى المرتبة الرابعة لديهم .

الجدول رقم (14)الطرق التى ترغبها عينة الدراسة لتقييم أدائها أثناء الحصول على الدورات التدريبية الخاصة بتنمية الموارد البشرية

\begin{tabular}{|c|c|c|}
\hline النسبة المئوية & التكرارات & الطرق التى ترغبها عينة الدراسة لتقييم أدائها أثناء الخصول على الدورات التدريبة الخاصة بتنمية الموارد \\
\hline$\% 82.3$ & 144 & تكليفات و أبحاث \\
\hline$\% 76$ & 133 & المشاركة في النشاطات والملمارسات في أثناء الدورات \\
\hline$\% .50 .9$ & 89 & اختبار تحريرى فى نهاية الدورات التدريبية \\
\hline$\% 44.6$ & 78 & اختبار شفهى \\
\hline- & 111 & المتوسط الحسابي \\
\hline- & 28.1 & الانحر اف المعياري \\
\hline
\end{tabular}

وهذه الطرق التى يتم استخدامها لتقييم أداء عينة الدراسة أثناء الحصول على الدورات التدريبية الخاصة بتنمية الموارد البشرية توضح مدى استيعابه للمعلومات ومدى اكتسابهم للمهارات ومدى تغيير اتجاهاتهم تجاه المواقف المختلفة، ومن ثم الوصول للهدف الرئيسي من هذا وهو تطوير العملية التدريبية.

5/5- المقترحات المستقبلية التى تتوقعها عينة الدراسة للمساعدة في تدقيق رسالة المكتبة وتفعيل التدريب بصفة عامة والتدريب الخاص بتنمية الموارد البشرية بصفة خاصة:

$$
\begin{aligned}
& \text { وعند سؤال عينة الدراسة عن ذلك ، جاءت الإجابات كما يلى: } \\
& \text { - مرورة إعداد دورات تدريبية مستمرة ومواكبة للتغيرات الحديثة. }
\end{aligned}
$$

- إعداد دورات تدريبية تخدم أخصائي المعلومات فى عمله وفى الخدمات التى يقدمها للمستفيدين. - التركيز على الجانب التطبيقى فى الدورات التدريبية أكثر من الشق النظرى لتحقيق الإفادة من البرامج التدريبية المقدمة لمم. - تحديد الاحتياجات التدريبة الفعلية سواء المهنية أو الخاصة بتنمية الموارد البشرية بدقة لأخصائي المعلومات، ومن ثم إعداد برامج تدريبية قائمة على هذه الاحتياجات لتحقيق الفائدة القصوى من التدريب. 
- الحرص على وجود مدربين معتمدين يستخدمون أكثر من أسلوب وطريقة فى التدريب ولديهم قدرة على الربط

$$
\text { بين الأهداف النظرية والتطبيقية للدورات، ولديهم تمكن من المحتوى العلمى للدورة . }
$$

\section{- الخطة التدريبية المقترحة المستقبلية والخاصة بالمهارات الحياتية وتصسين الجدارات لأخصائيي المعلومات فى المئ \\ المكتبات الأكاديمية بجامعة المنوفية :}

أصبح يشار حاليا إلى التأهيل والتدريب بأنها صناعة المستقبل حيث ازدادت أهميتها الإستراتيجية بالنسبة للمؤسسات المعلو ماتية بصفة عامة وللمكتبات بصفة خاصة، ومن ثم فمن الضروري أن يكون أخصائي المعلومات متشبعا بمهارات وخبرات كافية ومدرب تدريب تفاعلى؛ حتى يستطيع فى المكتبات التى يعمل بها تقديم خدمات بكفاءة وفاعلية، ومن ثم تتحقق رسالة المكتبات بفاعلية .

ولذلك نؤكد أن أهم أساسيات تقديم الخدمة المعلو ماتية وخدمة المستفيدين فى أية مؤسسة أو كيان هو تنمية المو ارد البشرية بهذا الكيان المتنامى لمساعدته على تحقيق رسالة المؤسسة، وتقديم خدمات بأعلى مستوى من الكفاءة والفاعلية، وتحقيق التو اصل الفعال مع المستفيدين فى ظل ضغوط العمل والإحباطات المتنامية والصعوبات التى تو اجه الجميع، ولذلك تم القيام بإعداد خطة مئس

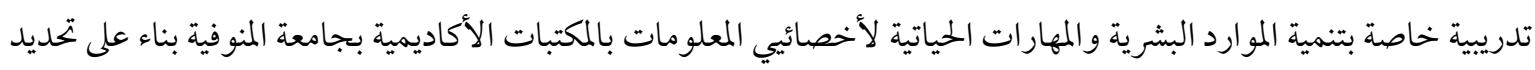
الاحتياجات التدريبية الفعلية لهم عن طريق تحليل استبيان وزع عليهم، وسوف نعرض الخطة فى هذا الجزء من الدراسة.

1- أهداف الخطة التدريبية:

هو تأهيل أخصائي المعلومات لكى يتغلب على الصعوبات التى تواجهه في مكتبته ومساعدته من أجل تقديم خدمات أفضل بفاعلية وتميز، ومن ثم خدمة المجتمع المحيط في إطار منظومة التنافس وجودة الأداء والخدمات المتميزة المقدمة للمستفيدين، ومن ثم تحقيق أعلى مستوى من رضا المستفيدين عن الخدمات التى تقدمها المكتبة.

2-الجمهور المستهدف من الخطة التدريبية:

الجمهور المستهدف من هذه الدورات هم أخصائيو المعلومات بالمكتبات الأكاديمية بجامعة المنوفية.

\section{3-المحتوى التدريبى فى الخطة التدريبية:}

سيتعرف المتدربون فى هذا البرنامج التدريبى على المعارف والمهارات والاتجاهات الإيجابية اللازمة لكيفية الوصول إلى تحقيق رسالة المكتبة بفاعلية وكفاءة بها يخدم المستفيدين في البيئة المحيطة والمجتمع، وكيفية إدارة الذات والوصول للنجاح بكفاءة و مهارة وفاعلية بها يفيد تقديم خدمات معلو ماتية على أعلى مستوى من الكفاءة والفاعلية للمستفيدين بصورة إيجابية تفاعلية تحدم

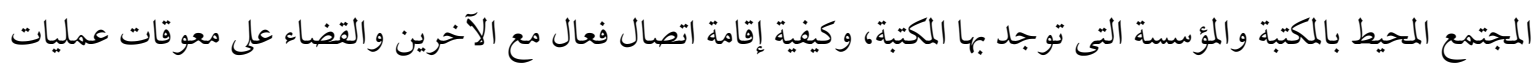

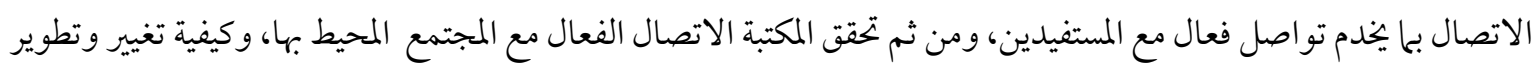
مهار اتهم فى مجال إدارة الوقت والتغلب على ضغوط العمل بكفاءة ومهارة؛ لتقديم الخدمات المعلوماتية بكفاءة وتحقيق الإفادة القصوى من الوقت و إدارته وساعات تقديم الخدمة المكتبية والمعلوماتية بأعلى مستوى من الفاعلية، وكيفية التأثير على الآخرين ووضع البصمة الشخصية الإيجابية، ومن ثم يصبح أخصائي المعلومات ذا تأثير إيمابى على المستفيدين، وتصبح المكتبة ذات تأثير إيجابى يجذب المستفيدين والمجتمع المحيط بطريقة فعالة، وكيفية تطوير الذات عند أخصائي المعلو مات وتقبل 
التغيير ومواكبة سوق العمل والمستجدات المستحدثة، وكيفية فتح صندوق العقل والخروج عن التفكير التقليدى، وفتح الطريق للتفكير والإبداع فى تقديم الخدمات المعلوماتية، وكيفية جذب المستفيدين إلى المكتبة، وكيفية إعداد خطط تسويقية

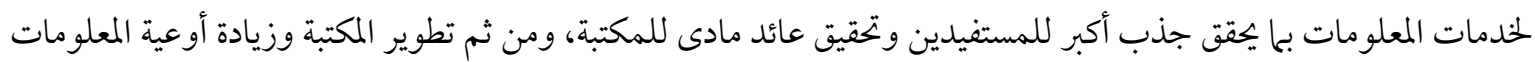
بها، وكيفية تحول أخصائي المعلومات التقليدى لأخصائي متميز ينشر السعادة عند تقديم الخدمات المعلوماتية، ويحاول أن يتو اصل بايجابية مع المستفيدين ويسيطر على ما بداخله من غضب، وكيفية استخدام مهارات غير تقليدية لتقديم خدمات معلومات على درجة كبيرة من الجودة والتميز، وبعد أن يكتسب أخصائي المعلومات كل هذه المعلو مات والمهارات واتهات والاتجاهات يصبح ذا بصمة إيجابية فى مكتبته وعلى الآخرين، ومن ثم تحقق المكتبة رسالتها فى خدمة المحيطين بها، وتصبح المكتبة أكثر تميزا وتحتل الصدارة فى

\begin{tabular}{|c|c|c|c|c|c|}
\hline والنتائج المتوقعة & أهداف البرنامج & التوقيت & الجهه المسئولة عن & الفئة المستهدفة & اسم البرنامج التدريبي \\
\hline 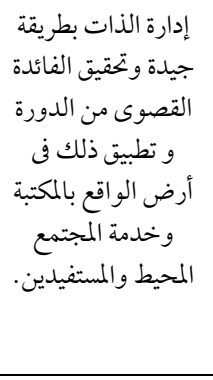 & 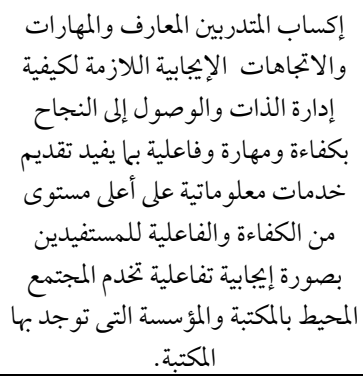 & لمدة 6 ساعات & 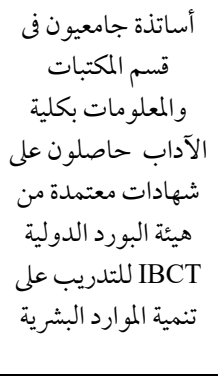 & 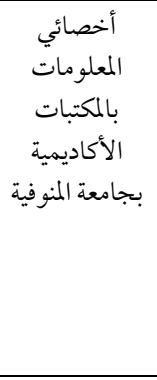 & 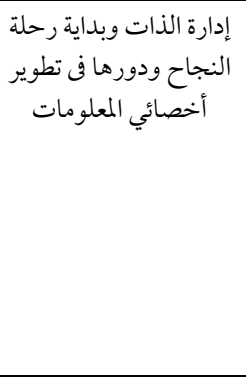 \\
\hline 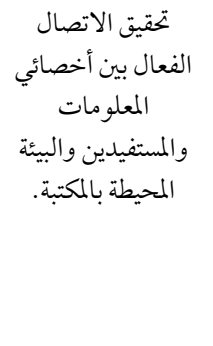 & 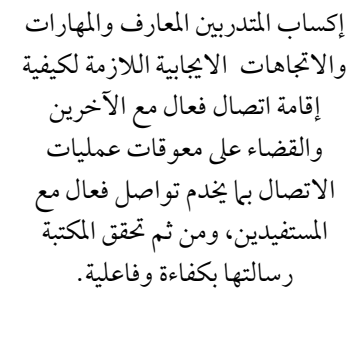 & لمدة 18 ساعة أيام & 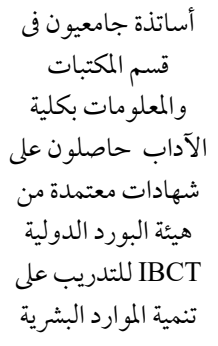 & بالمالمكتبات & ومعار و وتخات الاتصماتية الاتصال الفعال \\
\hline 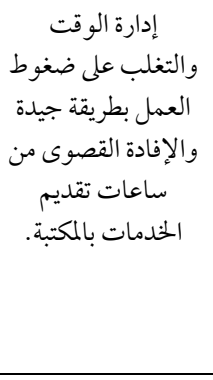 & 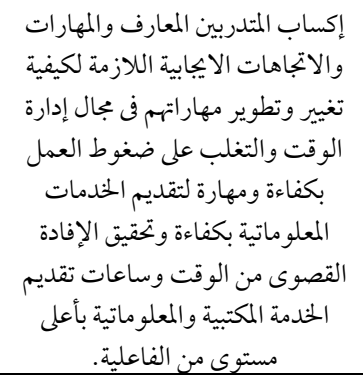 & لمدة 18 ساعة أيام & 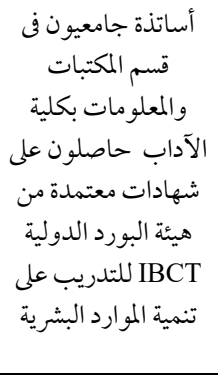 & بالمالمكتبات الخصاتئي & 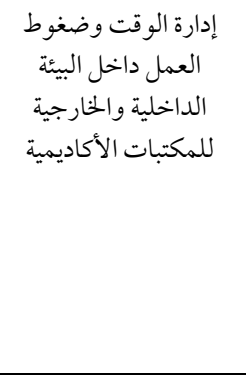 \\
\hline 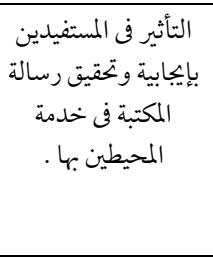 & 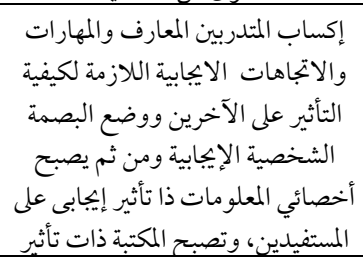 & لمدة 18 ساعة أيامة & 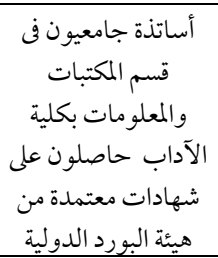 & 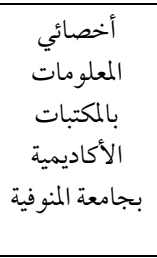 & 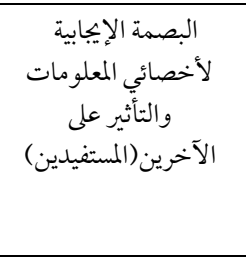 \\
\hline
\end{tabular}




\begin{tabular}{|c|c|c|c|c|c|}
\hline ومؤشرائت المتوقعاح & أهداف البرنامج & التوقيت & الجهه المسئولة عن & الفئة المستهدفة & اسم البرنامج التدريبي \\
\hline & 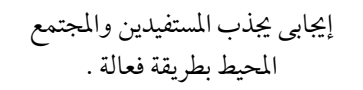 & & 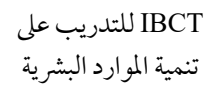 & & \\
\hline 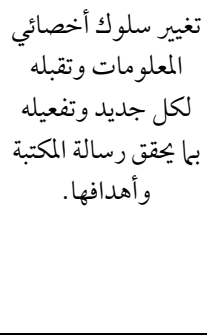 & 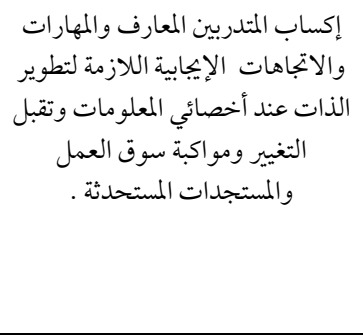 & لمثلاثة أيام 18 ساعة & 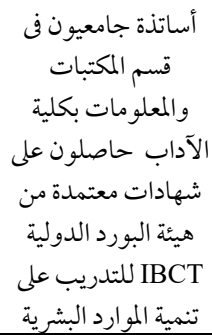 & 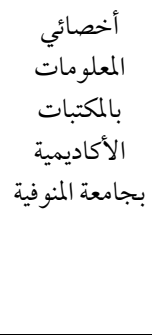 & 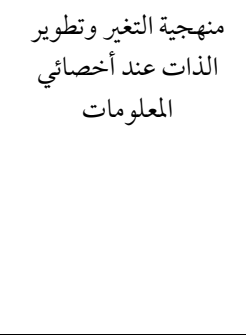 \\
\hline 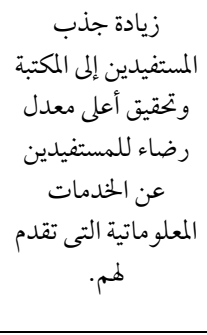 & 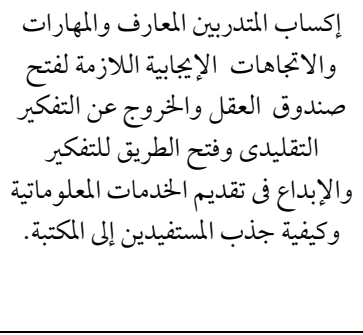 & لمدة 24 ساعة أيامة & 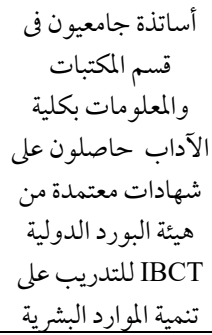 & 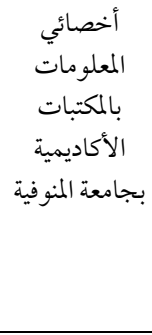 & التفكير الإبداعى في تقديم \\
\hline 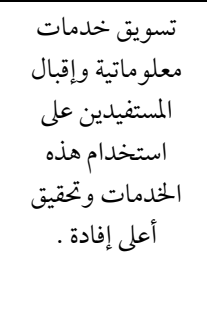 & 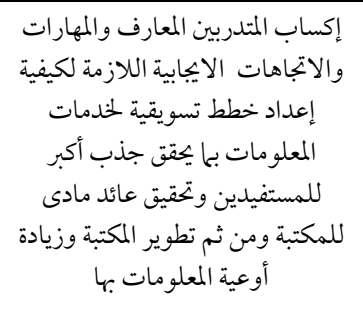 & لمدة 24 ساعة أربام & 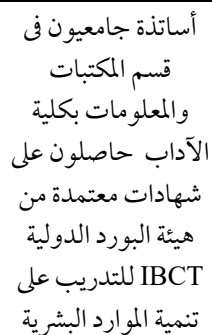 & 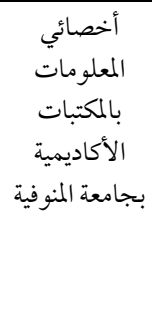 & التسويق المعلوماتى المعاتى لأخصائي \\
\hline 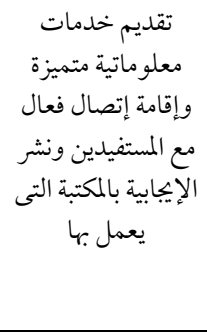 & 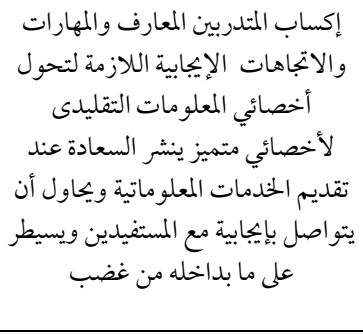 & لمدة 6 سماعات & 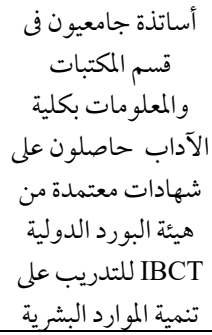 & 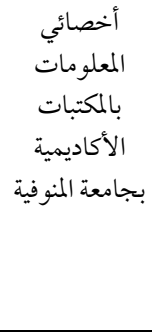 & أخصائي المعلومات السعادة عند \\
\hline 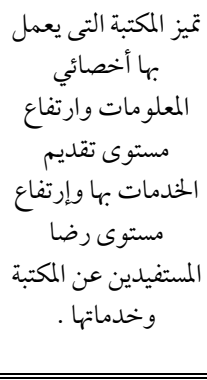 & 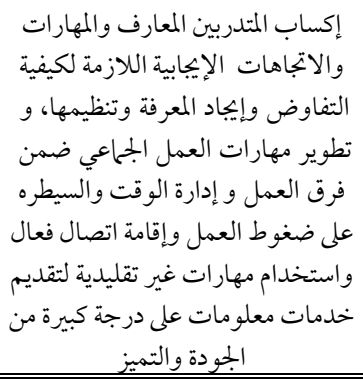 & لمدة 24 ساعة أيامة & 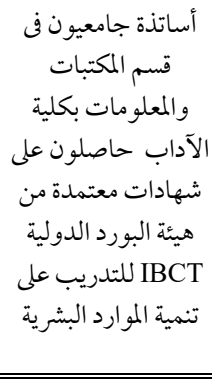 & 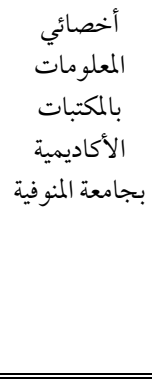 & المهار جودة الخياتية ودورهات \\
\hline
\end{tabular}

\section{4- طرق وأساليب التدريب :}

وفى إطار تحديد طرق وأساليب التدريب التى سوف يستخدمها القائم بالتدريب فى الدورات التدريبية الخاصة بتنمية

الموارد البشرية الخاصة بالخطة التدريبة نجد أنها سوف تتنوع بين جماعات نقاش، وورش العمل، والعصف الذهنى، ودراسة 
الحالة، والمحاضر ات، وفكر ثم شارك ثم ناقش TPS، و التحدث عن القصة، ولعب الأدوار، و التكليفات، والمحاكاة، والمناظرة، لكى يستطيع المدرب إكساب المتدربين كافة أنواع المعلومات والمهارات ويستطيع أن يغير اتجاهاتهم .

5-1المدرب:

توفير المدرب الكفء يمثل عاملا من العوامل الرئيسية التي تعطي مؤشرا مسبقا على نجاح البرامج التدريبية التدريبية ويجب أن يلم المدرب بمختلف الجو انب المتصلة بالعمل الذي يدرب الأفراد عليه ، وأن يكون مؤهلا لذلك، وبشكل عام هناك

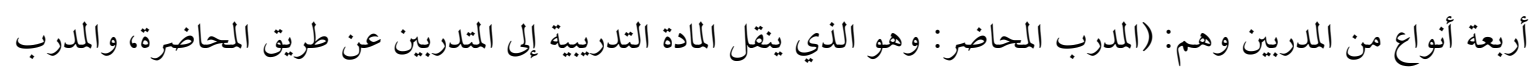
القائد: وهو الذي يقدم الجلسة التدريبية فيتولى تدريب مجموعة من الأفراد من خلال قيادته للجلسة، والمدرب التطبيقي: وهو الذي لديه الخبرة العملية إلى جانب الخبرة النظرية، والمدرب النفسي: ويقصد به الشخص الذي لديه الخبرة والمعرفة بالعلوم

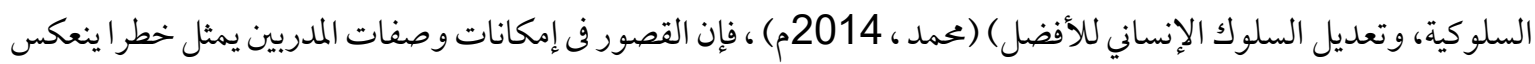
على مستوى التدريب و المتدربين

.( Sandford, 2002.)

ويمكن إضافة نوع آخر من المدربين وهو المدرب التفاعلى: وهو الملم بكل جو انب الموضوع النظرية والتطبيقية، ويستطيع

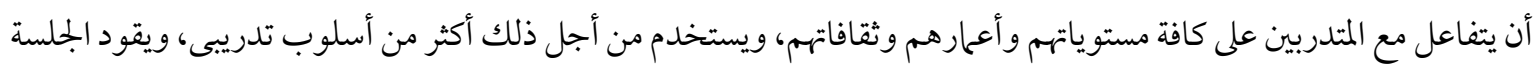

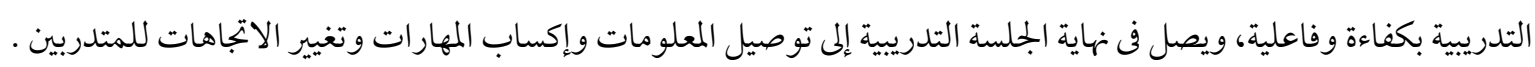

\section{نتائج الدراسةة:}

لأن تحديد الاحتياجات التدريبية الخاصة بالمهارات الحياتية لدى أخصائي المعلومات من الموضوعات المهمة التى تنتمى لمجال تنمية الموارد البشرية، أفردنا هذه الدراسة لقياس ذلك، وكذلك وضع خطة مستقبلية من أجل الاهتحام بأخصائي المعلومات فى المكتبات الجامعية ورفع كفاءته وإنتاجيته، ومن ثم تتحسن الخدمات التى تقدمها المكتبات الجامعية، ويصبح المستفيدون على أقصى درجات الرضا عن كل ما يقدم لهم، ومن أجل ذلك نستعرض النتائج التى تم التوصل إليها في النقاط الآتية:

\section{أولا: النتائج الخاصة بالمهلومهات الشخصية:}

- أظهرت الدراسة أن عينة الدراسة تشمل 63 فردا من الذكور بنسبة 36٪ ، بينما 112 من الإناث بنسبة 64٪.

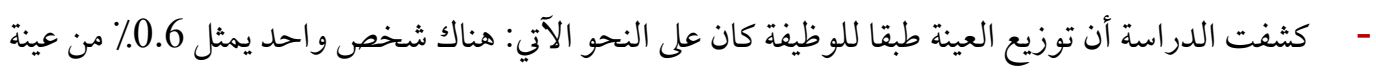

الدراسة يعمل في وظيفة مدير عام مكتبات، و كذلك شخص واحد يمثل 0.6٪ من عينة الدراسة يعمل في

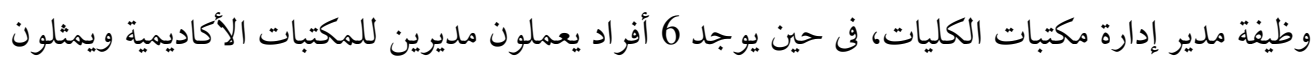

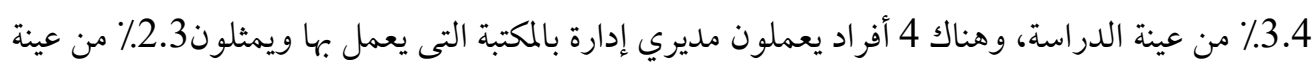

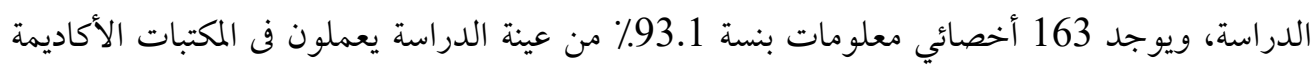

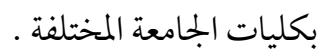

كشفت الدراسة أن توزيع العينة طبقا للفئة العمرية كان على النحو الآتي: فى المرتبة الأولى الفئة العمرية من 30-

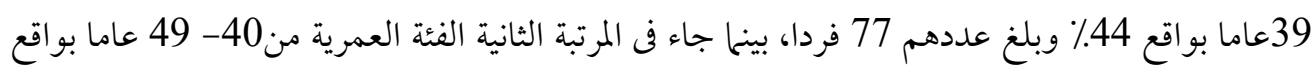




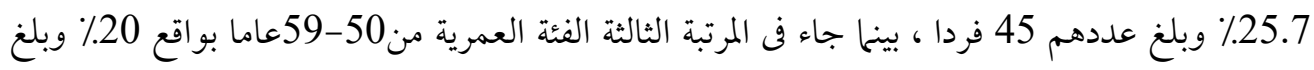

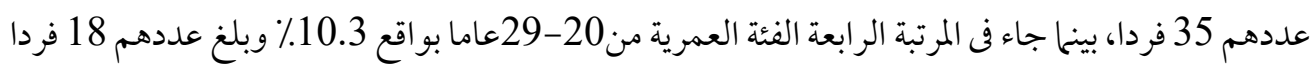

- أظهرت الدراسة أن توزيع العينة وفقا للمؤهل الدراسى جاء على النحو الآتي: فى المرتبة الأولى الحاصلون على

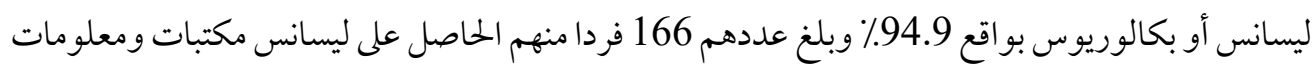
وكذلك ليسانس لغة إنجليزية، وليسانس علم اجتماع، وليسانس لغة عربية، وليسانس لغة ألمانية، وليسانس

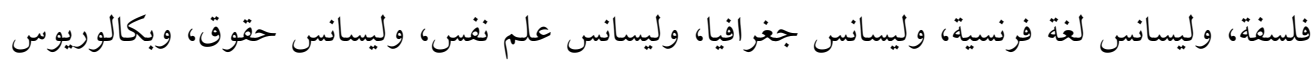

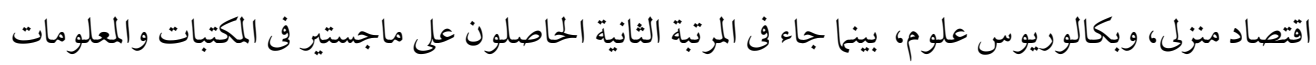

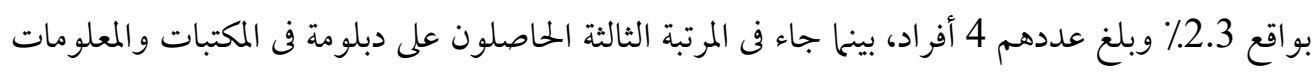

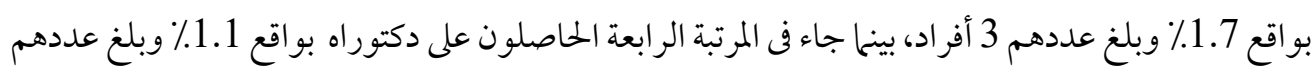
فردين

\section{ثانيا/ هملوهات عاهة عن البراهج التدريبية التى تم الهصول عليها هن قبل:}

كشفت الدراسة أن عينة الدراسة كلها 175 أخصائي معلومات فى المكتبات الأكاديمية بجامعة المنوفية قد

$$
\text { حصلو اعلى دورات تدريبية أثناء العمل . }
$$

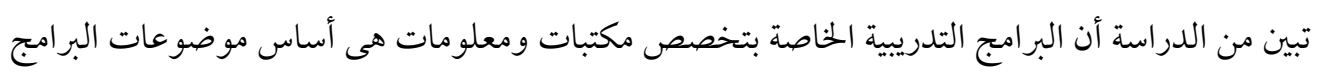

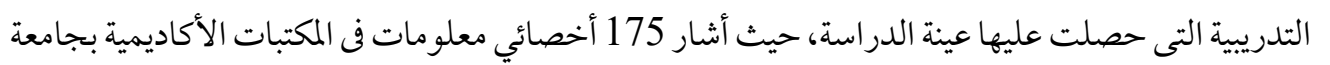
المنوفية بنسبة 100٪ إلى ذلك، فى حين أشار 20 أخصائي معلومات بنسبة 1.4 1. بأن البرامج التدريبية الخاصة بتنمية الموارد البشرية والمهارات الحياتية من ضمن موضوعات البرامج التدريبية التى حصلوا عليها أثناء

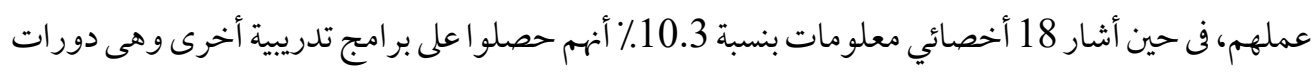
عن استخدام بنك المعرفة المصرى، وعن برنامج المستقبل لإدارة المكتبات FLS، ودورة تصميم مواقع، ودورة صيانة حاسب آلى، ودورات قيادة حاسب آلى ICDL، ودورات في اللغة الإنجليزية .

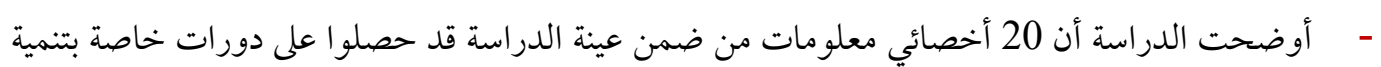
الموارد البشرية والمهارات الحياتية دورات فى مهارات الاتصال الفعال، وتنمية المهارات القيادية والإشرافية

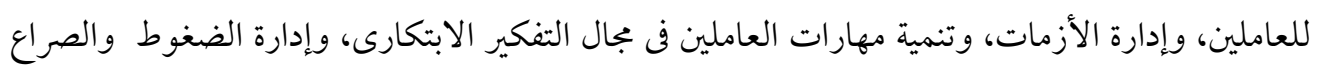

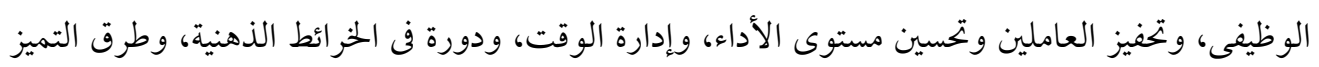

$$
\text { و التحدى. }
$$

كشفت الدراسة أن 18 فردا من 20 أخصائي معلومات الذين حصلوا على دورات خاصة بتنمية الموارد البشرية و المهارات الحياتية حققوا بنسبة 90٪ الإفادة من دورات تنمية الموارد البشرية والمهارات الحياتية التى حصلوا

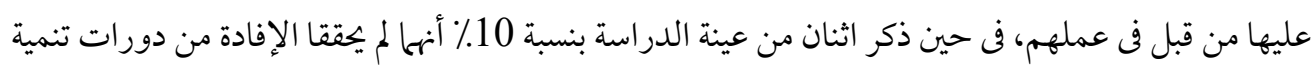

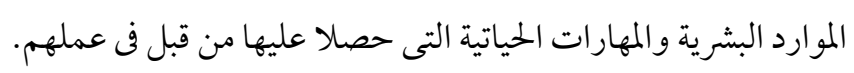




\section{ثالثا / أهداف البراهج التدريبية التى تم المصول عليها وهزاياها:}

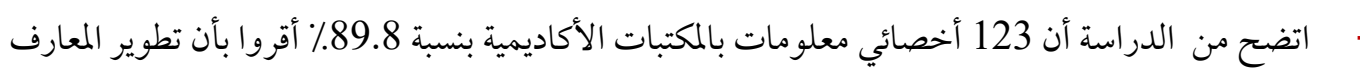

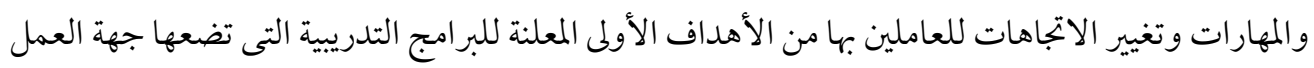

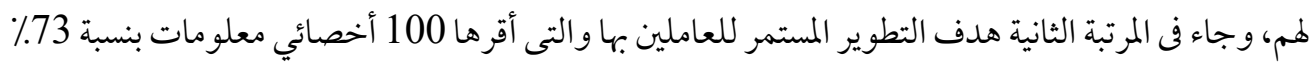

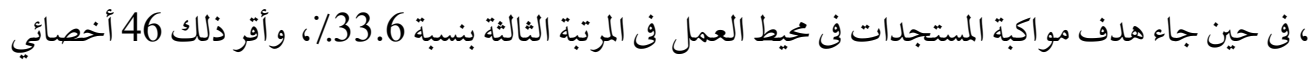

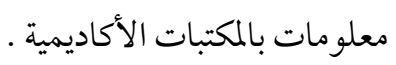

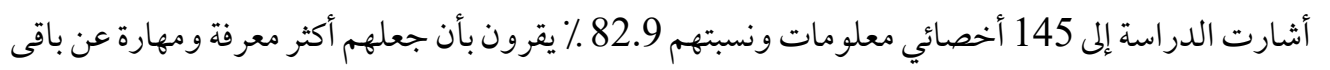

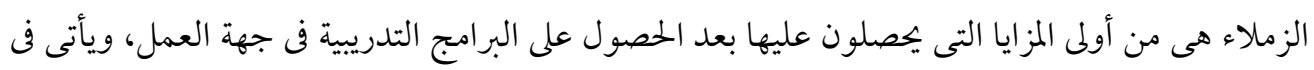

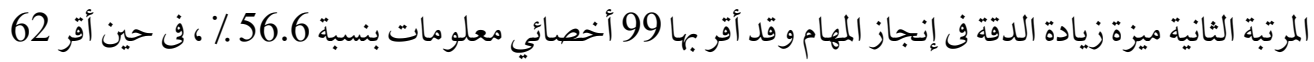

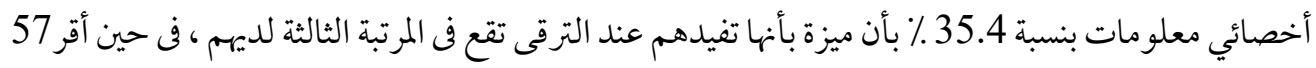

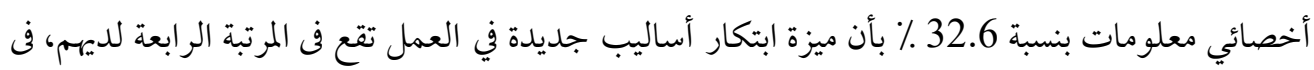

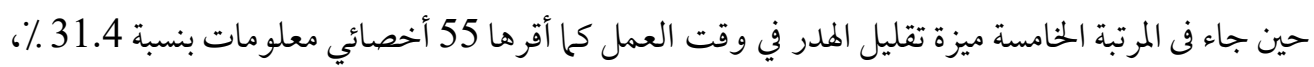

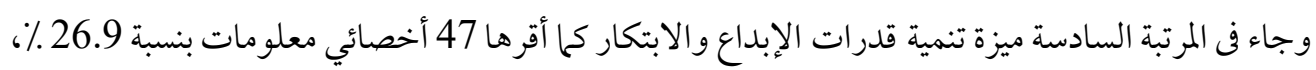

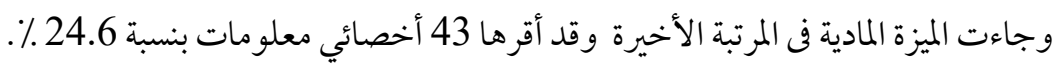

\section{رابعا/ هدى الإفادة هن البراهج التدريبية التى حصلت عليها عينة الدراسة:}

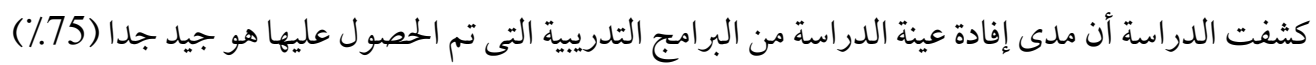

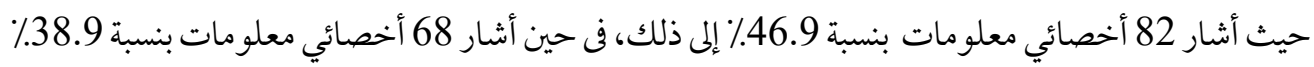

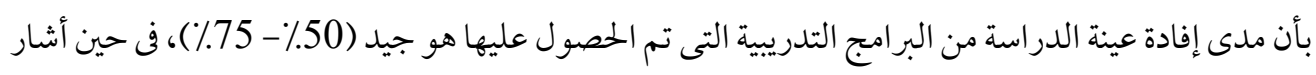

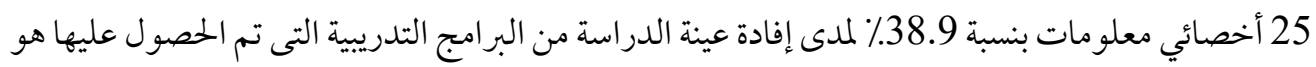
متتاز (100). (100).

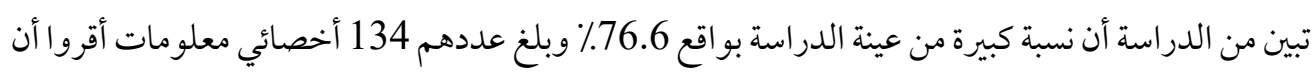

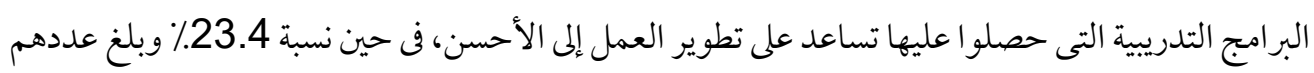

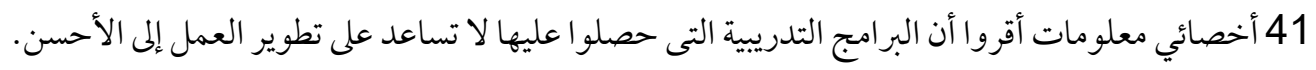

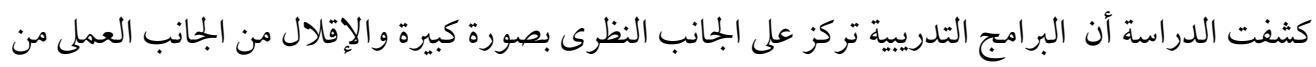

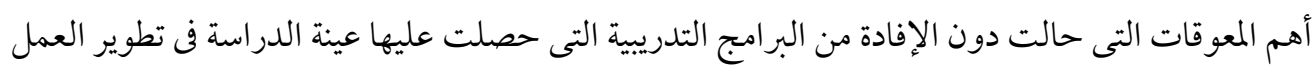

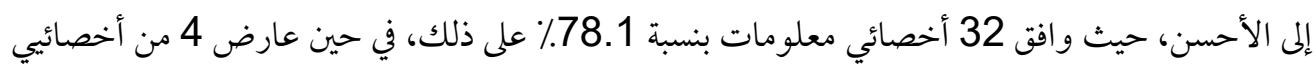

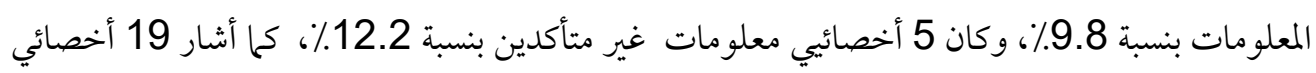

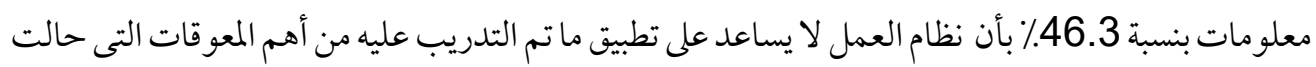

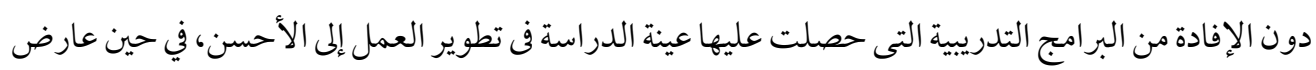

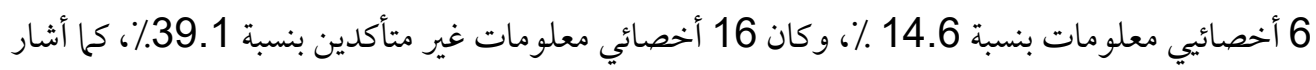

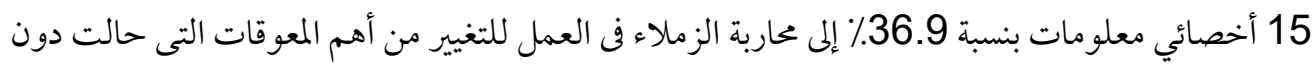




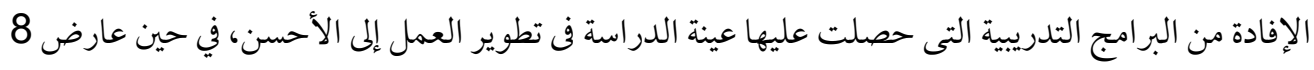

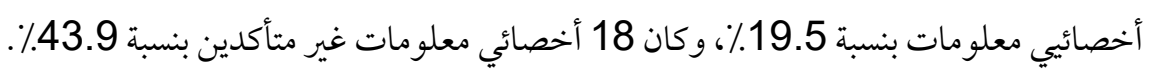

\section{خامسا/ الاحتياجات التدريبية المستقبلية الخاصة بتنمية الموارد البشرية:}

- أشارت الدراسة إلى 163 أخصائي معلومات بنسبة 93.1٪ أقروا بأن الدورات التدريبة الخاصة بتنمية الموارد البشرية تسهم في رفع الجمارات: ( القدرات المعرفية والمهارية والاتجاهات ) الخاصة بهم فى بجال العمل، فى حين

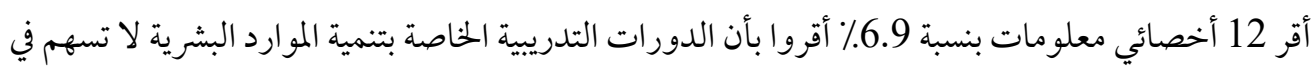
رفع الجمارات: ( القدرات المعرفية والمهارية والإتجاهات) الخاصة بهم في مجال العمل.

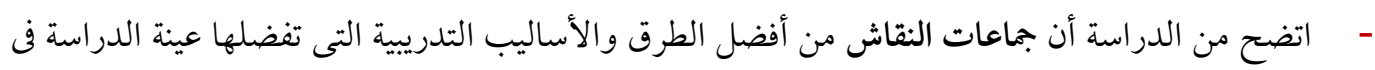
الدورات التدريبية الخاصة بتنمية الموارد البشرية التى يرغبون فى الحصول عليها، حيث و افق التقات 151 أخصائي

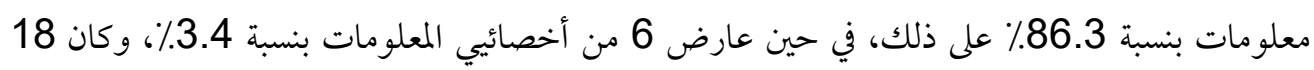
أخصائي معلومات غير متأكدين بنسبة 10.3. 10. - أظهرت الدراسة أن 144 أخصائي معلومات ونسبتهم 82.3٪ يقرون بأن من أهم الطرق التى ترغبها عينة الدراسة لتقييم أدائها أثناء الحصول على الدورات التدريبية الخاصة بتنمية الموارد البشرية هى التكليفات و الأبحاث.

\section{توصيات الدراسة :}

وبناء على النتائج التى توصلت إليها هذه الدراسة يمكن الخروج بمجموعة من التوصيات والمقترحات التى تسهم فى

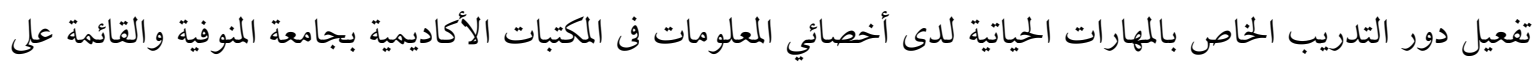

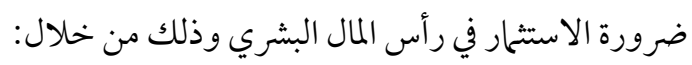
- - تنمية الوعى بأهمية تحديد وتحقيق الأهداف التدريبة، وتحديد الاحتياجات التدريبية لأخصائي المعلومات

$$
\text { و العمل على تحديد هذه الاحتياجات بشكل دوري . }
$$

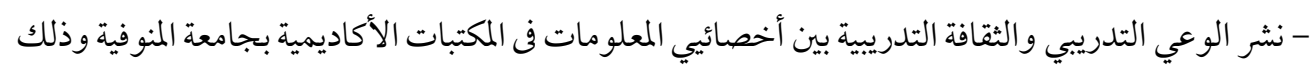
من خلال نشر وإتاحة سياسات التدريب وتعريف الجميع بها . - تخصيص ميز انية كافية لنشاط التدريب؛ لضمان استمرارية الدورات الخاصة بالمهارات الحياتية لدى أخصائيي المعلومات فى المكتبات الأكاديمية بجامعة المنوفية. - ربط التدريب بالتقييم السنوي الفعلي لأخصائي المعلومات فى المكتبات الأكاديمية، وهذا من شأنه أن يزيد من أثر التدريب؛ فمن خلال التقييم السنوي يمكن الوقوف على نقاط ضعف الموظف وتحديد المبن احتياجاته، ومن ثم وضع الخطة التقويمية بـا يتفق مع الحاجة.

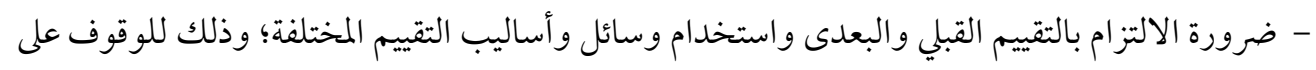
الجانب السلبي وتقويمه فور حدوثه وتفادي حدوثه فيها بعد، بالإضافة إلى تعزيز الجانب الإيجابي. 
- التنويع في استخدام أساليب وطرق تدريبية تفاعلية ترتكز على تنمية المهارات، وتعديل السلوك والاتجاهات

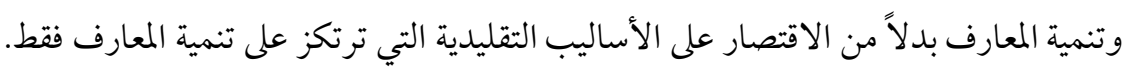

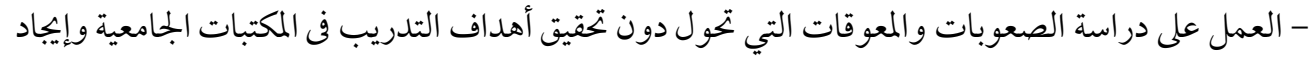

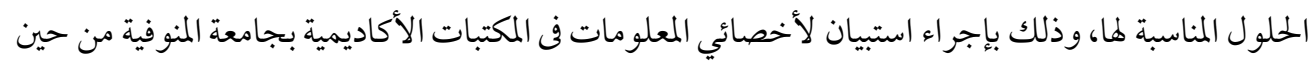

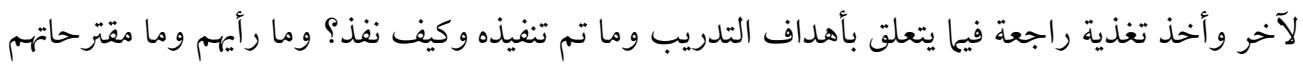

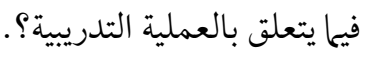

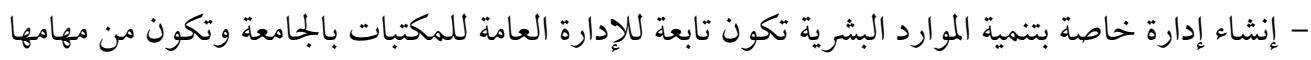

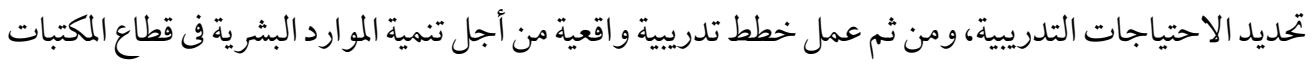

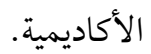

\section{قائمة المادر}

إبراهيم ، درة عبد البارى (2003)، تكنولوجيا الأداء البشرى فى المنظمات: الأسس النظرية ودلالاتها العربية،

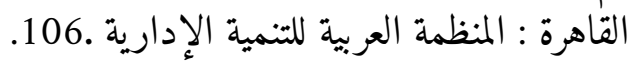

أبو غليون ، جمال صالح محمد (2010)، تحديد الاحتياجات التدريبية، المؤتمر العربي الثاني اتمنية الموارد البشرية

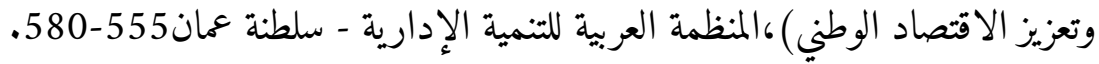

الأكلى ، عايض شافى (2012)، دور التدريب في إحداث التغيير في المنظمات العامة الحكومية، مجلة النهضة,هج .132-101، (2) 13

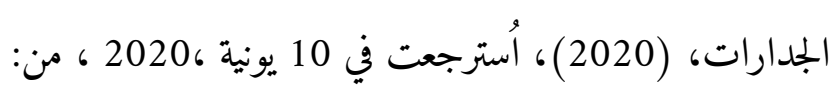
https://portal.fa.org.sa/Competences/Pages/CompetencesDefinition.asp

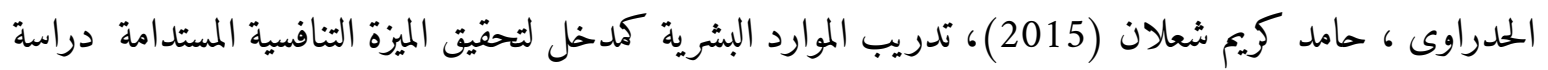

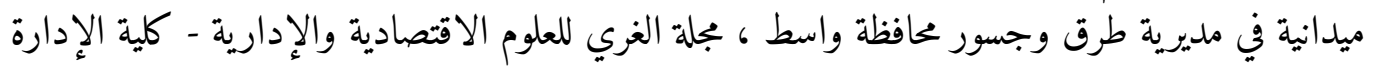
والاقتصاد - جامعة الكوفة- العراق.2 (33)، 222-242.

الرحيل، إنعام عمر عبدالله (2014)، واقع براجج تدريب العاملين في المكتبات العامة الأردنية وتقدير احتياجاتهم

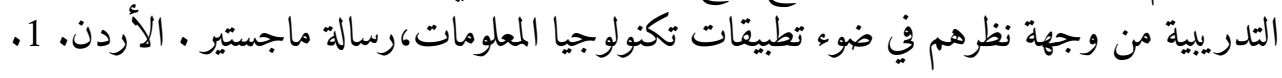

الرويلي، موافق فواز (2000)، برناجج مقترح لتدريب العاملين أثناء الخدمة،مجلةكلية التربية ، 11 (26)، 30-45.

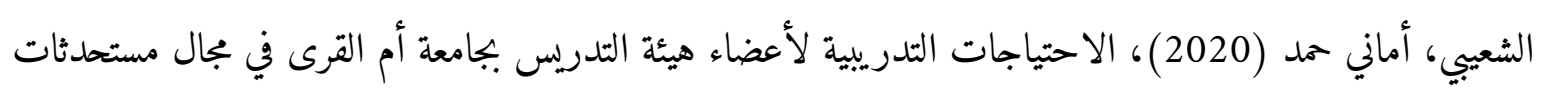

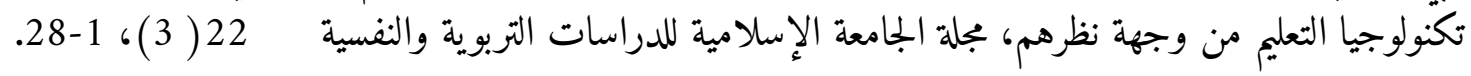
الصيرفى ، عبد الفتاح (2009) ، التدريب الإدارى: المدربون والمتدربون وأساليب التدريب، القاهرة : دار المناهج اللنشر والتوزيع • 34. 
الفارس ، سليمان خليل (2003)، إدارة الموارد البشرية (( الأفراد))،منشورات جامعة دمشق.186. الفضالة ، فهد يوسف (2015) ،التدريب وبناء السلوك المهنى، مجلة جسر التنمية بالكويت ، 13 (1) 2-13.

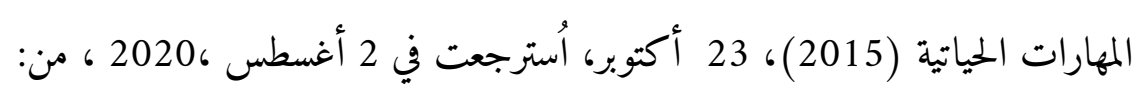
https://sites.google.com/a/elzahraa.tzafonet.org.il/mharat/z النجفى،سالم توفيق (2001)، التنمية البشرية والنمو الاقتصادى :دراسة تحليلية، بحوث اقتصادية عربية 10 (26) .78,

أهمية التدريب والدورات التدريبية في المؤسسات (2016)، 16 - مارس. أُسترجعت في 3 أغسطس ، 2020 ،

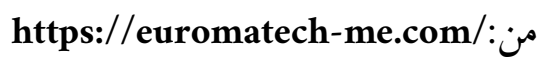
برناجج تدريب المدربين :المدرب المشارك ( 2016)، أسترجعت في 10 أغسطس 2020 ، من http://www.ibct-mena.com

بلال، خلف سكارنة (2009) ، التدريب الإدارى، عمان : دار وائل للنشر والتوزيع • 270.

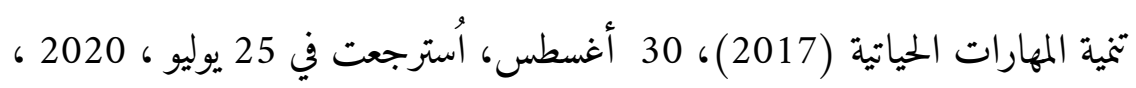
http://mawdoo3.com/ من

توفيق ، عبد الرممن (2009) ،تحديد الاحتياجات التدريبية، القاهرة : مكز الخبرات المهنية ـ 29 . حمداوى ،وسيلة (2004) ،إدارة الموارد البشرية، عمان : دار وائل للنشر والتوزيع • 25.

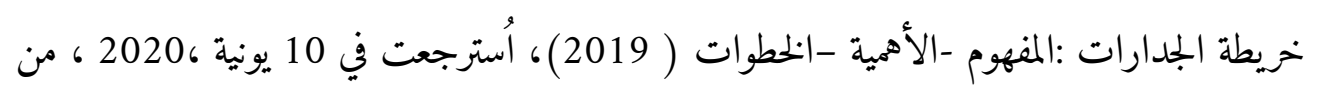
https://webcache.googleusercontent.com/

دليل المدرب (2014)، 12 مارس، أسترجعت في 12 مايو ، 2020 ، من: http://www.fao.org/wairdocs/af196a/af196a05.htm

سلطان ، محمد (2009)، إدارة الموارد البشرية، الإسكندرية : دار الجامعة الجديدة للنشر .198. شعلان ، حامد كريم (2015م)، تدريب الموارد البشرية كمدخل لتحقيق الميزة التنافسية المستدامة : دراسة ميدانية

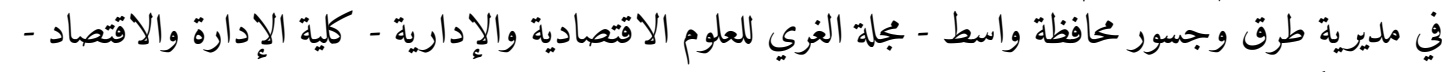
جامعة الكوفة- العراق 12 (33). 232.

عباس ، سهيلة محمد (2003) ،إدارة الموارد البشرية، عمان : دار وائل للنشر. 187 ـ

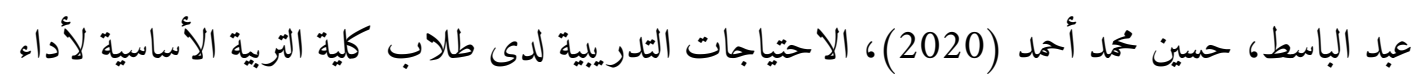

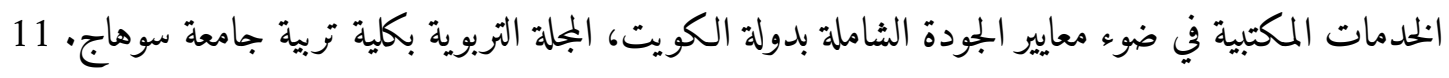


عبد الله 6 سعد الدين خليل (2007)، إدارة مراكز التدريب، القاهرة : بمحوعة النيل العربية للنشر والتوزيع • 159. عبد الله كنوال محمد (2002)، الاحتياجات التدريبية لأخصائي مكتبات الأطفال العامة، مجلة عالم المعلومات والمكتبات والنشر , جم 3 , ع ع (يوليو) , 85.

عبد المعطى، حسن الباتع محمد (2001)، برنامج مقترح لتدريب المعيدين والمدرسين المساعدين بكلية التربية

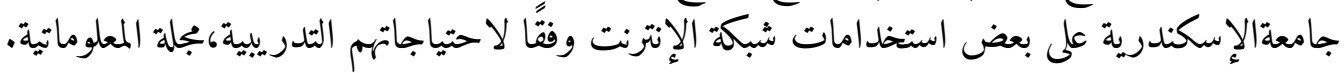
$.41-236(21) 10$

عساف، معتز عبد القادر (2008) ، التميز في إدارة الموارد البشرية، منشورات اتحاد المصارف العربية. 13 .

على ، امتثال محمد (2014)، تدريب العاملين فن المكتبات المحوسبة وأثره على فاعلية خدمات النظم الآلية

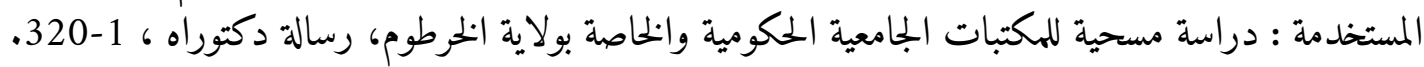
عمر ، أيمن على (2013)، تقييم أثر التدريب على تنمية الموارد البشرية: دراسة تطبيقية على جامعة الإسكندرية ، مجلة

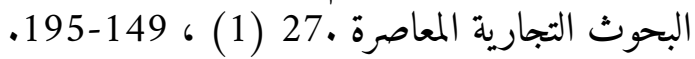

فالح ، صالح محد (2114) كإدارة الموارد البشرية ، عمان : حامد للنشر والتوزيع • 111 .

قرمش ، زهرة سعد (2017) الالتزام بتطبيق عملية تقييم البراجج التدريبية وعلاقتها بأداء وسلوك الموارد البشرية

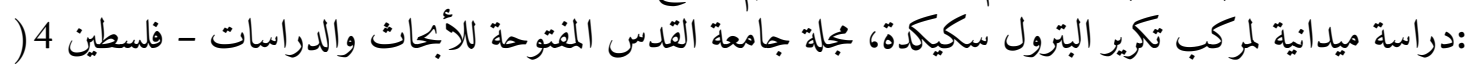
$.190-171$ ( 41

محمد ، مهنة نصيرة (2014)، تدريب العاملين في المكتبات ومراكز المعلومات، المجلة الأردنية للمكتبات والمعلومات -جمعية المكتبات والمعلومات الأردنية - الأردن

محيرق 6 مبروكة عمر (2001) ، الإعداد المهني للعاملين بجال المعلومات والمكتبات عبر الفضاء الإلكتروني، مرجع سابق •91 -96.

هارات الحياة هدفها, أهميتها, ماهي ؟ (2016)، 11 أغسطس، أُسترجعت في 20 يوليو ، 2020 ك من: http://amal.unlimitedboard.com/t4720-topic

هلابیى، منال مبارك (2020)، البيئة الجامعية وعلاقتها بالمهارات الحياتية لدى طالبات كلية التربية بجامعة

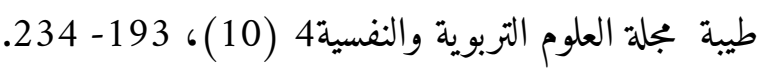

هلال ، محمد عبد الغنى حسن (2010)، أسس ومبادئ التدريب: التدريب وتنمية الموارد البشرية، القاهرة : مركز تطوير الآداء والتنمية. 23 .

Abdelgadir N and Abdelhafiz Elbadri (2001) . Training Practices of Polish Banks: An Appraisal and Agenda for Improvement. Journal of European Industrial Training,(25),75-89. 
Al - Athari, A, and Zairi, M (2002). Training evaluation: an empirical study in Kuwait.Journal of European Industrial Training, Vol. 26, No5, 241 - 251.

Cavallari, Renie (2007) .Been there, Done that, Now what? Leadership Excellence, ( 24) 4, 18-30.

Jacintha, U. Eze (2012) Staff Training Programmes in Nigerian Public Libraries: The Case of nugu State Public Library,”. Library Philosophy and Practice, 1-10.

Shali, Zhang (2014).Astudy of The job training needs of The support staff in six Kansas Board of Regents University Libraries.PHD, 1-357.

Gizem, Erdem (2019). The professional experiences and training needs of probation officers in Turkey. Journal of Social Work, ( 19) 5, $664-686$.

Dressier, Garry (2004). Human Resource Management.. Florida International University ,.59.

Donald, L. Kirkpatrick \& James D. Kirkpatrick (2011). Evaluating Training Programs. Training Reference bookshop .71.

Dale ,S. Beach (2003)The Management of People at Work, 3rd.ed. New York: McMillan, 372.

Mondy, R. Wayne, Robert M, Noe, \& Premeaut, Shane R (2002). Human Resource Management. 8th.ed. Prentice Hall, USA, 223.

Sandford, Borins(2002).Trends in Training Public Managers. International Public Management Journal (2) 2. $299-314$. 


\title{
Map of the Training Competencies
}

\author{
of Life Skills for the Information Specialist at Menoufia University: \\ a Study of the Reality and Planning for the Future
}

\author{
Dr. Noha Mohammed Othman \\ Ass. Prof. Library and Information Sciences \\ Faculty of Arts - Menofia. University (Egypt) \\ braanoha@yahoo.com
}

This study aims to know a map of the training competencies of life skills at the information specialist at Menoufia University, where the study was applied to 175 information specialists, and the descriptive analytical field approach was used as it is the most appropriate research method for this study, and the questionnaire was used as a tool to collect data related to the study with the aim of knowing general information On the training programs previously obtained by the study sample, the objectives of the training programs obtained by the study sample and their advantages, the extent of benefit from the training programs obtained, and the future training needs for human resource development, and in the end a realistic future plan was developed based on the identification of needs Training and training competencies map for the sample of the study, and among the most important results of the study is that 163 information specialists, by $93.1 \%$, admitted that training courses for human resource development contribute to raising the competencies (knowledge, skills and attitudes) of them in the field of work, while 12 information specialists approved a percentage of $6.9 \%$ of respondents acknowledged that training courses for human resources development do not contribute to raising Competencies (cognitive, skill and attitudes) of their own in the field of work..

Key Word: Map of training competencies; Life Skills; Training needs; Information specialist; Human Resource Development ; training program. 